UNIVERSIDAD NACIONAL DE LA PLATA

FACULTAD DE CIENCIAS VETERINARIAS

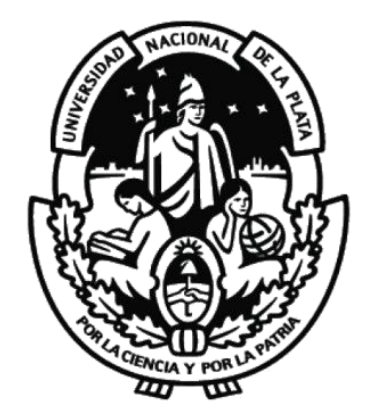

Trabajo de tesis realizado como requisito para optar el título de DOCTOR EN CIENCIAS VETERINARIAS

\title{
PÉRDIDAS REPRODUCTIVAS DE LA PREÑEZ SEGÚN EL ESTADO NUTRICIONAL MATERNO EN OVEJAS MERINO
}

\author{
Autor: Vet. BRUNO GALARRAGA, María Macarena \\ Director: MV, MSc, PhD, DECAR, DE LA SOTA, Rodolfo Luzbel \\ Codirector: Ing Agr, DrCsBiol, CUETO, Marcela Isabel
}

Director de Beca doctoral CONICET: Dra. Lacau-Mengido, Isabel Asesor: MV, PhD, Gibbons, Alejandro

Lugares de Trabajo:

Laboratorio de Reproducción de Rumiantes Menores, Estación Experimental Agropecuaria INTA Bariloche "Dr. Grenville Morris" y Campo Experimental Pilcaniyeu, INTA Bariloche

Laboratorio de Reproducción Animal, Cátedra y Servicio de Reproducción Animal, Facultad de Ciencias Veterinarias, UNLP

Laboratorio de Regulación Hipofisaria, Instituto de Biología y Medicina Experimental (IByME), CONICET

Miembros del Jurado:

DrCsNat, FURNUS, Cecilia. Instituto de Genética Veterinaria, CCT-CONICET-La Plata

MV, PhD, MEIKLE, Ana. Laboratorio de Técnicas Nucleares, FCV-UDeLaR DrCsVet, AISEN, Eduardo. Laboratorio de Teriogenología, FACA-UNComa 
Al grupo de Reproducción Animal del INTA Bariloche 


\section{AGRADECIMIENTOS}

El mayor de mis agradecimientos es para extraordinarios maestros y guías en el mundo de la investigación científica, la Dra. Marcela Cueto, el Dr. Luzbel de la Sota, la Dra. Isabel Lacau y el Dr. Alejandro Gibbons, por brindar su capacidad y experiencia científica y metodológica sin reservas, por confiar en mí, por la infinita paciencia, por siempre intentar que los progresos sean con aprendizaje y por su calidez en el trato.

Al INTA Bariloche y a su gente, un lugar de trabajo maravilloso, en el cual no existe techo para seguir creciendo profesionalmente rodeado de buena compañía. A incansables colaboradores y compañeros de trabajo, la Vet. Jimena Fernandez y el Sr. Héctor Arias que, junto a los directores de este proyecto, estuvieron codo a codo en cada ensayo.

A mis compañeros del Campo Experimental Pilcaniyeu, José María, Luciano, Martín y Rubén por los momentos de trabajo compartidos y la paciencia ante tantos muestreos en los animales.

Quiero agradecer muy especialmente a todos los que trabajan en la Cátedra y el Servicio de Reproducción Animal; por haberme brindado un lugar y una mano cuando más lo necesitaba en los primeros años del doctorado, especialmente a María, Lorena, Vanina, Vera, Alejandra y Romina. A Elías y Joaquín por su colaboración con el procesamiento del kit de AGNE.

A Ana, Damasia, Bettina y todo el equipo del Laboratorio de Regulación Hipofisaria del IBYME por su ayuda, aportes y paciencia para el procesamiento de las muestras y la medición de las hormonas metabólicas. 
A Nadia Bonadeo y Carolina Cristina del CITNOBA por su colaboración en el procesamiento de las biopsias uterinas.

A Laura V., Ariel y Nico, por la amistad y la alegría que construyen un buen ambiente de trabajo.

A mi hermosa familia, y especialmente a mi colega y compañero en esta vida, por haberme impulsado por largo tiempo a concluir esta etapa, ¡Gracias Agu! 


\section{PRÓLOGO}

La producción ovina en el norte de la Patagonia Argentina contempla principalmente sistemas de cría en condiciones extensivas estratificados en productores de baja y media escala de producción, variando la composición de las majadas entre 50 y 3000 madres. El producto de interés generado siempre ha sido la producción de lana de calidad para exportación dejando de lado la producción de corderos. Por las fluctuaciones de los mercados y precios de las fibras animales, desde hace algunos años se ha dado paso a la producción y venta de la carne como alternativa. Estos sistemas se encuentran condicionados primariamente a la oferta forrajera anual, muy fluctuante según las condiciones climáticas del año, por lo cual, muchas veces los animales están expuestos a períodos de subnutrición prolongados. Los índices productivos, evaluados especialmente a través de la tasa de señalada (número de corderos señalados sobre número de hembras a servicio), reflejan grandes pérdidas ocasionadas entre el servicio (otoño) y la señalada de los corderos (verano). Se ha estudiado que gran parte de esas pérdidas ocurre por diversos factores (estado nutricional materno, depredación, inanición, inclemencias climáticas, etc.) principalmente alrededor del parto, y se las conoce como pérdidas perinatales. Muchos estudios han reflejado que dichas pérdidas se encuentran estrechamente relacionadas con el estado nutricional materno, al obtenerse corderos de bajo peso al nacer con bajas tasas de sobrevivencia, por lo cual se han generado e implementado técnicas sencillas como la parición en potreros controlados (de menor tamaño, con reparo y elevada disponibilidad forrajera) y la suplementación estratégica preparto. Sin embargo, se carece de información sobre las pérdidas 
gestacionales en majadas ovinas patagónicas, lo cual plantea la necesidad de estudiar y cuantificar las pérdidas embrionarias y fetales y establecer su relación con el estado corporal materno al momento del servicio y durante el estadio inicial de la preñez. La difícil interpretación y extrapolación de los resultados obtenidos por otros autores en distintas razas y tipos de explotación, hace necesaria la caracterización de las pérdidas reproductivas a nivel regional, analizando en este estudio una majada en el área de Sierras y Mesetas Occidentales en la provincia de Río Negro, donde la cría ovina en condiciones de cría extensiva es la principal actividad productiva.

La implementación de la suplementación durante el preservicio puede mejorar los índices reproductivos en majadas ovinas, no existiendo datos en cuanto a qué proporción de pérdidas embrionarias y fetales podrían evitarse cuando se utiliza esta herramienta en los estadios iniciales de la preñez en ovejas con distintos estados corporales. Generar esta información nos permitirá realizar un uso racional y justificado de esta técnica, con el objetivo de alcanzar el máximo potencial reproductivo de las hembras ovinas mediante la obtención de una alta tasa de preñez y disminución de las pérdidas prenatales, para finalmente favorecer el porcentaje anual de señalada acercándose a un sistema productivo más rentable. 


\section{CONTRIBUCIÓN AL AVANCE DEL CONOCIMIENTO CIENTÍFICO}

La realización de este trabajo de tesis permitió caracterizar y cuantificar las pérdidas embrionarias y fetales en ovinos; y establecer en qué período ocurre el mayor porcentaje de pérdidas relacionadas con el estado nutricional materno, pudiendo así optimizar el uso de la suplementación estratégica en los momentos adecuados. Asimismo, estos datos nos permitirán anticiparnos frente a una baja respuesta reproductiva de los vientres ante una oferta forrajera reducida, disminuyendo el riesgo de pérdida y contribuyendo al porcentaje de señalada anual necesario para mantener la rentabilidad productiva y económica de los productores ovinos de nuestra región. 


\section{PUBLICACIONES PARCIALES DEL TRABAJO DE TESIS}

1. Bruno-Galarraga M.M, Cueto M, de la Sota RL, Lacau I, Gibbons A. 2014. Estado nutricional materno y su incidencia sobre las pérdidas embrionarias y fetales en los ovinos. Spermova 4: 10-16. p-ISSN: 22239375

2. Bruno-Galarraga M.M, Cueto M, Gibbons A, Accastello N, de la Sota RL, Lacau I. 2014. Caracterización de las pérdidas de gestación en ovejas Merino en condiciones de cría extensiva. Comunicación. $37^{\circ}$ Congr. Arg. Prod. Anim. II Joint Meeting AAPA-ASAS (American Society of Animal Science). Buenos Aires, Argentina. 20-22 octubre. Rev. Arg. Prod. Anim. 34. Supl. 1. p-ISSN: 0326-0550

3. Bruno-Galarraga M.M., Cueto M., Gibbons A., Pereyra-Bonnet F., Catalano R., Gonzalez-Bulnes A. 2014. Repeatability of superovulatory response to successive FSH treatments in Merino sheep. Small Ruminant Research 120: 84-89. ISSN: 0921-4488

4. Gibbons A, Cueto M, Bruno-Galarraga M.M, Villar L, Giraudo C. 2014. Detección de problemas reproductivos en la majada. Manual de difusión Prod. Anim. INTA-EEA-Bariloche.

5. Bruno-Galarraga M.M, Cueto M, Villar L. 2015. Servicio a corral en ovinos. Presencia 63: 54-57. ISSN: 0326-7040

6. Bruno-Galarraga M.M, Cueto M, Gibbons A, de la Sota R, Lacau I. 2015. Effect of maternal nutrition on insulin and IGF-1 during early pregnancy in sheep. $3^{\circ}$ Reunión Conjunta de las Sociedades de Biología. Tucumán. 9 al 11 septiembre. Biocell 39, 5:1-232. ISSN: 1667-5746

7. Bruno-Galarraga M.M, Cueto M, Gibbons A. Reproducción. Parte II: Avances en tecnologías reproductivas en los ovinos. En: IX Curso de Actualización en Producción Ovina. INTA-EEA Bariloche. p. 86-90. Capítulo de Libro. ISBN 978-987-521-651-8

8. Cueto M, Gibbons A, Bruno-Galarraga M.M, Fernandez J. 2015. El uso de la ecografía en el diagnóstico de gestación en ovinos. En: IX Curso de Actualización en Producción Ovina. INTA-EEA Bariloche. p. 185-189. ISBN 978-987-521-651-8

9. Bruno Galarraga M.M, Cueto M, Gibbons A, Pereyra Bonnet F., Subiabre M., Gonzalez Bulnes A. 2015. Preselection of high and low ovulatory responders in sheep multiple ovulation and embryo transfer programs. Theriogenology 84:784-790. ISSN: 0093-691X 
10. Bruno-Galarraga M.M, Cueto M, Gibbons A, Fernandez J, Lacau I, de la Sota RL. 2015. Pérdidas embrionarias y fetales en ovinos. Capítulo 51. En: Manual de Reproducción de Animales de Producción y Compañía. Libros de Cátedra de la Universidad Nacional de La Plata. ISBN 978-9-503-413814.

11. Bruno-Galarraga M.M, de la Sota R.L, Lacau I, Fernandez J, Gibbons A, Cueto M. 2016. Eficiencia de la transferencia de embriones en ovinos según las características morfológicas embrionarias. $3^{\circ}$ Congreso Sociedad Argentina de Tecnologías Embrionarias. Facultad de Agronomía-UBA.

12. Bruno-Galarraga M.M, Cueto M, Fernandez J, Gibbons A, de la Sota R.L, Lacau I. 2017. Efficiency of embryo transfer in sheep under different nutritional status of donor and recipient ewes. Reunión Conjunta de las Sociedades de Biociencias. Buenos Aires, 13-17 de noviembre. Revista Medicina (Buenos Aires) 77: Supl 1, 280. ISSN: 1031-3613

13. Bruno-Galarraga M.M, Bonadeo N, Cristina C, Alvarez L, Fernandez J, Gibbons A, de la Sota RL, Lacau I, Cueto M. 2018. Effect of restriction of maternal nutrition on embryo survival, uterine environment and embryo transfer results in sheep. International Ruminant Reproduction Symposium. 16 al 20 de septiembre, Foz de Iguazú, Brasil. Anim Reprod 15 Suppl1: 1078. ISBN: $1984-3143$ 


\section{PROYECTOS DE FINANCIAMIENTO Y CONTRIBUCIONES}

\section{INSTITUCIONALES}

Los ensayos experimentales del presente estudio se desarrollaron en el Campo Experimental Pilcaniyeu y el Laboratorio de Reproducción de Rumiantes Menores pertenecientes a la Estación Experimental Agropecuaria del INTA Bariloche, provincia de Río Negro, Argentina. El procesamiento y evaluación de las muestras se realizaron en el Laboratorio de Reproducción de Rumiantes Menores de la EEA INTA Bariloche; en el Laboratorio de Reproducción Animal de la Facultad de Ciencias Veterinarias de la UNLP y en el Laboratorio de Regulación Hipofisaria en el Instituto de Biología y Medicina Experimental (IBYME) CONICET.

El financiamiento del presente trabajo de tesis se llevó a cabo con fondos provenientes del proyecto Foncyt (PICT $2012 \mathrm{~N}^{\circ}$ 2238), el Proyecto Específico 1115053 de la cartera de proyectos INTA (2013-2019) junto a la colaboración del proyecto regional PATNOR 1281102 y el Proyecto Incentivos 11/V200 (UNLP). 


\section{ÍNDICE}

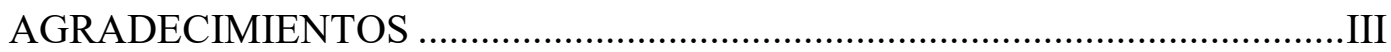

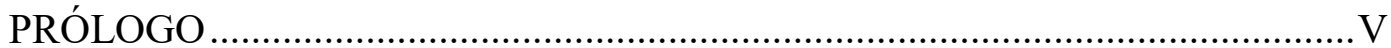

CONTRIBUCIÓN AL AVANCE DEL CONOCIMIENTO CIENTÍFICO........ VII

PUBLICACIONES PARCIALES DEL TRABAJO DE TESIS ......................... VIII

PROYECTOS DE FINANCIAMIENTO Y CONTRIBUCIONES

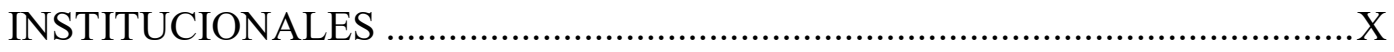

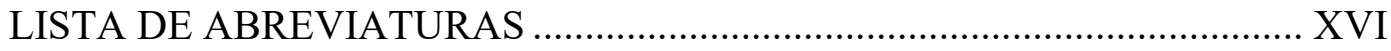

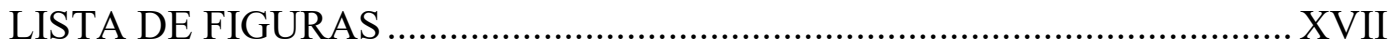

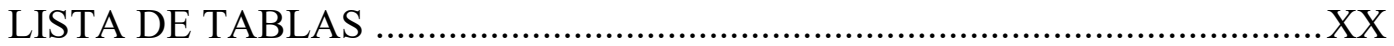

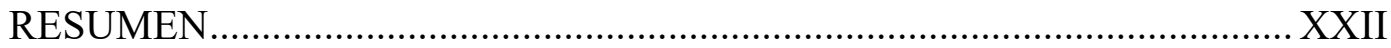

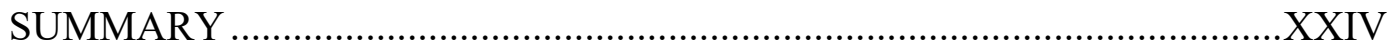

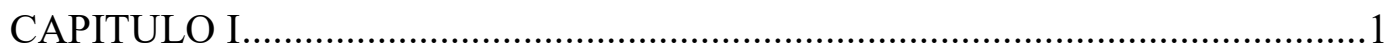

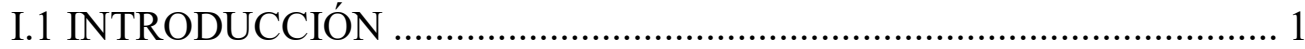

Breve descripción del sistema productivo ovino en la Patagonia

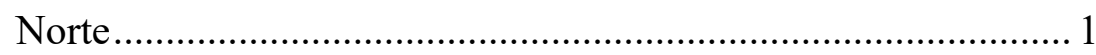

Fisiología y endocrinología del ciclo estral ovino ..................... 2

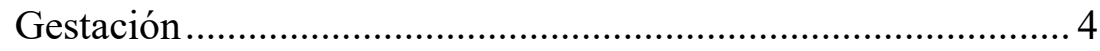

Desarrollo embrionario temprano ........................................... 4

Reconocimiento materno de la gestación ................................... 5

Pérdidas prenatales .............................................................. 7

Evaluación del estado nutricional ........................................... 8

Efecto de la nutrición sobre el eje reproductivo....................... 11

Efecto del estado nutricional materno sobre el desarrollo

embrionario y fetal ............................................................... 12

Mediadores entre el estado metabólico y el desarrollo

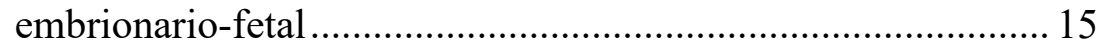

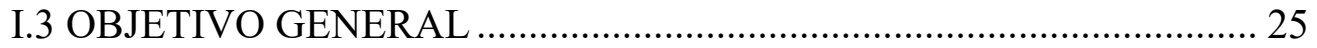

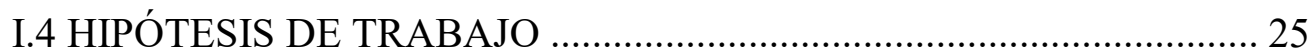


CAPITULO II .26 CARACTERIZACIÓN DE LAS PÉRDIDAS DE GESTACIÓN EN OVEJAS MERINO EN CONDICIONES DE CRIA EXTENSIVA .26

II.1 INTRODUCCIÓN 26

II.2 OBJETIVOS 27

II.3 HIPÓTESIS 27

II.4 MATERIALES Y MÉTODOS . 28

II. 4.1 Animales y lugar de trabajo ........................................... 28

II. 4.2 Condiciones de estudio y servicio a corral ..................... 29

II. 4.3 Determinación de peso vivo y condición corporal .......... 30

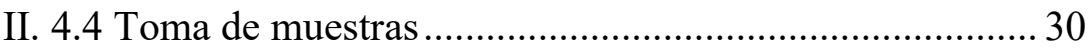

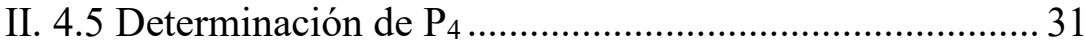

II. 4.6 Determinación de metabolitos y hormonas metabólicas 31

II. 4.7 Diagnóstico de gestación y pérdidas gestacionales ........ 32

II. 4.8 Análisis estadístico ........................................................ 33

II.5 RESULTADOS 34

II. 5.1 Sincronización de celo y servicio 34

II. 5.2 Estado corporal y edad sobre la tasa de preñez ............ 36

II.5.3 Diagnóstico de gestación y pérdidas gestacionales ....... 36

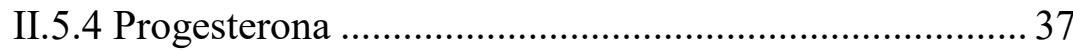

II.5.5 Metabolitos y hormonas metabólicas ........................... 39

II.6 DISCUSIÓN

Presentación de estros y tasa de preñez según la $\mathrm{CC}$ al

servicio 41

Pérdidas gestacionales y concentración de $\mathrm{P}_{4}$ 42

Dificultad en el diagnóstico de pérdidas embrionarias tempranas 
Concentraciones de $\mathrm{P}_{4}$ en ovejas preñadas vs. no preñadas .... 46

Concentraciones de $\mathrm{P}_{4}$ en relación con la $\mathrm{CC}$......................... 46

Hormonas metabólicas según el estado físiológico y la CC ... 47

CAPITULO III

PÉRDIDAS EMBRIONARIAS Y FETALES INFLUENCIADAS POR

CAMBIOS EN LA CONDICIÓN CORPORAL MATERNA

III.1 INTRODUCCIÓN

III.2 OBJETIVOS

III.3 HIPÓTESIS

III.4 MATERIALES Y MÉTODOS

III.4.1 Animales y lugar de trabajo 52

III.4.2 Tratamientos de alimentación 52

III.4.3 Sincronización de estros e inseminación artificial ......... 53

III.4.4 Muestreos 54

III.4.5 Tasa de fertilización y desarrollo embrionario................ 54

III.4.6 Análisis hormonales .................................................... 56

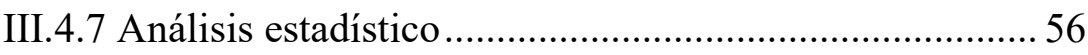

III.5 RESULTADOS

III.5.1 Tratamientos de alimentación y estado corporal materno 57

III. 5.2 Presentación de estros 58

III.5.3 Tasa de fertilidad y desarrollo embrionario .59

III.5.4 Diagnóstico de gestación y pérdidas gestacionales ......... 60

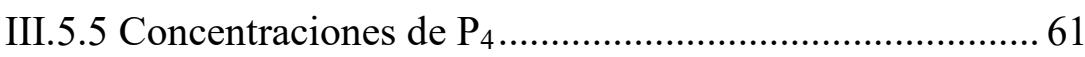

III.5.6 Metabolitos y hormonas metabólicas ............................. 62

III.6 DISCUSIÓN 65

Influencia de la $\mathrm{CC}$ en la presentación de estros..... 65

Cambios de CC, tasa de preñez y pérdidas gestacionales 66 
Relación entre el estado corporal, la tasa de fertilidad y el desarrollo embrionario temprano 70

Respuesta endocrino-metabólica al tratamiento nutricional ..... 71

CAPITULO IV .76

EFECTO DEL ESTADO NUTRICIONAL MATERNO SOBRE LA CALIDAD EMBRIONARIA Y EL AMBIENTE UTERINO DURANTE LA PREÑEZ

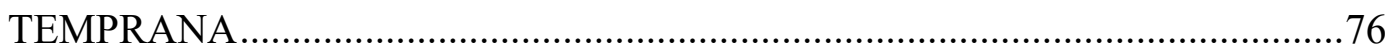

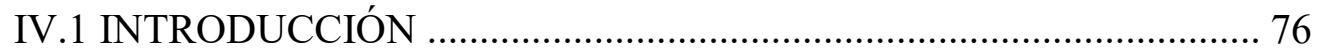

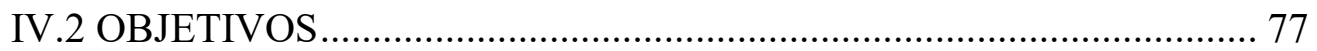

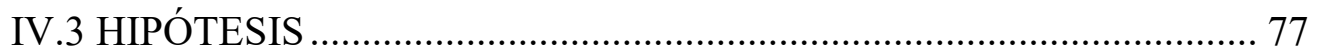

IV.4 MATERIALES Y MÉTODOS ……................................................. 78

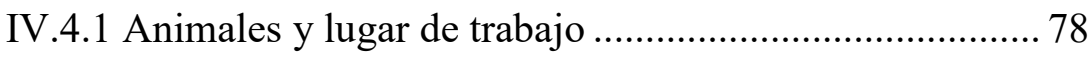

IV.4.2 Tratamientos nutricionales ........................................ 78

IV.4.3 Sincronización de estros y tratamiento de ovulación

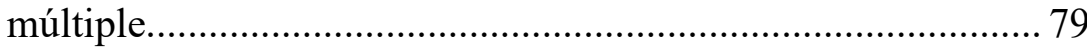

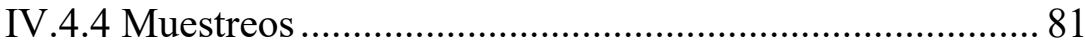

IV.4.5 Metabolitos y hormonas metabólicas............................ 81

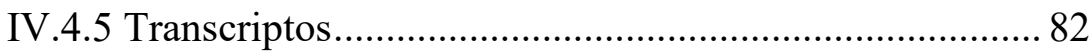

IV.4.6 Análisis estadístico...................................................... 83

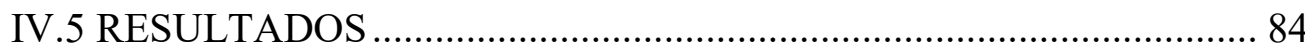

IV.5.1 Estado corporal de donantes y receptoras .................... 84

IV.5.2 Recuperación de embriones y calidad embrionaria ....... 84

IV.5.3 Tasa de preñez post siembra embrionaria ..................... 85

IV.5.4 Variaciones endocrino-metabólicas ............................. 86

IV.5.5 Evaluación de la expresión génica uterina.................... 89

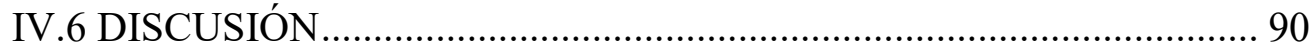

Respuesta al tratamiento MOET según el tratamiento nutricional 
Preñez y mortalidad embrionaria post siembra de embriones .. 91 Respuesta metabólica al tratamiento nutricional...................... 92 Expresión génica uterina en donantes y receptoras de embriones 95

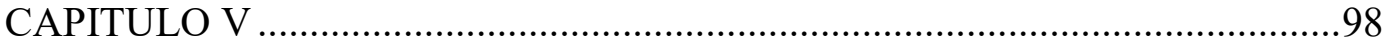

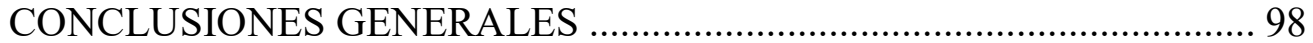

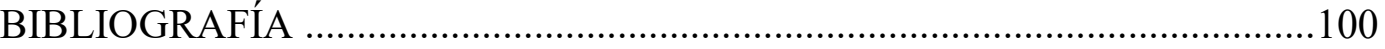

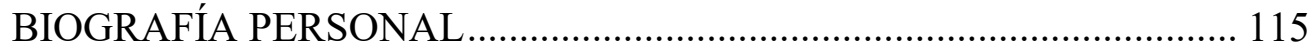




\section{LISTA DE ABREVIATURAS}

ACTB Control endógeno $\beta$-actina

AGNE Ácidos grasos no esterificados

$\beta$-OHB $\beta$-hidroxibutirato

CC Condición corporal

CE Colocación de esponjas intravaginales

CL Cuerpo lúteo

${ }^{\circ} \mathrm{C}$ Grados centígrados

DE Detección de celos

DG Diagnóstico de gestación

ES Error Estándar de la media

eCG Gonadotrofina coriónica equina

FSH Hormona folículo-estimulante

GH Hormona de crecimiento

GnRH Hormona liberadora de gonadotrofinas

h Horas

IAL Inseminación artificial laparoscópica

IGF-1 Factor de crecimiento insulínico tipo 1

IGF-2 Factor de crecimiento insulínico tipo 2

IGF-IR Receptor tipo I del IGF

INFAR Receptor de interferón alfa

INF $\tau$ Interferón tau

$\mathrm{kg}$ Kilogramos

$\mathrm{KgMS} / \mathrm{ha} \quad \mathrm{Kg}$ de materia seca por hectárea

LEPR Receptor de leptina

LH Hormona luteinizante

MAP Medroxiprogesterona

MMC Media por Mínimos Cuadrados

$\mu \mathrm{g}$ Microgramos

$\mu \mathrm{M} / \mathrm{L}$ Micro moles por litro (concentración micromolar)

$\mathrm{ml}$ Mililitros

$\mathrm{ng} / \mathrm{ml}$ Nanogramos por mililitros

Otp Proteína trofoblástica ovina

OTR Receptor de oxitocina

$\mathrm{P}_{4}$ Progesterona

PV Peso vivo

PR Receptor de progesterona

RE Retiro de esponjas intravaginales

REM Recuperación embrionaria

RIA Radioinmunoensayo

TE Transferencia embrionaria

UGO Unidad ganadera ovina 


\section{LISTA DE FIGURAS}

Capítulo

Página

I.1. Diagrama de las variaciones hormonales durante el ciclo estral en hembras ovinas.

II.1. Escala utilizada para la evaluación de la condición corporal en ovinos .....29

II.2. Cronograma de actividades para caracterizar las pérdidas de gestación en ovejas Merino

II.3. Distribución diaria de hembras ovinas que presentaron estros retornos entre los días 18 y 21 post retiro de esponja intravaginal con progestágenos

II.4. Concentración sérica de ácidos grasos no esterificados (AGNE; MMC $\pm E S$ ), en relación con la condición corporal (CC) (panel izquierdo) y el diagnóstico de gestación (DG) (panel derecho) en ovejas Merino en pastoreo entre los días -32 y 35 del servicio

II.5. Concentraciones séricas (MMC $\pm \mathrm{ES}$ ) de la hormona de crecimiento $(\mathrm{GH})$, de insulina, del factor de crecimiento similar a la insulina tipo 1 (IGF-1) y de leptina, en relación con la condición corporal (CC) (panel izquierdo) y el diagnóstico de gestación (DG) (panel derecho) en ovejas Merino en pastoreo entre los días -32 y 35 del servicio

III.1. Cronograma de actividades para evaluar la relación entre las pérdidas de gestación con los cambios en la condición corporal materna en ovejas Merino

III.2. Peso vivo y condición corporal desde 32 días pre-servicio hasta 35 días post servicio en hembras ovinas según el estado nutricional (Restringidas [R]; Suplementadas $[\mathrm{S}])$ 
III.3. Concentración sérica de ácidos grasos no esterificados (AGNE; MMC $\pm E S$ ), en relación al tratamiento nutricional (Restringido, [R], Suplementado [S]; panel izquierdo) y el diagnóstico de gestación (no preñadas; panel derecho) en ovejas Merino incluido los días -32 y 35 del servicio

III.4. Concentración sérica de la hormona de crecimiento (GH; MMC $\pm \mathrm{ES}$ ), en relación con el tratamiento nutricional (Restringido [R], Suplementado [S]; panel izquierdo) y el diagnóstico de gestación (no preñadas; panel derecho) en ovejas Merino entre los días 0 y 35 del servicio

III.5. Concentraciones séricas de insulina y factor de crecimiento similar a la insulina tipo 1 (IGF-1; MMC \pm ES), en relación con el tratamiento nutricional (Restringido [R]; Suplementado [S]; panel izquierdo) y el diagnóstico de gestación (no preñadas; preñadas; panel derecho) en ovejas Merino entre los días -32 y 35 del servicio.

IV.1. Protocolo utilizado para la producción, recuperación y transferencia de embriones en ovejas Merino

IV.2. Concentraciones séricas de ácidos grasos no esterificados (AGNE), de insulina, del factor de crecimiento similar a la insulina tipo 1 (IGF-1) y de leptina (MMC $\pm \mathrm{ES}$ ), en relación con el tratamiento nutricional (Restringido [R]; Suplementado [S]) de ovejas donantes de embriones (panel izquierdo, entre los días - 15 y 7 del estro) y de ovejas receptoras de embriones (panel derecho) en ovejas Merino (entre los días -15 y 35 del estro). .88

IV.3. Expresión relativa de transcriptos de ARNm del receptor de progesterona (PR) al día 7 post estro, en útero de ovejas donantes y receptoras según el tratamiento nutricional (Suplementadas $[\mathrm{S}]$ y Restringidas $[\mathrm{R}]$ ). .90 
IV.4. Expresión relativa de transcriptos de ARNm del receptor de IGF-1 (IGF-1R) y de leptina (LEPR) al día 7 post estro, en útero según el tratamiento nutricional (Suplementadas [S] y Restringidas [R]) .................................90 


\section{LISTA DE TABLAS}

\section{Capítulo}

\section{Página}

II.1. Peso vivo y condición corporal $(\mathrm{MMC} \pm \mathrm{ES})$ de ovejas al inicio del tratamiento progestacional (Día -32), al servicio (Día 0) y al día 35 post servicio.

II.2. Concentración sérica de $\mathrm{P}_{4}(\mathrm{MMC} \pm \mathrm{ES})$ entre los días 17 y 28 post servicio, en ovejas no preñadas (no cíclicas, cíclicas) y ovejas preñadas (sin y con pérdidas embrionarias) al día 35 post servicio

II.3. Concentración sérica de $\mathrm{P}_{4}(\mathrm{MMC} \pm \mathrm{ES})$ en los días 17, 21 y 28 post servicio en ovejas preñadas y no preñadas al día 17 (DG 17) y día 35 (DG 35) de gestación .38

II.4. Concentración sérica de $\mathrm{P}_{4}(\mathrm{MMC} \pm \mathrm{ES})$ del día 17 al 28 entre ovejas no preñadas y preñadas al día 35 post servicio según la $\mathrm{CC}$ al servicio (baja= $\leq 2,00$ y alta $=\geq 2,25)$

III.1. Peso vivo y condición corporal al servicio entre hembras que manifestaron estros y hembras que no manifestaron estros

III.2. Concentración sérica de $\mathrm{P}_{4}(\mathrm{MMC} \pm \mathrm{ES})$ en los días 17, 21 y 28 post servicio en ovejas no preñadas al día 17 post servicio y ovejas preñadas con y sin pérdidas embrionarias al día 35 (DG 35) de gestación

IV.1. Secuencia de oligonucleótidos usados para la amplificación de un fragmento de los genes de interés: receptor de progesterona (PR), del receptor de IGF-1 (IGF-1R) y del receptor de leptina (LEPR) y control endógeno $\beta$-actina (ACTB) 
IV.2. Eficiencia reproductiva de la recuperación embrionaria según el tratamiento nutricional (Suplementado $=\mathrm{S}$; Restringido $=\mathrm{R}$ ) en donantes de embriones..85

IV.3. Tasas de preñez al día 17 y 35 post estro y tasa de pérdidas embrionarias producidas entre el día 17 y 35 de gestación, según el tratamiento nutricional (Suplementadas [S]; Restringidas [R]) de las ovejas donantes y receptoras de embriones .86

IV.4. Concentraciones séricas de ácidos grasos no esterificados (AGNE), de insulina, del factor de crecimiento similar a la insulina tipo 1 (IGF-1) y de leptina en relación al diagnóstico de gestación (preñadas, no preñadas) al día 35 en ovejas Merino receptoras de embriones 


\title{
PÉRDIDAS REPRODUCTIVAS DE LA PREÑEZ SEGÚN EL ESTADO NUTRICIONAL MATERNO EN OVEJAS MERINO
}

\author{
Palabras claves: Pérdidas Embrionarias, Subnutrición, Ovinos
}

\section{RESUMEN}

En esta tesis se presentan los resultados derivados de la investigación de los efectos del estado nutricional sobre las pérdidas gestacionales y las modificaciones endócrino metabólicas en ovejas Merino. En el Experimento I se caracterizaron las pérdidas gestacionales producidas en ovejas Merino en condiciones de cría extensiva, evidenciando una baja proporción de pérdidas entre el día 17 post servicio y el parto $(3,27 \%)$. En el Experimento II se implementaron tratamientos nutricionales para evaluar el efecto de la condición corporal materna sobre el establecimiento y mantenimiento de la preñez. Principalmente se evidenció una disminución en la manifestación de los estros en ovejas restringidas $(65,1 \%)$ en comparación con ovejas suplementadas $(98,3 \%, \mathrm{P}<0,05)$, no hallándose diferencias en las tasas de preñez a los días 17 y 35 post servicio $(\mathrm{P}>0,05)$. Asimismo, los cambios negativos en la CC produjeron menor calidad embrionaria in vitro $\mathrm{y}$ alteraciones en las concentraciones de las principales hormonas metabólicas $(\mathrm{GH}$, Insulina e IGF-1). En el Experimento III, ovejas donantes y receptoras de embriones fueron asignadas a dos tratamientos de alimentación para estudiar si las fallas reproductivas se debían a factores del embrión, maternos o ambos. Se observó que la sobrevivencia embrionaria tendió a ser menor en las receptoras restringidas que recibieron embriones de donantes suplementadas ( $\mathrm{SR}, 27 \%)$ en comparación con 
los otros tratamientos $(64,64$ y $57 \%$ para SS, RS y RR, respectivamente, $\mathrm{P}<0,1)$. El estado nutricional materno afectó las concentraciones de AGNE, insulina, IGF1 y leptina y la expresión génica uterina del PR, IGF-1R y LEPR. Se concluye que la subnutrición materna modificó la calidad embrionaria, el ambiente endócrino metabólico y la expresión génica uterina, hallándose una tendencia a una mayor mortalidad embrionaria tardía en ovejas subnutridas respecto a ovejas suplementadas $(\mathrm{P}<0.1)$. Además, la subnutrición preservicio indujo el anestro en el $35 \%$ de los animales. 


\section{PREGNANCY REPRODUCTIVE LOSSES ACCORDING}

\section{TO THE MATERNAL NUTRITIONAL STATUS IN MERINO}

\section{SHEEP}

Key words: Embryo Losses, Undernutrition, Sheep

\section{SUMMARY}

This dissertation presents the results derived from the investigation of the effects of nutritional status on pregnancy losses and metabolic endocrine modifications in Merino sheep. In Experiment I, pregnancy losses were characterized in Merino sheep under extensive breeding conditions, showing a low proportion of losses between day 17 post-mating and parturition (3.27\%). In Experiment II, nutritional treatments were implemented to assess the effect of maternal body condition on the establishment and maintenance of pregnancy. Mainly, there was a decrease in the manifestation of estrus in the restricted feed intake group (65.1\%) compared with supplemented $(98.3 \%, \mathrm{P}<0.05)$, with no differences in pregnancy rates on days 17 and 35 post-mating $(\mathrm{P}>0.05)$. Likewise, negative changes in body condition produced lower in vitro embryo quality and alterations in the concentrations of the main metabolic hormones $(\mathrm{GH}$, Insulin and IGF-1). In Experiment III, donor and recipient embryo sheep were assigned to two nutritional treatments to study whether reproductive failures were due to embryo factors, maternal or both. It was observed that embryo survival tended to be lower in restricted recipients who received embryos from supplemented donors (SR, 27\%) compared with the other treatments $(64,64$ and $57 \%$ for SS, RS and RR, respectively, $\mathrm{P}<0.1)$. Maternal nutritional status affected the concentrations of 
NEFA, insulin, IGF-1 and leptin and the uterine gene expression of PR, IGF-1R and LEPR. I concluded that maternal undernutrition modifies embryo quality, metabolic endocrine environment and uterine gene expression; a tendency to higher late embryonic mortality was found in nutritional restricted sheep compared to supplemented sheep $(\mathrm{P}<0.1)$. In addition, pre-mating undernutrition induced anestrus in $35 \%$ of the restricted animals. 


\section{CAPITULO I}

\section{I.1 INTRODUCCIÓN}

\section{Breve descripción del sistema productivo ovino en la Patagonia Norte}

Los sistemas de producción ganadera en el norte de la región Patagónica se desarrollan principalmente en condiciones de pastoreo extensivo sobre pastizales naturales. Esta región se divide en áreas eco-productivas homogéneas que presentan características similares de geología, relieve, suelo, vegetación, clima y sistemas de producción (Siffredi y col., 2011). Entre ellas se encuentra el área ecológica de Sierras y Mesetas Occidentales (Soriano, 1954), que ocupa una superficie de 3.538.500 hectáreas, en la provincia de Río Negro. El clima es predominantemente árido y frío, con un promedio de 150 a $300 \mathrm{~mm}$ anuales concentrados en otoño e invierno, y la temperatura anual media es de 8 a $10^{\circ} \mathrm{C}$. Predomina la estepa de arbustos bajos y coirones, presentando también mallines dulces y salados (Bran y col., 2000) variando la producción anual de forraje según el sitio y la condición del pastizal (500 a $8000 \mathrm{Kg} \mathrm{MS/ha)} \mathrm{(Bonvissuto} \mathrm{y} \mathrm{col.,} \mathrm{2008).} \mathrm{En} \mathrm{esta} \mathrm{zona,} \mathrm{la}$ producción ovina es el sustento principal de los productores, predominando una gran cantidad de pequeños productores y unas pocas empresas más grandes. Prácticamente el 100\% de los ovinos son de raza Merino, orientados a la producción de lana fina y carne como subproducto (Mueller, 2005). La tasa de prolificidad de esta raza es baja, lo cual ocasiona la necesidad de asegurar todas las etapas del proceso productivo desde el servicio hasta el destete, para poder obtener un buen porcentaje de señalada. La señalada expresa el porcentaje anual de corderos 
obtenidos (señalados) en relación al total de madres al momento del servicio (Easdale, 2010), y en estos sistemas de producción laneros no se supera el 55\% (Claps, 2010). Debido a la escasez de forraje en algunos momentos del año y a procesos de desertificación (Del Valle y col., 1997), la actividad tiene pocas posibilidades de crecer a través del aumento en el stock; por lo que las mejoras en la producción deben basarse en aumentos en la productividad por animal, logrando una mayor calidad de lana y una mayor tasa reproductiva. Para esto último, es indispensable asegurar una buena nutrición materna previo al servicio y durante la gestación, lo que podría alcanzarse a través de un buen manejo del forraje disponible, evitando períodos de subnutrición que perjudiquen el rendimiento productivo de los animales (Villar, 2011).

\section{Fisiología y endocrinología del ciclo estral ovino}

La oveja puede ser definida como una hembra poliéstrica estacional (Fernández Abella, 1993) cuya actividad reproductiva depende del fotoperíodo, teniendo lugar durante el período en que las horas luz decrecen, que se corresponde con el otoño. Experiencias realizadas en la raza Merino, por el grupo de Reproducción en Rumiantes Menores del Instituto Nacional de Tecnología Agropecuaria (INTA) Bariloche, demostraron que entre el 95 y 100\% de las ovejas se encuentra ciclando entre los meses de marzo y julio; estos porcentajes disminuyen a valores de alrededor del 60\% entre agosto y febrero (Wolff y col., 1992; Cueto y col., 1993). 
Cuando la hembra alcanza la pubertad manifiesta cambios rítmicos en su conducta sexual (aceptación de la cópula), denominándose a esta actitud como celo o estro. Los acontecimientos que comienzan en un estro y finalizan en el siguiente reciben el nombre de ciclo estral, el cual tiene una duración de $17 \pm 1$ días en la oveja (Baril y col., 1995). El ciclo estral puede dividirse en dos fases. La fase folicular comprende un período temprano caracterizado por el crecimiento y maduración folicular preovulatoria, y un período tardío que comienza con la manifestación del celo y termina con la ovulación (Scaramuzzi y col., 1993). La fase luteal es más larga, y comienza post ovulación con la formación del cuerpo lúteo hemorrágico, el cual posteriormente se constituirá en un CL, y finalizará con su luteólisis. En la oveja, la vida media del CL es de aproximadamente 12-14 días (Baril y col., 1995). El ciclo estral está regulado por una interacción hormonal, controlada por el eje hipotálamo-hipófisis-ovario, que incluye procesos de retroalimentación positiva y retroalimentación negativa. Los perfiles hormonales durante la fase folicular y la fase luteal se muestran en la figura I.1.

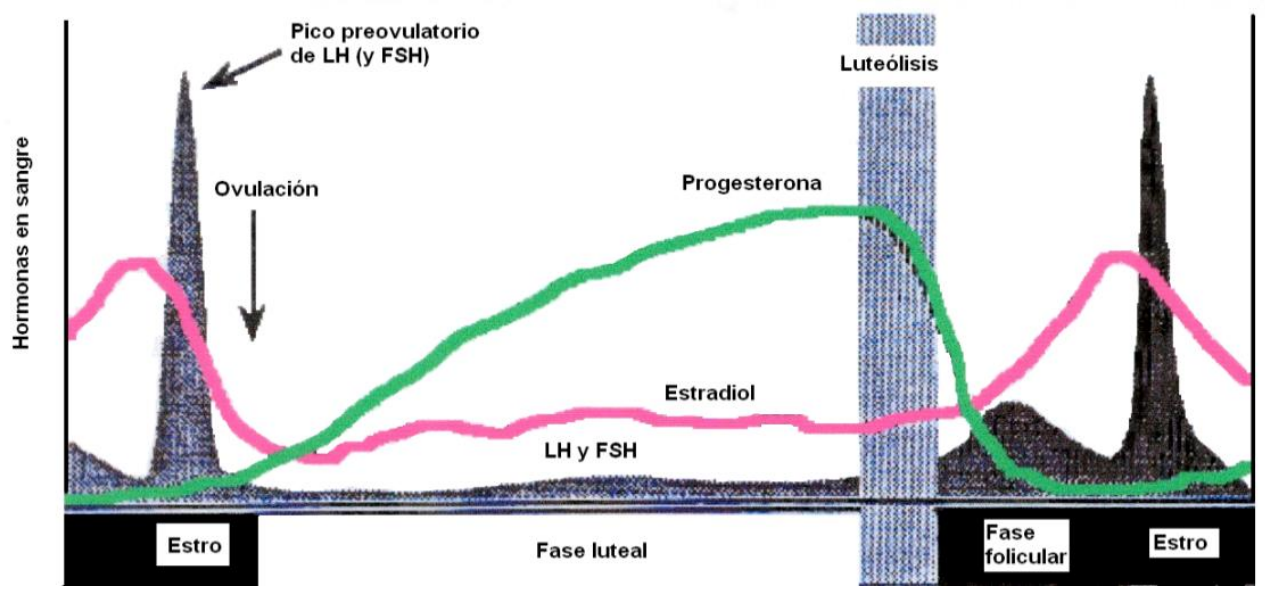

Figura I.1. Diagrama de las variaciones hormonales durante el ciclo estral en hembras ovinas (Martin y Thomas, 1990). 


\section{Gestación}

La gestación en la oveja tiene una duración promedio de 148 días (Hafez, 1996) y puede ser dividida en dos grandes etapas de desarrollo, la embrionaria (Día 0 al 35) y la fetal (Día 36 al parto) (Fernández Abella, 1993). Al igual que en otros mamíferos, los eventos que transcurren durante los primeros días siguientes a la ovulación son determinantes para la supervivencia del embrión (Watson y col., 1999). Luego de producida la fecundación, tiene lugar un mecanismo de señalización entre el embrión, el endometrio y el ovario, a fin de evitar la regresión del CL, asegurándose de esta manera la producción y secreción de $\mathrm{P}_{4}$, lo que favorece el desarrollo temprano del embrión, la implantación, la placentación y un correcto desarrollo feto-placentario hasta el término de la gestación (Graham y Clarke, 1997).

\section{Desarrollo embrionario temprano}

Una vez que el ovocito ovulado es fecundado, se forma el embrión quien sufre sus primeras divisiones celulares en el oviducto y alcanza el útero alrededor del día 4 post-celo, en el estadio embrionario de mórula compacta. Hacia el día 6 se forma el blastocisto joven, las células se compactan y por ingreso del líquido extracelular se forma una cavidad rodeada por células trofoblásticas. El blastocisto, en su forma esférica, se expande y eclosiona de la zona pelúcida entre los días 8 y 9. Hacia el día 11 va adoptando una forma tubular y luego se elonga convirtiéndose en un embrión filamentoso entre los días 12 y 16 . La elongación del blastocisto coincide con el comienzo de la implantación, aunque la adhesión firme al endometrio no ocurre hasta el día 16 (Wintenberger-Torres y Flechon, 1974). El 
período de desarrollo de los embriones previo a la implantación puede ser dividido en dos fases, temprana y tardía, correspondiendo al tiempo en que están alojados en oviducto y útero, respectivamente (Leese, 1995). La importancia de esta etapa en la supervivencia embrionaria se pone de manifiesto en la alta incidencia de mortalidad embrionaria que ocurre en este momento de la gestación (Goff, 2002). Durante las últimas décadas se han acumulado numerosas evidencias sobre la participación en esta etapa de muchas hormonas y factores de crecimiento que determinan la viabilidad futura del embrión (Kaye, 1997; Abecia y col., 1999; 2006; Sosa y col., 2009a; Abecia y col., 2015).

\section{Reconocimiento materno de la gestación}

El proceso por el cual el embrión señala su presencia al sistema materno y prolonga la vida del $\mathrm{CL}$, ha sido denominado reconocimiento materno de la gestación (Short, 1969). En la década del 60, Moor y col. (1969) establecieron que el momento crítico para mantener la vida del CL en la oveja estaba entre los días 12 y 13 de gestación y que existía alguna sustancia que el embrión secretaba para evitar la luteólisis. Más tarde, Godkin y col. (1982) purificaron la proteína responsable de bloquear el mecanismo luteolítico, la proteína trofoblástica ovina (oTP). Esta proteína tiene propiedades antivirales, anti proliferativas e inmunosupresoras y presenta una gran homología con la secuencia del interferón $\alpha$, por lo que se la clasificó dentro de la familia de los interferones tipo I (Imakawa y

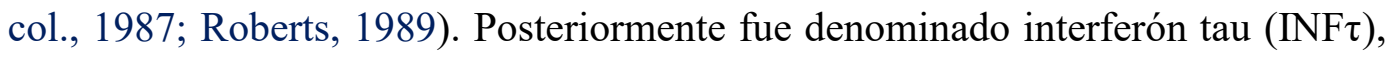
por ser el interferón trofoblástico (Roberts y col., 1992). 
El INF $\tau$ es sintetizado por el trofectodermo entre los días 10 y 21 de gestación (Spencer y col., 1998), presentando máximas concentraciones al día 14 de gestación (Godkin y col., 1982; Hansen y col., 1988; Spencer y col., 2004). Algunos autores han observado concentraciones apreciables de la proteína en el medio de cultivo de los embriones de día 8 (Ashworth y Bazer, 1989). La secreción de INF $\tau$ ovino (ng/lavaje uterino) aumenta rápidamente según el conceptus cambia morfológicamente de forma esférica (312 ng) a tubular (1.380ng) a filamentosa (4.455 ng) en los días 12 a 13 (Rutter y Russo, 2002). El INF $\tau$ actúa a través del receptor de interferón $\alpha$ (INFAR) en forma paracrina sobre los epitelios luminal y glandular endometriales para evitar la transcripción del gen del receptor de oxitocina (OTR), inhibiendo primero la síntesis del receptor de estrógenos (ER $\alpha)$, suprimiendo de esta manera el desarrollo del mecanismo luteolítico en el endometrio (Spencer y Bazer, 1996; Bathgate y col., 1998). La mayor producción de INF $\tau$ está asociada a la elongación del embrión, pero el aumento se debe principalmente al aumento de tamaño del trofoblasto más que a un incremento en su tasa de síntesis (Goff, 2002). La elongación rápida del trofoblasto es imprescindible para una mayor síntesis de INF $\tau$, ya que su ARNm sólo se encuentra en sus células trofoblásticas extraembrionarias y es casi inexistente en otras partes del embrión (Farin y col., 1989; Guillomot y col., 1990; Gray y col., 2002). Es decir que el tamaño es importante para evitar la luteólisis ya que embriones pequeños no producirán suficiente INF $\tau$. Algunos autores han observado un retraso en el desarrollo embrionario al día 8 de gestación (Abecia y col., 1997) y una menor producción de INF $\tau$ al día 15 de gestación (Abecia y col., 1999) en ovejas subnutridas, viéndose perjudicada la supervivencia embrionaria de los mismos. 


\section{Pérdidas prenatales}

El mantenimiento del o los embriones durante la preñez hasta la expulsión del feto en el parto requiere de una serie de interacciones adecuadas entre el sistema materno y el desarrollo de los conceptos. Tanto el endometrio como el embrión sintetizan y secretan a la interfase entre el embrión y la madre una miríada de factores de crecimiento, proteínas, citoquinas, hormonas y otras sustancias que interactúan entre ambas partes (Martal y col., 1997). Las pérdidas prenatales se diferencian en mortalidad embrionaria y fetal. La mortalidad embrionaria se define como la pérdida del embrión entre la concepción y el fin del período embrionario de diferenciación (día 35). En este caso se produce la reabsorción total del embrión sin observación de ningún síntoma, salvo una extensión anormal del intervalo entre celos. Contrariamente, las pérdidas fetales o abortos se manifiestan por la expulsión prematura del feto no viable a partir del día 35 de gestación (Fernández Abella, 1993).

La mortalidad embrionaria es una de las mayores causas de fallas reproductivas en todos los animales domésticos (Diskin y Morris, 2008; Walsh y col., 2011). Se ha observado que entre un 25 y un $55 \%$ de todos los embriones mamíferos se pierden durante la gestación temprana (Niswender y Nett, 1994). En vacas, la mayor mortalidad embrionaria ocurre durante las primeras tres semanas de gestación (Inskeep y Dailey, 2005; Diskin y Morris, 2008), habiendo discrepancias en si es mayor en la primera semana post concepción (Sartori y col., 2002) o en la segunda (Diskin y Screenen, 1980). Algunos autores indican que, en el ovino, esto ocurriría alrededor de la segunda semana, en el momento de 
implantación (día 9 al 15, Hafez, 1996). En el ganado bovino, Walsh y col. (2011) consideran dividir la mortalidad embrionaria en tres períodos; si esto se extrapola al ganado ovino podríamos sugerir que existe una mortalidad embrionaria muy temprana entre los días 0 y 7 (formación del blastocisto); una mortalidad embrionaria temprana desde el día 7 al 16 (período de implantación) y una mortalidad embrionaria tardía entre los días 16 al 35 (fin del período embrionario). Del día 35 hasta el parto la pérdida prenatal es considerada como mortalidad fetal.

\section{Evaluación del estado nutricional}

La valoración del estado nutricional de los animales se ha basado en la medida del peso vivo (PV) y la determinación de los perfiles metabólicos. Sin embargo, hace ya muchos años que se ha venido utilizando la condición corporal (CC) como un indicador subjetivo de fácil aplicación para establecer las relaciones entre alimentación y producción (Molina y Gallego, 1993). La CC ha logrado extensa aceptación en la producción ovina, especialmente como un indicador del estado nutricional de las ovejas, siendo indudablemente un muy buen indicador práctico para la evaluación y el control de las reservas corporales (Bocquier y col., 1988; Croston y Pollot, 1994).

La CC se determina evaluando manualmente el grado de cobertura grasa del proceso espinal y las apófisis transversas de las vértebras lumbares, en base a una escala de cinco puntos (1-5, Russel y col., 1969). Sin embargo, su utilización tal cual ha sido originalmente diseñada, no suministra información de mucha utilidad, ya que, en el norte de la región patagónica, el rango que se obtiene es estrecho, entre 
1 y 3 puntos de $\mathrm{CC}$, con la detección excepcional de uno que otro animal de 4 puntos, generalmente vinculado a animales de cabañas. Debido a ello surge la inquietud y necesidad de dividir la escala e incorporar el medio $(0,5)$ y el cuarto punto $(0,25)$ (Buratovich, 2000).

Los efectos de la nutrición sobre las variables reproductivas pueden ser “agudos" cuando no están reflejados por cambios en el PV; “estáticos" cuando reflejan diferencias mantenidas en el PV o la CC debido a la historia nutricional o fisiológica de las semanas/meses previos, o "dinámicos" cuando obedecen a cambios de PV o CC en períodos más cortos (días/semanas, Chilliard y col., 1998; Scaramuzzi y col., 2006). La CC tiene el beneficio de que no es afectada por los cambios de tamaño y peso del feto, como sucede con el peso vivo de la oveja, el que se incrementa según avanza la gestación (Russel, 1985; Vera y Vega, 1986). Uno de los usos principales de la CC en el manejo de majadas, es su empleo en los momentos clave del ciclo reproductivo. La experiencia indica que en las majadas de la raza Merino del norte de la Patagonia la condición al momento del servicio, para obtener una buena preñez, debiera ser mayor a 2,5 (Giraudo, 2009). Por otra parte, existe mucha variación para las mismas majadas, producto del clima y del manejo (Giraudo y Villagra, 2008), que determinan que los resultados en muchas situaciones se aparten de ese óptimo, con las consecuencias correspondientes, tanto en la preñez como en el parto.

Como se ha citado anteriormente el estado nutricional también puede evaluarse a través del perfil metabólico del animal utilizando indicadores bioquímicos. El rango de movilización de las reservas grasas depende de la cantidad 
de tejido adiposo de que disponga la oveja y la diferencia entre el consumo y la demanda de nutrientes (particularmente de energía). Un bajo suministro de glucosa por subnutrición llevará a la movilización de ácidos grasos libres que reducen el apetito y potencian la formación de cuerpos cetónicos (Faulkner, 1983). Son numerosos los autores que han utilizado los ácidos grasos no esterificados (AGNE) y los cuerpos cetónicos, especialmente el $\beta$-hidroxibutirato $(\beta-\mathrm{OHB})$, como indicadores del metabolismo energético en los animales. El $\beta$-OHB ha demostrado ser un buen indicador de la subnutrición en ovinos en condiciones extensivas (Russel y col., 1967), pudiendo utilizarse como un estimador para establecer si las ovejas cubren sus requerimientos con el consumo de nutrientes. Estos autores determinaron que valores de $1,1 \mathrm{mM}$ y $1,6 \mathrm{mM}$ de $\beta$-OHB en sangre indican grados de moderada y severa subnutrición, respectivamente, siendo $0,71 \mathrm{mM}$ el valor normal de nutrición en ovinos. Si bien son menos sensibles que otros metabolitos, como los AGNE, su manipulación y conservación es muy simple y no presentan los problemas de sesgo de los AGNE, que aumentan en sangre como respuesta al estrés (Oregui, 1992). Sin embargo, en un estudio más reciente, se demostró que, en ovejas, la concentración de AGNE puede ser utilizado como un indicador fiable del estado energético de los animales, no encontrando modificaciones en la concentración de $\beta$-OHB frente a distintos niveles de alimentación $(30,60,100$ y $120 \%$ de requerimientos de mantenimiento) en ovejas con diferente estado corporal $(1,25-2,0-3,0$ y 4,0), respectivamente (Caldeira y col., 2007a). Las concentraciones de AGNE pueden ser utilizadas como indicador de los grados moderados de subnutrición (principio y mitad de gestación); su determinación expresa el equilibrio entre lipólisis y lipogénesis, pero es menos útil en situaciones de 
prolongada y severa subnutrición (Russel y col., 1967). Caldeira y col. (2007a; 2007b) evidenciaron mayores concentraciones de AGNE en ovejas con baja condición corporal (1,25 y 2,00). Asimismo, Sosa y col. (2009a) y otros autores observaron diferencias significativas en las concentraciones de AGNE entre ovejas subnutridas y controles (Erfle y col., 1974; Russel, 1979; Robinson, 1980; Topps y Thompson, 1984).

\section{Efecto de la nutrición sobre el eje reproductivo}

La relación existente entre la nutrición y sus efectos sobre la función reproductiva en los rumiantes ha demostrado ser muy compleja, siendo objeto de numerosos estudios (Chilliard y col., 1998; O’Callaghan y Boland, 1999; Martin y col., 2004a; Abecia y col., 2006; Scaramuzzi y col., 2006). Aunque uno de los aspectos más estudiados de esa relación ha sido el efecto de la sobrealimentación o suplementación (flushing) como herramienta para incrementar la tasa de ovulación (Rhind, 1992; Banchero y Quintans., 2004), también existen algunos estudios sobre el efecto de la subnutrición y sobrealimentación en el eje hipotálamo-hipófisogonadal en los rumiantes (Robinson, 1996; Boland y col., 2001; Forcada y Abecia, 2006). Al respecto, se ha observado que ovejas subnutridas, a largo y a corto plazo, presentaron una disminución de las concentraciones basales de FSH y LH, así como también una disminución en la frecuencia de pulsos de LH (Thomas y col., 1990; O'Callaghan y col., 2000). Algunos trabajos han observado una menor tasa de ovulación en ovejas subnutridas (McNeilly y col., 1987; Rhind y col., 1989a) mientras que en otros no se evidenciaron estas diferencias (Lozano y col., 2003; Kakar y col., 2005). Se ha descrito que la calidad de los ovocitos (en cuanto a su 
morfología) de ovejas subnutridas es inferior a la de las controles (Lozano y col., 2003). Esta menor calidad de los ovocitos recolectados también ha sido manifestada en ovejas con sobrealimentación (McEvoy y col., 1995).

Comparados con la cantidad de estudios que investigan los efectos de la nutrición sobre el eje hipotálamo hipófisis ovario, los estudios que investigan sus efectos sobre el desarrollo embrionario y el ambiente uterino son escasos.

Efecto del estado nutricional materno sobre el desarrollo embrionario y fetal

Inicialmente, los estudios del impacto de la nutrición en el crecimiento del feto se concentraron en el tercio final de la gestación, prestando poca atención a los niveles nutricionales en el período pre-servicio y durante los estadios iniciales de la preñez. Sin embargo, actualmente se ha evidenciado que los efectos de la nutrición se ejercen muy temprano en el desarrollo embrionario. Al inicio de la gestación, el desarrollo embrionario y el crecimiento del feto es muy lento y sus necesidades nutritivas son extremadamente bajas. Pese a esto, se ha visto que los niveles de alimentación extremos, tanto de subnutrición como de sobrealimentación, pueden reducir la supervivencia embrionaria o retrasar el crecimiento del feto, debido a una alteración del equilibrio hormonal progesterona/estrógenos que modifica la composición del fluido uterino (Jimeno y col., 2002).

Muchos estudios han demostrado que en los pequeños rumiantes las concentraciones plasmáticas de $\mathrm{P}_{4}$ están inversamente relacionadas con el nivel 
nutricional durante la preñez (Williams y Cumming, 1982; Parr y col., 1987; Rhind y col., 1989b), observándose una reducción en la concentración de $\mathrm{P}_{4}$ plasmática cuando aumenta el consumo (Parr y col., 1982) y cuando la dieta alcanza niveles de dos veces los requerimientos energéticos para mantenimiento (O'Callaghan y col., 2000). Parr (1992) propuso que este efecto podría deberse a una mayor metabolización hepática de la $\mathrm{P}_{4}$ en ovejas sobrealimentadas, dada por el aumento del flujo sanguíneo en la vena porta. Al mismo tiempo, los esteroides se almacenan selectivamente en el tejido adiposo, por lo que se ha sugerido que un régimen de alimentación que resulte en lipólisis llevará aparejado una liberación de estos (Boland y col., 2001). En ovejas subnutridas, el aumento de la concentración de $\mathrm{P}_{4}$ plasmática ha sido asociado con mayores porcentajes de pérdidas embrionarias (Brien y col., 1981). Frente a esta situación Rhind y col. (1989c) sugirieron que quizá la medición de $\mathrm{P}_{4}$ circulante no fuera suficiente reflejo de la situación en el tracto reproductivo, debiendo medirse las concentraciones a nivel local. En este sentido, no se han observado diferencias en las concentraciones de $\mathrm{P}_{4}$ en la vena ovárica ni en la arteria uterina entre ovejas subnutridas y controles (Abecia y col., 1997; Lozano y col., 1998a), pero este último estudio sí demostró una menor concentración de $\mathrm{P}_{4}$ en el tejido endometrial de ovejas subnutridas el día 5 del ciclo estral respecto a los controles, lo que podría explicar el desarrollo embrionario inadecuado que presentaron las primeras.

En sistemas extensivos, el esquema nutricional al que están sometidos los animales presenta grandes fluctuaciones a lo largo del año (Lindsay y col., 1993), siendo la subnutrición un problema en los rebaños comerciales donde la 
alimentación está basada en el pastoreo. En ovinos algunos autores han reportado un incremento de la mortalidad embrionaria en diferentes días $(11,15,21)$ de gestación en ovejas subnutridas sometidas a dietas restringidas o por un consumo disminuido (Rhind y col., 1989c; Abecia y col., 1999; Rhind y col., 1985). Sin embargo, en trabajos con tratamientos nutricionales similares, se ha recuperado un porcentaje similar de embriones en ovejas subnutridas y controles los días 4, 8 y 9 , aunque los embriones de las hembras subnutridas presentaban retraso en su desarrollo (Lozano y col., 2003; Abecia y col., 1997; Abecia y col., 1999). Asimismo, Abecia y col. $(1995,1997,1999)$ no encontraron diferencias en las tasas de gestación debidas a la subnutrición en los días 8 y 9, pero sí en los días 14 y 15 de gestación.

La menor tasa de gestación en ovejas subnutridas podría obedecer a una alteración en las señales bioquímicas que se establecen entre el embrión y el ambiente uterino (Lozano y col., 1998b), considerando que a edad muy temprana se establece un "diálogo bioquímico" sincronizado entre el embrión y su madre, que determinará el éxito o el fracaso de la gestación (Abecia y col., 2006). La mortalidad embrionaria temprana es una causa importante del fracaso reproductivo y podría estar relacionada con las influencias nutricionales durante la época de apareamiento (Dunne y col., 1999).

Se ha visto que, en estación reproductiva, un descenso de la CC de 2,00 a 1,50 implica una reducción en la tasa de preñez del orden del 5\% (Gibbons, 1993). También Fernández Abella y Formoso (2007) observaron un alto porcentaje de pérdidas embrionarias $(22,7 \%)$ en ovejas con una CC menor a 2,25. 
Algunos estudios han reflejado que estados nutricionales deficientes al inicio de la gestación provocan lesiones y enfermedades que se expresarán más tarde en la vida postnatal (Bispham y col., 2003; Fowden y Forhead, 2004; Lea y col., 2006; MacLaughlin y col., 2010; Kiani y col., 2011). Se ha observado que si la hembra recibe una alimentación restringida durante el momento de la formación de la placenta, se generará un menor número de cotiledones, los cuales presentarán un menor tamaño y que esta condición se traducirá en un bajo desarrollo fetal, influyendo negativamente en el peso al nacimiento y en la sobrevida del cordero (Dingwall y col., 1987).

El estado nutricional se interrelaciona con el sistema reproductivo por vía de un complejo sistema de señales bioquímicas, que involucran tanto a nutrientes como a hormonas, además de a sus respectivos receptores.

\section{Mediadores entre el estado metabólico y el desarrollo embrionario-fetal}

Es muy probable que los efectos de los cambios en el estado metabólico sobre la gestación temprana se ejerzan por medio de una señalización diferencial de las hormonas metabólicas, más que por una falta de nutrientes per se. Varias de las hormonas metabólicas que ayudan a mantener la homeostasis del organismo, y cuyas concentraciones plasmáticas varían con los cambios en el estado metabólico, han sido postuladas como posibles mediadores entre éste y el sistema reproductivo de un animal. Entre los candidatos más probables de mediar entre los cambios 
nutricionales y el ambiente uterino se encuentran la insulina, el IGF-1 y la leptina (Blache y col., 2006).

La insulina corresponde a un polipéptido de alto peso molecular de $6 \mathrm{kDa}$ que es secretado por las células beta del páncreas como parte de una pre-prohormona (Tang y col., 1997), que cuando se pliega, en el retículo endoplásmico, forma la proinsulina. Posteriormente, ésta se transporta en micro vesículas desde el retículo endoplásmico al complejo de Golgi, en el cual se empaca en conjunto a enzimas proteolíticas que, al activarse, convierten la proinsulina en insulina, como resultado del desprendimiento del péptido C. Normalmente un 90 a $97 \%$ del producto liberado, por parte de las células beta corresponde a insulina junto con cantidades equimolares del péptido C. La mayor parte del resto corresponde a proinsulina (Brook y Marshall, 1996).

Esta insulina evoca respuestas biológicas en tres lugares distintos de la célula: en la membrana plasmática estimula el transporte de glucosa, aminoácidos e iones; en el citoplasma activa enzimas como glucógeno sintetasa y piruvato deshidrogenasa, activando procesos de fosforilación y desfosforilación; y en el núcleo regula la síntesis de ARN y ADN (Ward, 1988). Su principal función es mantener la homeostasis de la glucosa, que depende del balance entre la producción de glucosa y su utilización por los tejidos insulinodependientes. Los tejidos efectores más importantes son el hepático, el muscular y el adiposo, pero además esta hormona ejerce efectos reguladores potentes sobre otros tipos celulares (Cheatham y Khan, 1995), como, por ejemplo, en el hipotálamo (Tang y col., 1997). 
La insulina es la principal hormona responsable de controlar el almacenamiento y la utilización de los nutrientes celulares. Activa los sistemas de transporte y las enzimas que intervienen en la utilización y depósito intracelular de glucosa, aminoácidos y ácidos grasos, a la vez que inhibe procesos catabólicos como la degradación de glucógeno, lípidos y proteínas (Cheatham y Khan, 1995). Estudios recientes demostraron que la insulina fue uno de los indicadores metabólicos más eficientes en reflejar el estado nutricional de las ovejas, obteniendo concentraciones significativamente inferiores en ovejas con 1,25 y 2,0 de CC con respecto a animales con 3,0 y 4,0 de CC (Caldeira y col., 2007a; 2007b) En ovejas sometidas a flushing nutricional se evidenció un aumento del nivel de insulina (Scaramuzzi y col., 2006) y en ovejas subnutridas se observaron menores concentraciones de insulina que en los animales controles (Sosa y col., 2006).

El incremento de la entrada de glucosa a las células ha sido relacionado positivamente con los aumentos en la tasa ovulatoria en ovejas (Downing y col., 1995). Investigaciones realizadas en bovinos, concluyen que la insulina en concentraciones fisiológicas influye directamente en la proliferación de las células tecales in vitro, actuando sinérgicamente con la $\mathrm{LH}$, estimulando la esteroideogénesis. En períodos de restricción alimenticia, cuando los niveles de LH e insulina son bajos, la diferenciación de las células tecales está disminuida. Por consiguiente, estos resultados postulan a la insulina como un importante estimulador de la mitogénesis y esteroideogénesis durante el desarrollo folicular del ovario de rumiantes (Stewart y col., 1995).

Aunque en nuestro conocimiento no hay información disponible acerca de los posibles efectos directos de la insulina en la fisiología uterina, los IGFs, péptidos 
relacionados con la insulina, sí han sido implicados en el estado del ambiente uterino.

Los factores de crecimiento insulínicos tipo 1 y 2 (IGF-1 e IGF-2) son polipéptidos sintetizados principalmente en el hígado y liberados a la circulación general como respuesta a la estimulación por GH (Le Roith y col., 2001). También órganos de importancia reproductiva como el hipotálamo, hipófisis, ovario, oviducto, el útero y especialmente la placenta; son capaces de sintetizarlos, lo mismo que otros órganos como el corazón, el pulmón, el riñón, el páncreas, el bazo, los intestinos delgado y grueso, el cerebro y la médula espinal (Butler y Le Roith, 2001). Los principales tejidos diana afectados en combinación con la hormona del crecimiento son los músculos, cartílagos, huesos, hígado, riñones, nervios, piel, ovarios y pulmones (Daftary y Gore, 2005). El IGF-1 cumple un papel importante en la reproducción de los rumiantes, tanto directamente cumpliendo funciones sobre el sistema reproductivo como indirectamente siendo indicador de una aceptable condición corporal y aptitud reproductiva (Velázquez y col., 2008). El IGF-1 que se origina en las células de la teca del ovario, participa en el crecimiento, desarrollo y maduración folicular y juega un papel importante en la foliculogénesis inducida por las gonadotrofinas, en la esteroideogénesis ovárica y en la función del cuerpo lúteo (CL) (Lenz Souza y col., 2007). En el útero, ambos IGFs estimulan el desarrollo de los embriones pre-implantación, actúan en el desarrollo fetal y controlan el desarrollo placentario (Wathes, 1998). El IGF-1 podría influenciar la supervivencia de embriones directamente después de su traslado al lumen del tracto reproductivo, o indirectamente a través de acciones en el ovario, oviducto o útero 
(Peña y col., 2007; Velázquez y col., 2008). En embriones, se ha demostrado claramente que el IGF-1 puede ejercer un efecto positivo en la preimplantación de la especie bovina y en el desarrollo del embrión (Lima y col., 2006; Stefanello y col., 2006). Los efectos sobre el embrión están mediados por la acción directa de IGF-1, ya que se ha observado la presencia de receptores de IGF-1 en el embrión durante el desarrollo (Coppola y col., 2009; Velázquez y col., 2011). Sin embargo, sigue siendo incierto si el IGF-1 circulante en realidad llega al embrión, ya que no hay ninguna correlación entre las concentraciones de IGF-1 en plasma y en el líquido luminal uterino (Bilby y col., 2006). Por otro lado, la alta expresión de receptores de IGF tanto en el oviducto como en las glándulas endometriales del útero, sugiere que el IGF-1 endócrino podría tener un importante efecto indirecto a través de alteraciones de las secreciones del tracto reproductivo, de lo cual depende la supervivencia del embrión (Fenwick y col., 2008).

En todas las especies estudiadas, la producción local de IGF-2 parece ser el principal regulador del crecimiento de la placenta (Forbes y Westwood, 2008) y se ha demostrado que es un potente estimulador del crecimiento fetal (Gicquel y Le Bouc, 2006).

Las modificaciones en la dieta alteran de forma significativa las concentraciones séricas de IGF-1 (O’Callaghan y col., 2000), siendo éste más sensible a cambios nutricionales que el IGF-2 (Thissen y col., 1994). Se ha demostrado que las concentraciones plasmáticas de IGF-1 disminuyen en ovejas sometidas a un estado de restricción nutricional (Hua y col., 1995). Durante períodos de subnutrición, cuando la insulina y la LH están reducidas, un descenso en el mecanismo inhibitorio sobre la producción intraovárica de IGF-1, puede 
ayudar a la continuidad de la función folicular, por manutención de los niveles intrafoliculares de IGF-1. Contrariamente, los autores afirman que, durante períodos de estrés, cuando los niveles sistémicos de cortisol están elevados, un aumento en el mecanismo inhibitorio sobre la producción intraovárica de IGF-1, puede contribuir a la reducción de la función reproductiva. La relevancia fisiológica de la acción de la GH sobre la esteroideogénesis folicular no se conoce con claridad; sin embargo, sí está claro que dicha hormona influye tanto en la esteroideogénesis folicular como en la foliculogénesis a través de su estímulo sobre la producción de insulina y de IGF-1 (Gong y col., 1993). La GH estimula la producción de IGFs, tanto a nivel hepático aumentando el IGF-1 circulante como a nivel ovárico y uterino, mejorando, por un lado, el desarrollo del conceptus y por otro, induciendo la transformación de células luteales chicas en grandes, lo que aumenta la producción de $\mathrm{P}_{4}$. La asociación entre el IGF-1 y la GH se ve afectada en ovejas subnutridas, resultando en una disminución de las concentraciones circulantes de IGF-1, a pesar de las altas concentraciones de GH, evidenciando el "desacople del eje GH/IGF-1” (Thissen y col., 1994). Asimismo, ovejas en un estado corporal inferior a 2,0 presentaron menores concentraciones séricas de IGF-1 que aquéllas con una condición corporal de 3,0 puntos (Caldeira y col., 2007a). En ovejas sometidas a flushing nutricional se observó una disminución de GH, pero las concentraciones de IGF-1 no se vieron modificadas (Scaramuzzi y col., 2006). Sin embargo, Caldeira y col. (2007b) evidenciaron un aumento de las concentraciones de IGF-1 cuando a ovejas en distinto estado corporal se les suministraba una dieta con el $200 \%$ de sus requerimientos de mantenimiento. Elevadas concentraciones de IGF-1 están asociadas con un incremento en las concentraciones de estradiol y son 
importantes no solamente para el desarrollo folicular, sino también para promover de forma directa la supervivencia de los espermatozoides en el tracto femenino y del embrión precoz; y en forma indirecta aumentando las secreciones del oviducto y del útero (Lenz Souza y col., 2007).

La leptina es una proteína de $16 \mathrm{kDa}$ producida por el gen de la obesidad (ob). El nombre de la leptina proviene del griego leptos, que significa "delgado" (Friedman y Halaas, 1998), también es conocida como proteína $O B$. Fue descubierta en 1994 y se la consideró como la hormona de la anti-obesidad (Zhang y col., 1994). Es una hormona producida en su mayoría por los adipocitos, aunque también se expresa en el hipotálamo, el ovario y la placenta (Chemineau y col., 1999). Las concentraciones plasmáticas de leptina reflejan la cantidad de tejido adiposo en el cuerpo y tienden a aumentar y disminuir con la ganancia y pérdida de peso, respectivamente. La leptina actúa sobre un número de neuropéptidos y receptores en el hipotálamo para regular el apetito y el balance de energía en roedores, humanos y en grandes animales (Barb y Kraeling, 2004). Además, ejerce un rol importante en el nivel de otros ejes neuroendocrinos y en especial del gonadal (Ahima y col., 1997; Chehab y col., 1997). En rumiantes domésticos como bovinos y ovinos, la leptina interviene significativamente en la regulación del eje reproductivo y en la disponibilidad y metabolismo de energía. La síntesis de leptina es muy sensible a cambios en el estado metabólico, aumentando frente a la sobrealimentación o suplementación y disminuyendo frente a la subnutrición o ayuno (Chilliard y col., 2005). En ovejas subnutridas, la concentración plasmática de leptina fue significativamente menor que en las ovejas controles (Sosa y col., 
2009a). En cambio, en ovejas sometidas a flushing nutricional, se evidenció un incremento en las concentraciones de leptina (Scaramuzzi y col., 2006). Los receptores de leptina han sido localizados en el eje hipotálamo-hipófisis-ovario y en el tracto reproductivo, vinculando así, a la leptina con la reproducción (Moschos y col., 2002). En ovejas, la expresión de leptina ha sido descripta en el ovario (Muñoz-Gutiérrez y col., 2005) y en la placenta (Buchbinder y col., 2001), aunque todavía no ha sido demostrada su presencia o la de su receptor en el útero. En ratas se demostró que la leptina añadida al medio de cultivo promueve el crecimiento del embrión en la etapa de pre-implantación (Kawamura y col., 2002). En rumiantes, la relación de la leptina con el desarrollo embrionario aún no ha sido estudiada.

En síntesis, la eficiencia reproductiva es uno de los factores más relevantes que determina la eficiencia productiva y económica en los sistemas de explotación ovina (Azzarini, 2002), experimentando generalmente bajos valores en la cría extensiva (Azzarini, 1992). Estos bajos valores plantean la necesidad de conocer y cuantificar los principales factores que determinan una baja eficiencia para generar alternativas tecnológicas que permitan expresar el potencial genético de las razas ovinas. Entre los factores que repercuten directamente sobre los resultados reproductivos, se destacan las pérdidas reproductivas durante la preñez. Se conoce que el origen y la intensidad de las pérdidas durante la gestación varían de una región a otra, a partir de un estudio realizado en el Sur de Australia, donde Kleemann y Walker (2005a) destacan la necesidad de definir los problemas reproductivos para cada región. A nivel regional patagónico, la información generada en el tema es muy escasa, no disponiéndose de referencias en cuanto a la 
magnitud de sus efectos, ni a su interacción con factores como nutrición, sanidad o condiciones ambientales.

Las pérdidas prenatales pueden ocurrir en diferentes etapas de la gestación, y aunque pueden ser pequeñas en cada etapa, sobre una base acumulativa, pueden resultar en un perjuicio considerable. En la especie ovina hasta un $40 \%$ de las ovulaciones, no se corresponden con embriones viables al día 12 de la gestación (Ashworth, 1995). La mayor parte de esta mortalidad embrionaria en la etapa de pre-implantación se debe a problemas en la señalización entre el embrión y la madre, lo que conduce a un desarrollo asincrónico, con retraso en el crecimiento del embrión (Goff, 2002). El estado nutricional del animal es uno de los factores más importantes que afecta la función reproductiva en la hembra, ya que sus acciones pueden ser ejercidas en todos los niveles de control reproductivo. Tanto la subnutrición como la sobrealimentación provocan alteraciones en el medio uterino materno que impiden un adecuado desarrollo del embrión, afectando su viabilidad (Jimeno y col., 2002). En rumiantes, se ha visto que el estado nutricional se interrelaciona con el sistema reproductivo por vía de un complejo sistema de señales bioquímicas, que involucran tanto a los nutrientes como a las hormonas. Entre ellas se han identificado principalmente a la insulina, los factores de crecimiento insulínicos (IGFs) y a la leptina. Sin embargo, las diferentes aproximaciones al estudio de la relación entre la nutrición y la reproducción (diferencias en el ambiente, edad y raza de los animales, composición de las dietas, duración de los tratamientos nutricionales y el momento de su implementación con respecto al ciclo sexual) hacen que los múltiples resultados publicados a veces parezcan contradictorios y que su comparación e interpretación sean difíciles. Por 
lo tanto, el objetivo de este estudio fue caracterizar en una primera etapa las pérdidas embrionarias y fetales que ocurren en una majada de ovejas Merino en condiciones de cría extensiva en el área geográfica de Sierras y Mesetas Occidentales de la provincia de Río Negro (Capítulo II). En una segunda etapa, se evaluó el efecto del estado nutricional de las majadas ovinas, determinando la incidencia de este sobre las pérdidas reproductivas durante las etapas de la gestación (embrionaria y fetal), y estableciendo frente a qué condición corporal materna es necesario el uso de la técnica de suplementación, con el propósito de disminuir las pérdidas prenatales y la finalidad de aumentar el porcentaje de señalada (Capítulo III). En una tercera etapa se utilizó un modelo de transferencia embrionaria con el objetivo de evaluar si las fallas reproductivas asociadas al estado nutricional de la madre se deben a factores del embrión, maternos o ambos, estudiando para ello las alteraciones producidas por el tratamiento nutricional en el estado endocrinometabólico materno, la calidad embrionaria y la expresión génica uterina (Capítulo IV). 


\section{I.3 OBJETIVO GENERAL}

Evaluar las pérdidas reproductivas de la preñez en una majada general de ovejas Merino en condiciones de cría extensiva y establecer su relación con el estado nutricional materno.

\section{I.4 HIPÓTESIS DE TRABAJO}

En ovejas Merino en condiciones de cría extensiva las pérdidas reproductivas de la preñez son influenciadas por el estado nutricional materno durante los estadios iniciales de la gestación. 


\section{CAPITULO II}

\section{CARACTERIZACIÓN DE LAS PÉRDIDAS DE GESTACIÓN EN OVEJAS MERINO EN CONDICIONES DE CRIA EXTENSIVA}

\section{II.1 INTRODUCCIÓN}

Las pérdidas gestacionales en ovinos han sido evaluadas en diferentes razas y regiones del mundo, diferenciándose múltiples causas que actúan en forma interrelacionada. Los estudios hasta la fecha muestran que, en el ganado ovino, las pérdidas embrionarias son de mayor magnitud (15-30\%) siendo las muertes durante la etapa fetal generalmente inferiores (5-7\%) (Edey, 1969; 1976; Berain, 1984; Wilkins y Croker, 1990). La información generada sobre el tema a nivel nacional es escasa, no disponiéndose de referencias en cuanto a la magnitud de sus efectos, ni a su interacción con factores como la nutrición materna.

En las majadas ovinas de nuestra región, no es habitual realizar encierres, sólo se considera hacerlo en momentos claves como la esquila y la señalada, lo cual dificulta conocer las tasas de preñez mediante un diagnóstico de gestación certero, y por lo tanto se desconocen las pérdidas de gestación que pudieran ocurrir anualmente, no siendo advertidas por el productor. Por otra parte, en estos ambientes semiáridos, los animales están sometidos a períodos de subnutrición debido a la escasez de forraje en ciertas épocas del año (otoño-invierno), coincidente con el momento en que se encuentran gestantes, lo que puede tener 
implicancia en los bajos resultados productivos anuales logrados por las explotaciones ovinas de la región Norpatagónica.

Con la finalidad de caracterizar las pérdidas de gestación y evaluar su relación con el estado nutricional materno en ovejas Merino se realizó una primera experiencia en condiciones de cría extensiva.

\section{II.2 OBJETIVOS}

Los objetivos de este capítulo fueron:

a. Evaluar las pérdidas de gestación que se producen en una majada general de ovejas Merino en condiciones de cría extensiva.

b. Determinar la variación de las concentraciones séricas de $\mathrm{P}_{4}$, AGNE y hormonas metabólicas (GH, insulina, IGF-1 y leptina) involucradas en el mantenimiento y desarrollo de la gestación en relación con el estado corporal materno en ovinos.

\section{II.3 HIPÓTESIS}

Las hipótesis más relevantes de este capítulo fueron:

a. Las pérdidas de gestación en una majada general en condiciones de cría extensiva representan entre un 10 al $15 \%$ sobre el total de ovejas servidas.

b. Las concentraciones de $\mathrm{P}_{4}$, AGNE y hormonas metabólicas (GH, insulina, IGF-1 y leptina) varían con relación al estado corporal materno en los estadios iniciales de la preñez en ovejas Merino. 


\section{II.4 MATERIALES Y MÉTODOS}

\section{4.1 Animales y lugar de trabajo}

El experimento se realizó durante la estación reproductiva (otoño-invierno), en las instalaciones del Campo Experimental Pilcaniyeu de INTA Bariloche, provincia de Río Negro $\left(70^{\circ} 28^{\prime} 30^{\prime}\right.$ ' longitud oeste y $41^{\circ}$ latitud sur; Área de Sierras y Mesetas Occidentales, Patagonia Norte).

El cuidado y el tratamiento de los animales experimentales se realizaron de acuerdo con las directrices emitidas por la National Academy of Science, Washington DC, EE. UU. (National Research Council, 2011) y aprobadas por el Comité de Principios Rectores Internacionales para la Investigación Biomédica de Animales de Laboratorio (Comité Institucional de Cuidado y Uso de Animales [CICUAL]) de la FCV-UNLP; Número de protocolo: 55-3-16T.

Se utilizaron ovejas adultas raza Merino $(n=150)$ de una majada general conservando heterogeneidad en cuanto a edad y estado corporal. La edad se determinó mediante cronometría dentaria $(4,6$, boca llena y medio diente) y el estado corporal se evaluó utilizando como indicador la condición corporal (CC) que se estimó, por un único observador, mediante la palpación de las apófisis vertebrales en la región del lomo en una escala del 1(emaciada) al 5 (obesa) (Russel y col., 1969, Figura II.1), ajustando al cuarto de punto. 


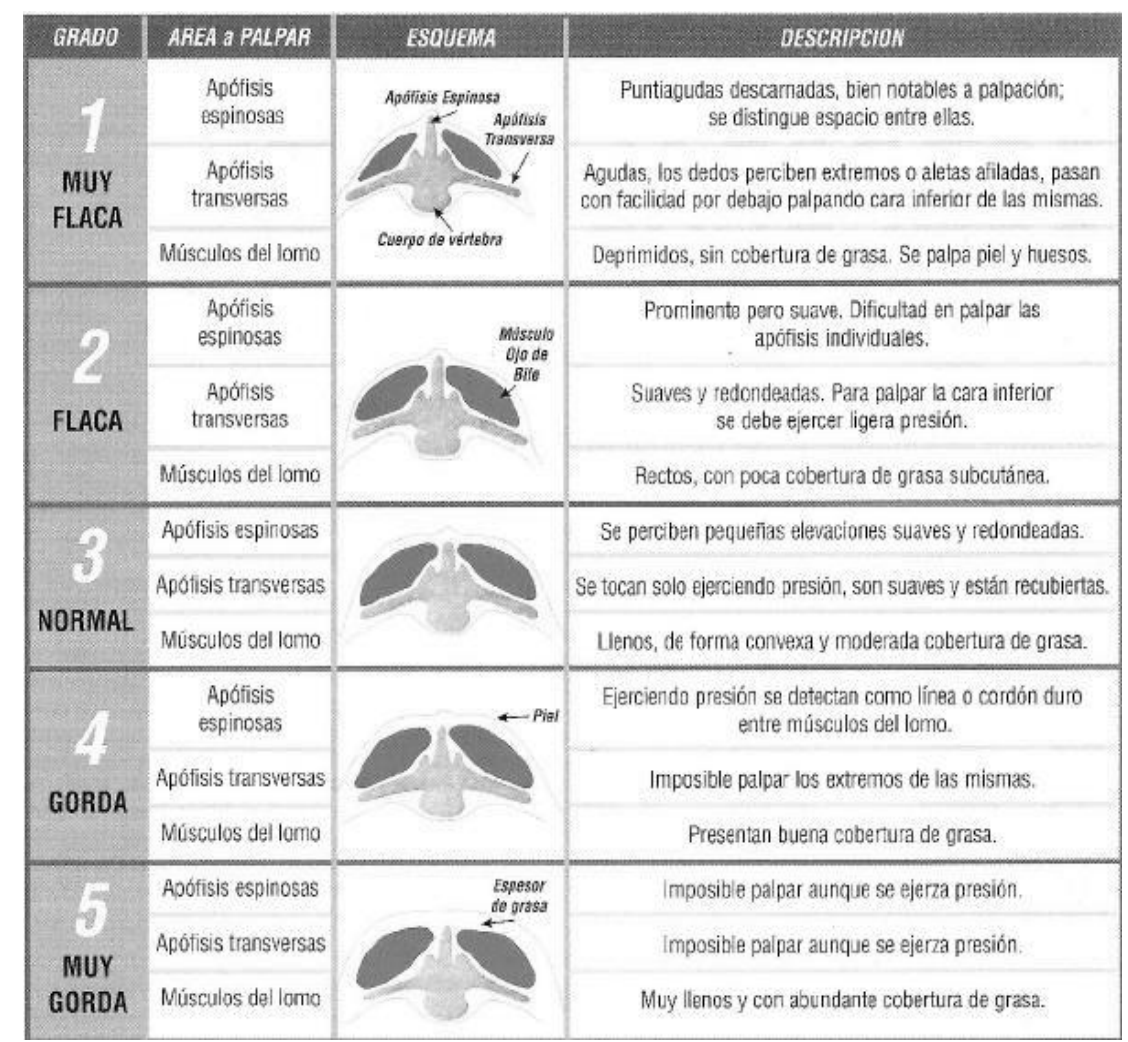

Figura II.1. Escala utilizada para la evaluación de la condición corporal en ovinos (Manazza, 2006).

\section{4.2 Condiciones de estudio y servicio a corral}

Los animales en experimentación se encontraron durante todo el período de estudio (32 días pre-servicio hasta el parto) en pastoreo sobre pastizales naturales con libre acceso al agua en un cuadro de 45,5ha. La oferta de forraje (KgMS/ha) del pastizal natural del cuadro destinado a los animales en estudio, se estimó a través del método expeditivo de evaluación forrajera de pastizales naturales (Siffredi y col., 2011), estimando la receptividad ganadera en $4 \mathrm{UGO} /$ ha (unidad ganadera ovina por hectárea).

Todas las ovejas recibieron un tratamiento de sincronización de estros mediante la colocación de esponjas intravaginales durante 14 días (acetato de medroxiprogesterona (MAP), 60 mg; Progespon, Syntex SA, Argentina). Al retiro 
de la esponja intravaginal se administró gonadotropina coriónica equina (eCG; 100 UI, Novormon, Syntex SA, Argentina) por vía intramuscular. El servicio dirigido se realizó sobre el retorno al celo (celo natural) que se manifestó entre los días 18 y 21 post retiro de la esponja intravaginal (Cueto y Gibbons, 2010). La detección de estros se realizó mediante un macho marcador con arnés, y se seleccionaron para continuar el estudio solo aquellas hembras $(n=74)$ detectadas en celo entre los días 19 y 20 post retiro de esponja que recibieron un servicio a corral con carneros adultos (Día 0 de gestación). Se utilizó un total de 8 machos adultos de la raza Merino, de comprobada capacidad de servicio y clínicamente sanos (Revisación clínica apta y prueba negativa a Brucella ovis).

\section{4.3 Determinación de peso vivo y condición corporal}

El PV y la CC se determinaron en los animales en experimentación al inicio del tratamiento progestacional, al servicio y al día 35 post servicio (día -32, 0 y 35; día $0=$ servicio natural). Las ovejas fueron clasificadas según su estado corporal mediante la utilización de la $\mathrm{CC}$ al servicio; ovejas con baja condición corporal (CC $\leq 2,00)$ y ovejas con alta condición corporal $(\mathrm{CC} \geq 2,25)$.

\section{4.4 Toma de muestras}

La extracción de sangre por venopunción yugular se realizó en todas las ovejas incluidas en el experimento los días $-32( \pm 1), 0,7,14,17,21,28$ y 35 con respecto al día del servicio natural, utilizando tubos de 10ml (BD Vacutainer ${ }^{\circledR}$, Franklin Lakes, NJ, USA). Todas las muestras fueron centrifugadas (1000g por 10 
minutos) y el suero obtenido, se almacenó a $-20^{\circ} \mathrm{C}$ hasta el momento de los análisis de metabolitos y hormonas.

\section{4.5 Determinación de $\mathrm{P}_{4}$}

Las muestras de suero obtenidas de todas las ovejas en los días 17, 21 y 28 post servicio, fueron utilizadas para determinar la concentración sérica de $\mathrm{P}_{4}$ por radioinmunoensayo (RIA) (Coat-A-Count ${ }^{\circledR}$ Progesterone, Diagnostic Product Corporation, Los Angeles, USA). La concentración de $\mathrm{P}_{4}$ al día 17 fue aceptada como diagnóstico precoz de gestación utilizando como valor de corte $1 \mathrm{ng} / \mathrm{ml}$ (ovejas no preñadas $<1 \mathrm{ng} / \mathrm{ml}$; ovejas preñadas, >1ng/ml; McPhee y Tiberghien, 1987; Thimonier, 2000).

\section{4.6 Determinación de metabolitos y hormonas metabólicas}

Se seleccionó una subpoblación de ovejas con diagnóstico de preñez al día 35 positivo y negativo, de forma aleatoria $(n=32)$ para realizar la determinación de metabolitos y hormonas metabólicas. De esta manera, en forma retrospectiva, se utilizaron las muestras de suero obtenidas de estas ovejas en los días $-32( \pm 1), 0,7$, 14, 21, 28 y 35 para realizar la determinación de las concentraciones séricas de AGNE, kit NEFA-HR2, Wako Chemicals, Richmond, USA; Giuliodori y col., 2011) con el fin de estimar el balance energético de los animales en estudio. Los coeficientes de variación intraensayo e inter-ensayo fueron de 5,7 y 7,8\%, respectivamente. Asimismo, se determinaron las concentraciones séricas de las hormonas metabólicas GH, insulina, IGF-1 y leptina mediante RIAs validados previamente (Becú-Villalobos y col., 2007; Díaz-Torga y col., 2001; Lacau- 
Mengido y col., 2000). El RIA de IGF-1 se realizó, previa extracción en etanolácido y crio-precipitación, con anticuerpo para IGF-1 (UB2-495, Hormone Distribution Program of the NIDDK). Los coeficientes de variación intra- e interensayo fueron de 7,2 y 8,8\%, respectivamente. El RIA de insulina se realizó con anticuerpo anti-insulina bovina de Sigma (St.Louis, Missouri, USA) e insulina provista por Laboratorios Beta (Buenos Aires, Argentina) como standard. Los coeficientes de variación intra- e inter-ensayo fueron de 6,8 y $8,9 \%$, respectivamente. Para el RIA de GH se usó el anticuerpo anti oGH y como standard oGH, ambos del NIDDK. Por último, el RIA de leptina se realizó con el método del doble anticuerpo, con antisuero específico ovino (Delavaud y col., 2002) y leptina recombinante bovina como standard (DS Labs, Webster, Texas, USA, BecúVillalobos y col., 2007). Los coeficientes de variación intra- e inter-ensayo fueron de 6,7 y 9,0\%, respectivamente. La concentración de las hormonas metabólicas se expresa en $\mathrm{ng} / \mathrm{ml}$.

\section{4.7 Diagnóstico de gestación y pérdidas gestacionales}

El diagnóstico de gestación mediante ecografía transrectal se realizó en todos los animales al día 35, 60, 90 y 120 post-servicio utilizando un transductor lineal de 5 MHz (Aloka SSD-500, Tokyo, Japón).

Las pérdidas embrionarias tardías ocurridas entre los días 17 y 35 de gestación se evaluaron por diferencia entre el diagnóstico de gestación por determinación de las concentraciones séricas de $\mathrm{P}_{4}$ al día 17 y el diagnóstico de gestación por ecografía transrectal al día 35, en todas las ovejas servidas. Las 
pérdidas fetales se evaluaron en tres intervalos comprendidos entre los días 35-60, 60-90 y 90-120 de gestación, considerando las diferencias entre los diagnósticos de gestación por ecografía transrectal. Las pérdidas de gestación producidas entre los días 120 y 150 de gestación se determinaron al parto mediante el control de parición.

\section{4.8 Análisis estadístico}

El PV, la CC y las concentraciones séricas de $\mathrm{P}_{4}, \mathrm{GH}$, insulina, IGF-1, leptina y AGNE fueron analizadas con un modelo de mediciones repetidas en el tiempo utilizando el procedimiento MIXED de SAS (SAS, 2003) considerando diferencias según el DG (positivo, negativo) y la CC (baja $\leq 2,00$; alta $\geq 2,25$ ). Las medias de los grupos se compararon por Test de Tukey. La significancia estadística fue aceptada con un $\mathrm{P}<0,05$ y una tendencia a la significancia fue aceptada con un $\mathrm{P}<0,1$. 


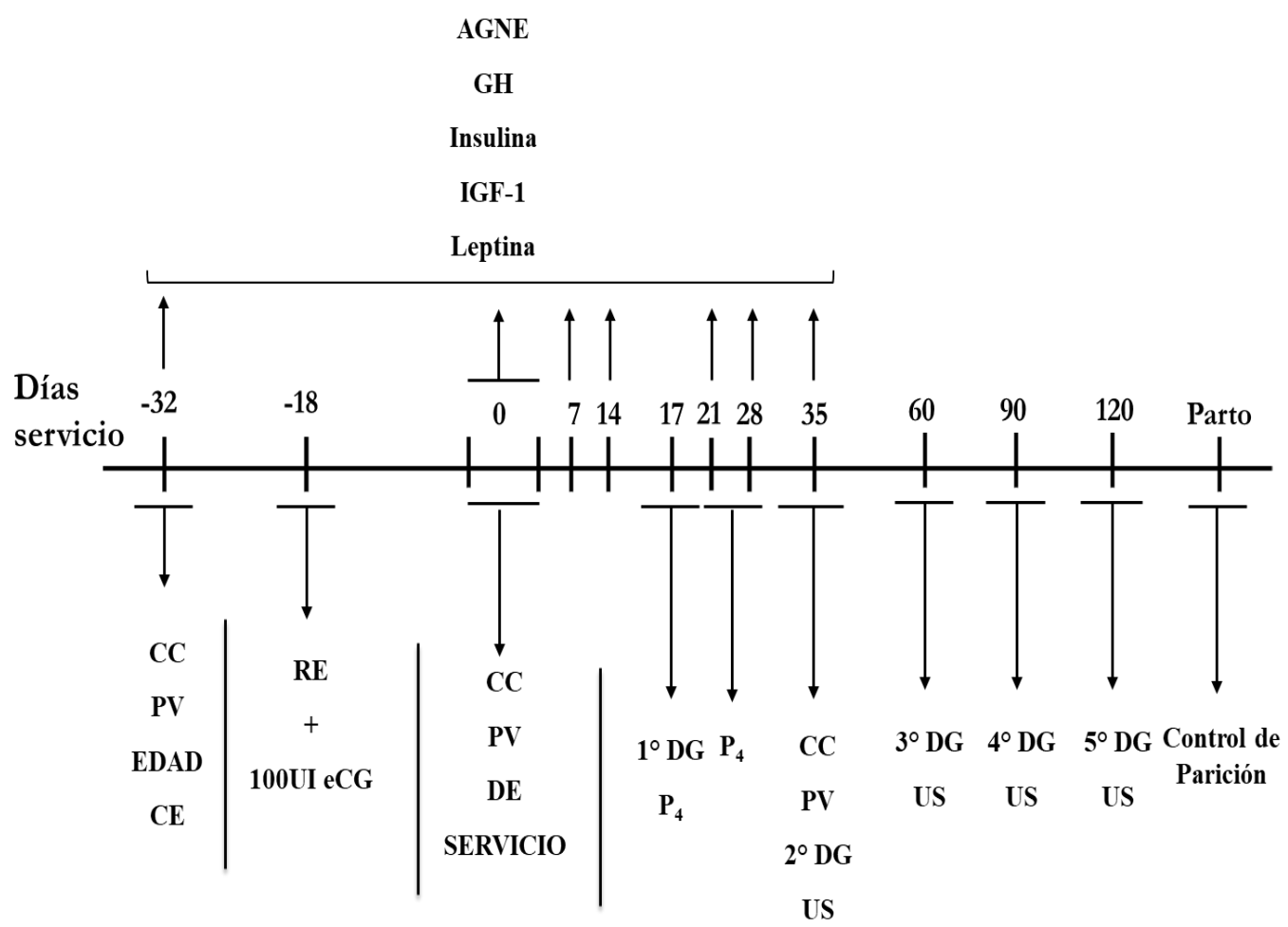

Figura II.2. Cronograma de actividades para caracterizar las pérdidas de gestación en ovejas Merino. CE, colocación de esponjas intravaginales; eCG, gonadotrofina coriónica equina; $\mathrm{RE}$, retiro de esponjas; CC, condición corporal; $\mathrm{PV}$, peso vivo; $\mathrm{DE}$, detección de celos; AGNE, ácidos grasos no esterificados; GH, hormona de crecimiento; IGF-1, factor de crecimiento similar a la insulina tipo 1; $\mathrm{P}_{4}$, progesterona; $\mathrm{DG}$, diagnóstico de gestación; US, ultrasonografía.

\section{II.5 RESULTADOS}

\section{5.1 Sincronización de celo y servicio}

El 60,7\% (91/150) de las ovejas en estudio presentaron celo entre los días 18 y 21 post retiro de esponja (Figura II.3), el 81,3\% (74/91) de éstas recibieron servicio natural dirigido entre los días 19 y 20 post retiro de esponja y fueron 
seleccionadas para realizar el seguimiento de gestación desde el servicio hasta el parto.

Las hembras que manifestaron celo presentaron mayores promedios de PV y CC al inicio del tratamiento progestacional (PV, 41,99 $\pm 0,57 \mathrm{~kg} ; \mathrm{CC}, 2,14 \pm 0,02$ ) en comparación con aquellas ovejas que no manifestaron estro (PV, 37,48 $\pm 0,75 \mathrm{~kg}$; $\mathrm{CC}, 1,93 \pm 0,03)(\mathrm{P}<0,0001)$.

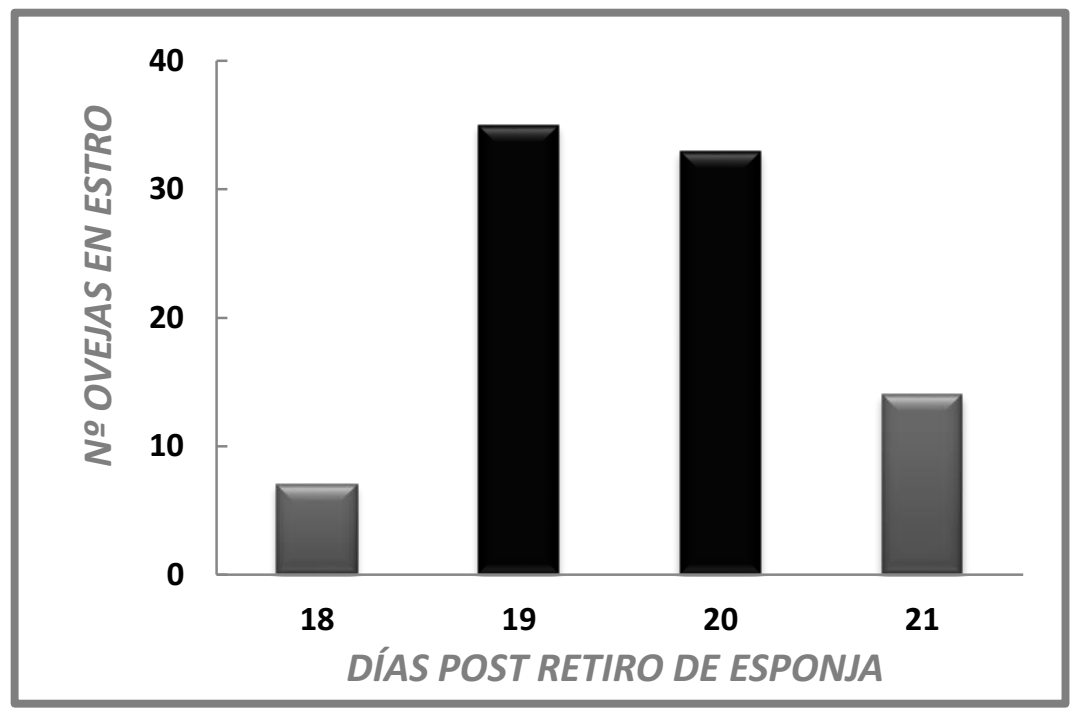

Figura II.3. Distribución diaria de hembras ovinas que presentaron estros retornos entre los días 18 y 21 post retiro de esponja intravaginal con progestágenos. 


\section{5.2 Estado corporal y edad sobre la tasa de preñez}

No hubo influencia del estado corporal ni de la edad $(4,6$, boca llena y medio diente) sobre la tasa de preñez diagnosticada al día 35 post servicio.

El PV y CC de las ovejas que recibieron servicio entre los días 19 y 20 post retiro de esponjas no presentó cambios entre el inicio del tratamiento progestacional (Día -32), el servicio (Día 0) y el día 35 post servicio (Tabla II.1), observándose que las ovejas iniciaron el tratamiento progestacional con una $\mathrm{CC}$ relativamente baja $(2,1)$.

Tabla II.1. Peso vivo y condición corporal (MMC \pm ES) de ovejas al inicio del tratamiento progestacional (Día -32), al servicio (Día 0) y al día 35 post servicio.

Superíndices en una misma fila indican diferencias significativas $(\mathrm{P}<0,05)$.

\begin{tabular}{cccc}
\hline & $\begin{array}{c}\text { Día }-32 \\
\text { Pre servicio }\end{array}$ & $\begin{array}{c}\text { Día 0 } \\
\text { Servicio }\end{array}$ & $\begin{array}{c}\text { Día 35 } \\
\text { Post servicio }\end{array}$ \\
\hline Peso Vivo $(\mathrm{Kg})$ & $42,1 \pm 0,70^{\mathrm{a}}$ & $42,1 \pm 0,66^{\mathrm{a}}$ & $41,0 \pm 0,62^{\mathrm{a}}$ \\
Condición Corporal & $2,13 \pm 0,03^{\mathrm{a}}$ & $2,13 \pm 0,03^{\mathrm{a}}$ & $2,13 \pm 0,03^{\mathrm{a}}$ \\
\hline
\end{tabular}

\section{II.5.3 Diagnóstico de gestación y pérdidas gestacionales}

El análisis de las concentraciones séricas de $\mathrm{P}_{4}$ en el total de las ovejas que recibieron servicio dirigido a corral determinó una tasa de preñez del 82,4\% (61/74) al día 17 post servicio. Mediante el diagnóstico de gestación por ultrasonografía transrectal al día 35, se determinó un 81,1\% (60/74) de ovejas preñadas, manifestándose un $1,64 \%$ de pérdidas embrionarias entre el día 17 y 35 de gestación. Las pérdidas gestacionales totales ocurridas entre el primer diagnóstico de gestación al día 17 y el parto fueron del 3,27\%, manifestándose esta segunda pérdida por mortalidad fetal entre el día 35 y 60 de gestación. 


\section{II.5.4 Progesterona}

Mediante el análisis de los tres muestreos correlativos de $\mathrm{P}_{4}$, las ovejas se caracterizaron en: ovejas no preñadas no cíclicas o cíclicas, y ovejas preñadas que mantuvieron su gestación o presentaron pérdidas embrionarias, diferenciándose estadísticamente las concentraciones promedio de $\mathrm{P}_{4}$ entre los 4 grupos de hembras $(\mathrm{P}<0,0001$, Tabla II.2).

Tabla II.2. Concentración sérica (MMC \pm ES) de $\mathrm{P}_{4}$ entre los días 17 y 28 post servicio, en ovejas no preñadas (no cíclicas, cíclicas) y ovejas preñadas ( $\sin$ y con pérdidas embrionarias) al día 35 post servicio.

\begin{tabular}{ccccc}
\hline & \multicolumn{2}{c}{ No preñadas } & \multicolumn{2}{c}{ Preñadas } \\
\hline $\begin{array}{c}\text { No cíclicas } \\
(\mathrm{n}=3)\end{array}$ & $\begin{array}{c}\text { Cíclicas } \\
(\mathrm{n}=10)\end{array}$ & $\begin{array}{c}\text { Sin pérdidas } \\
\text { embrionarias } \\
(\mathrm{n}=60)\end{array}$ & $\begin{array}{c}\text { Con pérdidas } \\
\text { Embrionarias } \\
(\mathrm{n}=1)\end{array}$ \\
\hline $\mathbf{P}_{\mathbf{4}}(\mathbf{n g} / \mathbf{m l})$ & $0,21 \pm 0,63^{\mathrm{a}}$ & $2,31 \pm 0,34^{\mathrm{b}}$ & $6,58 \pm 0,14^{\mathrm{c}}$ & $9,50 \pm 1,09^{\mathrm{d}}$ \\
\hline
\end{tabular}

Superíndices en la misma fila indican diferencias significativas $(\mathrm{P}<0,0001)$.

A su vez, al agrupar las ovejas en no preñadas y preñadas al día 17 y día 35 de gestación, se evidenció que la concentración de $\mathrm{P}_{4}$ en los días 17, 21 y 28 post servicio fue mayor en las ovejas preñadas vs. las ovejas no preñadas $(\mathrm{P}<0,05)$; esta diferencia se mantuvo en el día 28 post servicio, aun cuando las ovejas no preñadas se encontraban en la fase luteal del ciclo estral (Tabla II.3). 
Tabla II.3. Concentración sérica (MMC $\pm \mathrm{ES}$ ) de $\mathrm{P}_{4}$ en los días 17, 21 y 28 post servicio en ovejas preñadas y no preñadas al día 17 (DG 17) y día 35 (DG 35) de gestación.

\begin{tabular}{ccccc}
\hline \multicolumn{4}{c}{ Progesterona $(\mathrm{ng} / \mathrm{ml})$} \\
\hline $\begin{array}{c}\text { Días } \\
\text { Post } \\
\text { servicio }\end{array}$ & $\begin{array}{c}\text { No preñadas } \\
(\mathrm{n}=13)\end{array}$ & $\begin{array}{c}\text { Preñadas } \\
(\mathrm{n}=61)\end{array}$ & $\begin{array}{c}\text { No preñadas } \\
(\mathrm{n}=14)\end{array}$ & $\begin{array}{c}\text { Preñadas } \\
(\mathrm{n}=60)\end{array}$ \\
\cline { 2 - 5 } 17 & $0,39 \pm 0,51^{\mathrm{a}}$ & $6,83 \pm 0,24^{\mathrm{b}}$ & $1,10 \pm 0,57^{\mathrm{a}}$ & $6,77 \pm 0,28^{\mathrm{b}}$ \\
21 & $0,64 \pm 0,47^{\mathrm{a}}$ & $6,40 \pm 0,21^{\mathrm{b}}$ & $1,42 \pm 0,50^{\mathrm{a}}$ & $6,32 \pm 0,23^{\mathrm{b}}$ \\
28 & $4,44 \pm 0,49^{\mathrm{a}}$ & $6,65 \pm 0,24^{\mathrm{b}}$ & $4,60 \pm 0,49^{\mathrm{a}}$ & $6,65 \pm 0,24^{\mathrm{b}}$ \\
\hline
\end{tabular}

Superíndices en la misma fila indican diferencias significativas $(\mathrm{P}<0,05)$.

DG: diagnóstico de gestación.

Al considerar la concentración de $\mathrm{P}_{4}$ según la clasificación de las ovejas por su estado corporal al servicio (baja $=\leq 2,00$ y alta $=\geq 2,25$ ), se observó que las ovejas preñadas con alta $\mathrm{CC}$ presentaron menores concentraciones de $\mathrm{P}_{4}$ entre los días 17 y 28 post servicio con respecto a las ovejas con baja $\mathrm{CC}(\mathrm{P}<0,001)$. Sin embargo, esta diferencia en la concentración de $\mathrm{P}_{4}$ según la $\mathrm{CC}$ al servicio no se evidenció en ovejas no preñadas $(\mathrm{P}<0,0001$, Tabla II.4).

Tabla II.4. Concentración sérica (MMC $\pm \mathrm{ES}$ ) de $\mathrm{P}_{4}$ del día 17 al 28 entre ovejas no preñadas y preñadas al día 35 post servicio según la $\mathrm{CC}$ al servicio (baja $=\leq 2,00$ y alta $=\geq 2,25$ ).

\begin{tabular}{ccccc}
\hline & \multicolumn{2}{c}{ No preñadas } & \multicolumn{2}{c}{ Preñadas } \\
\hline $\begin{array}{c}\text { CC baja } \\
(\mathrm{n}=6)\end{array}$ & $\begin{array}{c}\text { CC alta } \\
(\mathrm{n}=8)\end{array}$ & $\begin{array}{c}\text { CC baja } \\
(\mathrm{n}=50)\end{array}$ & $\begin{array}{c}\text { CC alta } \\
(\mathrm{n}=10)\end{array}$ \\
\hline $\mathrm{P}_{4}(\mathrm{ng} / \mathrm{ml})$ & $2,24 \pm 0,49^{\mathrm{a}}$ & $2,47 \pm 0,43^{\mathrm{a}}$ & $6,72 \pm 0,17^{\mathrm{b}}$ & $5,87 \pm 0,38^{\mathrm{c}}$
\end{tabular}

Superíndices en la misma fila indican diferencias significativas $(\mathrm{P}<0,0001)$. 


\section{II.5.5 Metabolitos y hormonas metabólicas}

En este estudio de caracterización en ovejas en pastoreo extensivo, la CC al servicio evidenció un efecto sobre las concentraciones de GH, siendo más elevada en ovejas con baja $\mathrm{CC}(4,18 \pm 0,44 \mathrm{ng} / \mathrm{ml})$ respecto a las de alta $\mathrm{CC}(2,32 \pm 0,38$ $\mathrm{ng} / \mathrm{ml}) \quad(\mathrm{P}<0,001)$; sin embargo, no tuvo efecto significativo sobre las concentraciones séricas de AGNE, insulina, IGF-1 y leptina durante las semanas pre y post servicio analizadas (Figura II.4 y II.5).

Las ovejas no preñadas presentaron mayores concentraciones séricas de insulina $(0,86 \pm 0,04 \mathrm{ng} / \mathrm{ml})$ y leptina $(0,77 \pm 0,03 \mathrm{ng} / \mathrm{ml})$ que las ovejas preñadas $(0,76 \pm 0,03 \mathrm{ng} / \mathrm{ml} ; 0,66 \pm 0,02 \mathrm{ng} / \mathrm{ml}$, respectivamente; $\mathrm{P}<0,05)$. El diagnóstico de gestación al día 35 post servicio no evidenció efecto sobre las concentraciones de AGNE, GH e IGF-1 (P>0,05, Figura II.4 y II.5).
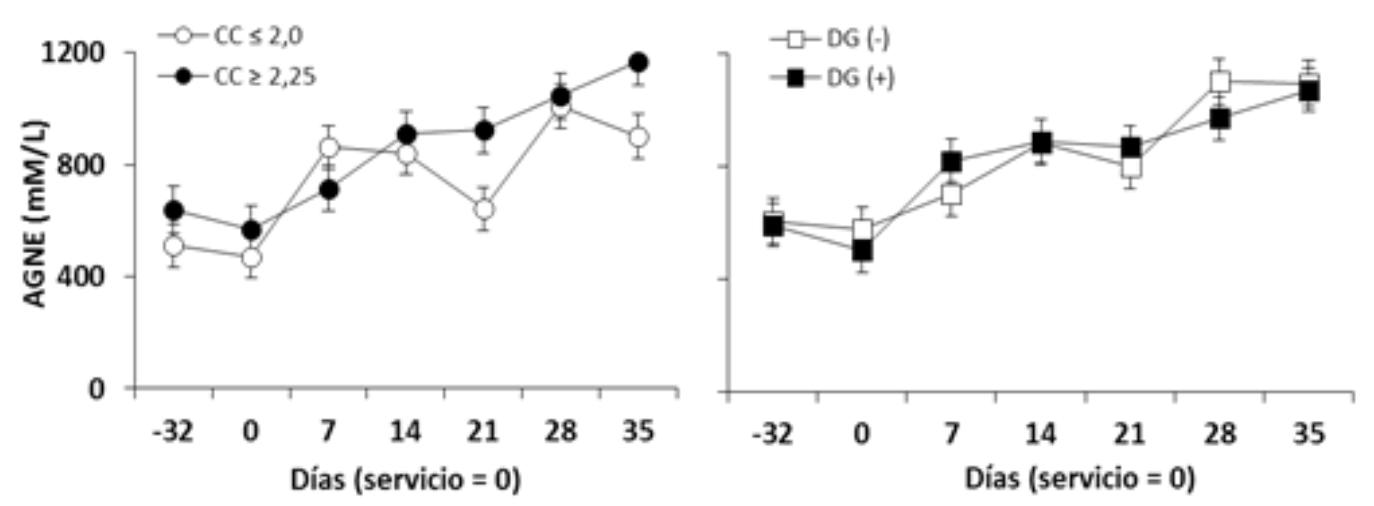

Figura II.4. Concentración sérica de ácidos grasos no esterificados (AGNE; $\mathrm{MMC} \pm \mathrm{ES}$ ), en relación con la condición corporal (CC) (panel izquierdo) y el diagnóstico de gestación (DG) (panel derecho) en ovejas Merino en pastoreo entre los días -32 y 35 del servicio. 

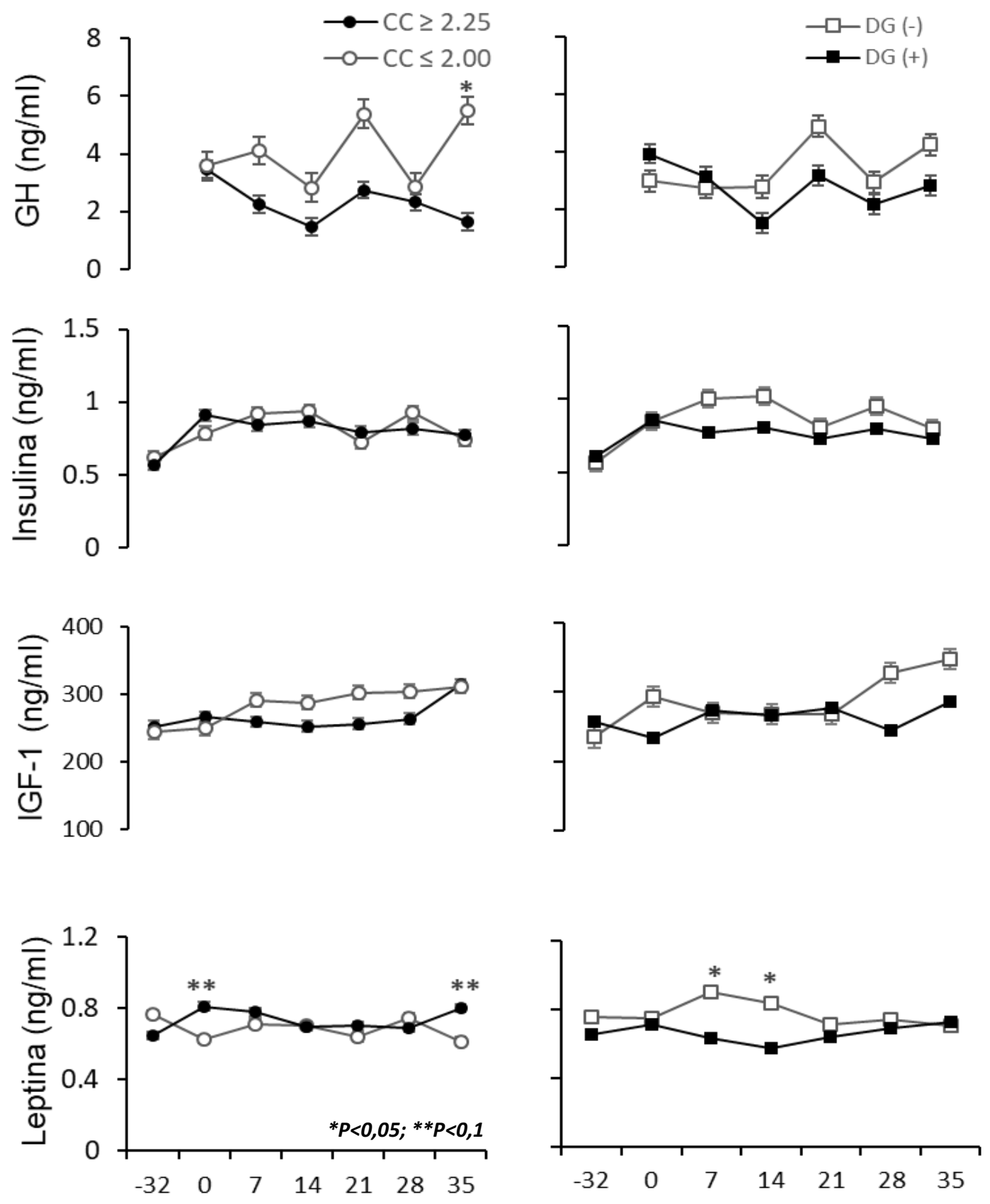

Días $(0$ - Servicio $)$

Figura II.5. Concentraciones séricas $(\mathrm{MMC} \pm \mathrm{ES})$ de la hormona de crecimiento (GH), de insulina, del factor de crecimiento similar a la insulina tipo 1 (IGF-1) y de leptina, en relación con la condición corporal (CC) (panel izquierdo) y el diagnóstico de gestación (DG) (panel derecho) en ovejas Merino en pastoreo entre los días -32 y 35 del servicio. 


\section{II.6 DISCUSIÓN}

\section{Presentación de estros y tasa de preñez según la CC al servicio}

En el presente estudio el porcentaje de presentación del estro sobre la totalidad de las ovejas sincronizadas en sus estros fue menor (61\%), en comparación con estudios anteriores en los cuales, mediante un tratamiento progestacional más 100UI de eCG, el 85\% de las ovejas Merino manifestaron celo retorno entre los 18 y 21 días post retiro de esponja (Cueto y Gibbons, 2010). La alta tasa de sincronización obtenida por Cueto y Gibbons en el estudio anterior fue alcanzado utilizando majadas ovinas con $\mathrm{CC}$ superiores a los 2,5 puntos. A diferencia del citado trabajo, las ovejas de nuestro estudio se encontraban con una CC promedio de 2,1 puntos al inicio del tratamiento progestacional, que se mantuvo sin cambios hasta el momento de la detección de estros, pudiendo afectar la manifestación del celo retorno de la majada en estudio.

Por otra parte, el análisis del PV y la $\mathrm{CC}$ al inicio del tratamiento progestacional evidenció una diferencia significativa en el PV $(4,5 \mathrm{Kg})$ y la CC $(0,2$ puntos) a favor de las ovejas que manifestaron celo en comparación con aquellas ovejas que no presentaron estro entre los 18 y 21 días post retiro de esponja. Numerosos estudios acompañan estos resultados donde el proceso de manifestación del estro es afectado por el estado corporal de las hembras ovinas, pudiendo las mismas presentar un celo silente o permanecer en estado de anestro ante la carencia de nutrientes en la temporada reproductiva (Gunn y Doney, 1975; Forcada y col., 1992; Gibbons, 1993; Kenyon y col., 2014). 
Durante este estudio de caracterización, las ovejas no presentaron cambios en el PV y la CC desde el inicio del tratamiento progestacional hasta el día 35 post servicio, evidenciándose que el estado corporal y la edad no influyeron sobre la tasa de preñez. A este respecto es importante señalar que, considerando la baja condición corporal promedio de las ovejas en estudio, si bien se afectó la proporción de ovejas que manifestó celo, no se afectó la proporción de ovejas preñadas, lo que destaca la gran adaptación de esta raza a las condiciones regionales. Si bien la condición corporal promedio de esta majada fue inferior a la de otras razas de ovinos o regiones del mundo, en estos ambientes semiáridos es frecuente que las ovejas se encuentren en $\mathrm{CC}$ de 2 a 2,5 puntos, dependiendo del estado del pastizal y del efecto climático del año.

\section{Pérdidas gestacionales y concentración de $P_{4}$}

El primer hallazgo importante de este estudio fue la considerablemente baja presentación de pérdidas gestacionales entre el día 17 post servicio hasta el parto (3,27\%), aun en ovejas con una CC de 2,1 al servicio, en contraposición con otros estudios que determinaron pérdidas gestacionales-fetales entre el 15 al $25 \%$ (Kleemann y Walker 2005a; Fernández Abella y Formoso, 2007). En varios estudios, Fernández Abella y col. (1992, 2006, 2007) han hecho referencia a que la fertilidad de las ovejas está estrechamente relacionada con las pérdidas embrionarias, explicando gran parte de estas en relación a la $\mathrm{CC}$, debido a su ocurrencia principalmente en ovejas con CC inferior a 2,75 puntos. Algunos autores han reportado la ocurrencia de pérdidas gestacionales cuando los animales gestantes son sometidos a situaciones de estrés nutricional (Edey, 1969; Parr y col., 1982; 
Fernández Abella y Formoso, 2007; Abecia y col., 1997). Sin embargo, en nuestro trabajo, aunque la CC promedio fue inferior a 2,5, ésta fue constante durante todas las semanas de estudio, estando los animales adaptados a su condición y evitando la ocurrencia de pérdidas gestacionales.

A pesar de que en nuestro estudio sólo se manifestó una pérdida embrionaria entre el día 17 y 35 post servicio, dicha oveja evidenció una mayor concentración de $\mathrm{P}_{4}$ en comparación con las ovejas preñadas que mantuvieron la gestación y las no preñadas cíclicas y no cíclicas. Esto es coincidente con Parr y col. (1987) quienes describieron altas tasas de mortalidad embrionaria en animales subnutridos que presentaron elevadas concentraciones de $\mathrm{P}_{4}$. Sin embargo, existen numerosos estudios que reportan mayores pérdidas embrionarias en relación con bajos niveles de $\mathrm{P}_{4}$ (Edey, 1976; Brien y col., 1981; Torres y col., 1983; Harrison y col., 1987; Ainsworth, 1987). Kleemann y col. (1991) demostraron que la suplementación con progestágenos podía reducir la mortalidad embrionaria. La respuesta a la $\mathrm{P}_{4}$ es observada en los primeros 4 a 7 días luego de la ovulación, afectando la formación del blastocito. A su vez, los bajos niveles de $\mathrm{P}_{4}$ durante los primeros días del ciclo estral podrían estar influenciando las fallas parciales (muerte de parte de los embriones) luego de ovulaciones múltiples (Fernández Abella, 1993).

Por último, se manifestó una pérdida por mortalidad fetal entre los días 35 y 60 de gestación, siendo éstas de muy baja presentación, pues no se evidenciaron pérdidas fetales en ninguno de los 2 experimentos siguientes. De igual manera otros autores han reportado baja presentación de perdidas fetales, atribuyendo su presentación principalmente en ovejas gemelares con restricción alimenticia (Kelly 
y col., 1989) o cuando el tamaño de la camada es mayor a dos (Wilkins y col., 1984).

\section{Dificultad en el diagnóstico de pérdidas embrionarias tempranas}

Es necesario considerar que según la bibliografía (Edey, 1970; Diskin y Morris, 1980) el mayor número de pérdidas de gestación ocurriría entre la segunda y tercera semana de gestación, antes de que pueda realizarse un diagnóstico certero de la presencia del embrión. Kleemann y col. (1990), trabajando con ovejas con y sin el gen Booroola, obtuvieron la mayor proporción de las pérdidas embrionarias en los primeros 21 días de gestación (54,7 y 40,3\%, respectivamente). A su vez, el $64 \%$ de dichas pérdidas ocurrían en los primeros 13 días del ciclo estral. Es necesario destacar que, en el citado estudio, el porcentaje tan alto de pérdidas embrionarias se debe a que las mismas eran contabilizadas según la diferencia entre la presencia de cuerpos lúteos y la de embriones al sacrificio, incluyendo de esta forma las fallas de fertilización. Las muertes embrionarias provocan la reabsorción total del embrión sin observación de ningún síntoma, salvo el aumento anormal del intervalo entre celos. Los embriones que mueren antes del día 12 no causan disturbios en el largo normal del ciclo, pero aquéllos que sobreviven más allá de ese tiempo previenen la regresión del cuerpo lúteo. Esto parecería estar explicado por la elongación rápida de las membranas, que comienza en el día 12, por lo que las muertes resultan en un atraso del estro debido a que la secreción del cuerpo lúteo es mantenida hasta que la reabsorción de las membranas es sustancialmente completa. La fertilidad del celo posterior a la pérdida embrionaria es menor, asociado esto a un deterioro en el transporte espermático (Fernández Abella, 1993). 
Según Edey (1976), estos problemas se verían atenuados en condiciones normales de producción, debido a que la mayoría de las muertes ocurren lo suficientemente temprano en la preñez como para permitir al menos un servicio más antes de que los carneros sean retirados. Los principales efectos serían retrasos en las pariciones, incrementos en su distribución temporal, reducción de la tasa mellicera y la aparición de algunas ovejas estériles.

La implementación de un diagnóstico de preñez temprano mediante la determinación de las concentraciones de $\mathrm{P}_{4}$ al día 17 , también utilizada por otros autores (Viñoles y col., 2012), nos permitió conocer que el 82,4\% de las ovejas se encontraban con una gestación en progreso luego de haber ocurrido el proceso de reconocimiento materno de la gestación y de implantación embrionaria. Sin embargo, desconocemos si el resultado del $17,6 \%$ de las ovejas que recibieron servicio, pero luego se diagnosticaron no preñadas por tener concentraciones de $\mathrm{P}_{4}$ $<1 \mathrm{ng} / \mathrm{ml}$, se debió a una falla en el proceso de fertilización o a pérdidas embrionarias tempranas ocurridas entre la fertilización y el día 17 post servicio. Este último resultado, dio lugar a proponer una nueva experiencia durante el segundo año, en la cual, mediante la colecta quirúrgica de embriones se cuantificará la tasa de ovulación y fertilización para una subpoblación de las ovejas en estudio. La diferencia entre la tasa de fertilización lograda y el diagnóstico de preñez temprano, utilizando las concentraciones de $\mathrm{P}_{4}$, permitiría diferenciar las pérdidas embrionarias tempranas de las fallas en el proceso de fertilización (Ver Capitulo III). 


\section{Concentraciones de $P_{4}$ en ovejas preñadas vs. no preñadas}

El análisis de las concentraciones de $\mathrm{P}_{4}$ en función del estado fisiológico evidenció que las ovejas preñadas presentaron mayores concentraciones de $\mathrm{P}_{4}$ en tres muestreos consecutivos (días 17 al 28) en comparación con las hembras no preñadas. Sin embargo, Delpino y González Stagnaro (1993) señalaron que no es posible diferenciar entre hembras que se encuentran en la fase luteal del ciclo y hembras gestantes según sus concentraciones de $\mathrm{P}_{4}$, tanto en la especie ovina como en la especie caprina. A diferencia de estos autores, un resultado interesante de este estudio fue que las ovejas con cuerpo lúteo gestacional tuvieron mayores concentraciones de $\mathrm{P}_{4}$ que aquéllas con cuerpo lúteo del ciclo estral al día 28 post servicio. Pero, esta diferencia podría explicarse por la presencia de ovejas que no iniciaron un nuevo ciclo estral entre las ovejas no preñadas, las cuales presentaron concentraciones basales de $\mathrm{P}_{4}$ durante los tres muestreos consecutivos.

\section{Concentraciones de $\mathrm{P}_{4}$ en relación con la $\mathrm{CC}$}

La relación inversa entre el estado corporal materno y los niveles séricos de $\mathrm{P}_{4}$ ha sido descripta por varios autores (Abecia y col., 1999; Lozano y col., 2003). Esto es coincidente con nuestro estudio donde las ovejas preñadas con alta CC presentaron menores concentraciones de $\mathrm{P}_{4}$ que las ovejas con baja CC. Se describe que en ovejas con elevada CC la metabolización de la $\mathrm{P}_{4}$ se acelera reflejando en sangre menores concentraciones hormonales de $\mathrm{P}_{4}$ (Parr, 1992). Sin embargo, al considerar las ovejas no preñadas, éstas no presentaron diferencias en las concentraciones de $\mathrm{P}_{4}$ según su CC. Debemos considerar que estos resultados se obtuvieron en una majada que presentó un rango de CC relativamente homogéneo 
entre 1,75 y 2,5, por lo cual en un segundo ensayo se planteó evaluar qué sucedería al incrementar la variación en el estado corporal de las ovejas (Ensayo II).

\section{Hormonas metabólicas según el estado fisiológico y la CC}

Las mayores concentraciones de $\mathrm{GH}$ en ovejas con baja $\mathrm{CC}$ observadas en este ensayo también han sido descriptas por diversos autores en ovejas con subnutrición (Chilliard y col., 1998; Thissen y col., 1994). Este efecto se debe a la menor actividad de los receptores de $\mathrm{GH}$ en hígado que provocan un desacoplamiento del eje somatotrópico (Kim, 2014). Sin embargo, en nuestro estudio el aumento de GH no fue acompañado por la disminución en las concentraciones de insulina, IGF-1 y leptina, descripta por otros autores en animales subnutridos (Sosa y col., 2006; de Brun y col., 2015), seguramente debido a que los animales no presentaron cambios en el PV y la CC durante todo el periodo de estudio.

Se observó un incremento de las concentraciones de insulina y leptina en animales no preñados al día 35 post servicio, contrariamente a otros estudios en los cuales no se ha visto un efecto de la preñez sobre la insulina o de la leptina (Kadokawa y col., 2003; Sosa y col., 2009a; de Brun y col., 2015). La diferencia en las concentraciones de insulina y leptina halladas en ese estudio entre ovejas preñadas y no preñadas podría estar evidenciando un grado moderado de subnutrición en los animales que estaban llevando adelante una gestación con CC bajas $(2,1)$. 
Resumiendo, se concluye que las pérdidas gestacionales ocurridas entre el día 17 post servicio y el parto en una majada general de ovejas Merino en condiciones de cría extensiva son de baja magnitud (3,27\%); a su vez que no se observa un efecto de la condición corporal sobre la tasa de preñez.

En base a las observaciones del Experimento I, se planteó la realización de un segundo ensayo, aplicando tratamientos de alimentación controlados para establecer una mayor diferencia entre las CC evaluadas. A su vez, con el objetivo de evaluar si aquellas ovejas que recibieron servicio, pero no presentaron preñez al día 17 post servicio $(17,6 \%)$ sufrieron una falla en el proceso de fertilización o una pérdida embrionaria temprana, propusimos un método de diagnóstico de pérdidas embrionarias tempranas mediante la recuperación quirúrgica de embriones, que nos permitiría cuantificar la tasa de fertilización para una subpoblación de las ovejas en estudio. La diferencia entre la tasa de fertilización lograda y el diagnóstico de preñez al día 17 post servicio, nos permitiría diferenciar las pérdidas embrionarias tempranas de las fallas en el proceso de fertilización. 


\section{CAPITULO III}

\section{PÉRDIDAS EMBRIONARIAS Y FETALES INFLUENCIADAS POR CAMBIOS EN LA CONDICIÓN CORPORAL MATERNA}

\section{III.1 INTRODUCCIÓN}

La relación existente entre el estado nutricional y su efecto sobre la función reproductiva en los rumiantes ha demostrado ser muy compleja, siendo objeto de numerosos estudios (Martin y col., 2004a; Abecia y col., 2006; Scaramuzzi y col., 2006). Actualmente, se dispone de mucha información de los efectos del estado nutricional sobre el eje hipotálamo hipófisis ovario, en comparación a los escasos y a veces contradictorios estudios que evalúan su efecto en el desarrollo embrionario, el medio uterino y la sobrevivencia embrionaria. Estos últimos trabajos evalúan fundamentalmente variables tales como la tasa de ovulación o la producción y calidad embrionaria con diferentes niveles de alimentación. En tanto que algunos trabajos han observado una menor tasa de ovulación en ovejas subnutridas (Rhind y col., 1989a), otros autores no evidenciaron estas diferencias (Kakar y col., 2005). Se ha descripto que la calidad ovocitaria (en cuanto a morfología) en las ovejas subnutridas es inferior a la de las ovejas control (Lozano y col., 2003). Esta menor calidad de los ovocitos recolectados también ha sido hallada en ovejas con sobrealimentación (McEvoy y col., 1998).

El proceso de implantación y desarrollo de los embriones puede verse alterado ante cambios en el estado nutricional materno debido a modificaciones en las concentraciones de hormonas metabólicas. Entre ellas se mencionan GH, 
insulina e IGF-1 (Abecia y col., 1999; Sosa y col., 2009a; Fernández Foren y col., 2019). Asimismo, es conocida la necesidad de contar con concentraciones adecuadas de $\mathrm{P}_{4}$ durante el desarrollo embrionario temprano para garantizar la funcionalidad del CL y asegurar el desarrollo y mantenimiento de la gestación (Spencer y col., 2004).

Los efectos de la nutrición pueden ser cuantificados mediante la concentración de ácidos grasos no esterificados (AGNE). Los períodos de balance energético negativo están caracterizados por la movilización grasa que se refleja en un aumento de la concentración circulante de AGNE (Chilliard y col., 1998; Ingvartsen y Andersen, 2000; Burke y Roche, 2007), generalmente acompañada con un incremento en la producción de cuerpos cetónicos. Por lo tanto, la concentración de los AGNE puede ser utilizada como un indicador de grados moderados de subnutrición, y expresa el equilibrio entre lipólisis y lipogénesis (Russel y col., 1967).

El presente trabajo se desarrolló con la finalidad de evaluar el efecto de dos planos nutricionales (alto y bajo) de alimentación materna durante la gestación temprana sobre las concentraciones de $\mathrm{P}_{4}$, metabolitos y las hormonas metabólicas involucradas en el desarrollo embrionario durante la gestación temprana y su incidencia en la eficiencia reproductiva en el ovino. 


\section{III.2 OBJETIVOS}

a) Evaluar la relación entre las pérdidas gestacionales con los cambios en el estado corporal de las madres durante los estadios iniciales de la preñez en ovejas Merino.

b) Determinar el efecto del nivel nutricional materno sobre el desarrollo de los embriones mediante cultivo in vitro.

c) Evaluar las concentraciones séricas de $\mathrm{P}_{4}$, metabolitos y las hormonas metabólicas que favorecen el desarrollo embrionario temprano, ante cambios en la condición corporal materna durante la preñez temprana en ovinos.

\section{III.3 HIPÓTESIS}

a) Las pérdidas de gestación en ovinos se relacionan con cambios negativos en la condición corporal materna durante los estadios iniciales de la preñez.

b) La disminución de la condición corporal materna durante los estadios iniciales de la preñez afecta negativamente el desarrollo de los embriones.

c) Los cambios en la condición corporal materna alteran las concentraciones séricas de $\mathrm{P}_{4}$, metabolitos y las hormonas metabólicas que favorecen el desarrollo embrionario temprano incidiendo sobre los resultados de la preñez en ovinos. 


\section{III.4 MATERIALES Y MÉTODOS}

\section{III.4.1 Animales y lugar de trabajo}

El estudio se realizó durante la estación reproductiva (otoño-invierno), en las instalaciones del Laboratorio de Reproducción de Rumiantes Menores, ubicado en la Estación Experimental Agropecuaria de INTA Bariloche, provincia de Río Negro $\left(71^{\circ} 15^{\prime}\right.$ longitud oeste y $41^{\circ}$ latitud sur $)$.

El cuidado y el tratamiento de los animales experimentales se realizaron de acuerdo con las directrices emitidas por la National Academy of Science, Washington DC, EE. UU. (National Research Council, 2011) y aprobadas por el Comité de Principios Rectores Internacionales para la Investigación Biomédica de Animales de Laboratorio (Comité Institucional de Cuidado y Uso de Animales [CICUAL]) de la FCV-UNLP; Número de protocolo: 55-3-16T.

Se utilizaron ovejas adultas de raza Merino $(n=126)$ de una majada general, siendo asignadas en forma completamente aleatoria para conformar dos grupos experimentales con sus repeticiones correspondientes. La edad y el estado corporal se estimaron utilizando los mismos métodos que en el Experimento I.

\section{III.4.2 Tratamientos de alimentación}

Todos los grupos se mantuvieron en corrales que proporcionaron $2 \mathrm{~m}^{2}$ /animal durante un período de estudio de 70 días, que abarcó el tratamiento progestacional-servicio y la primera etapa de gestación (entre los días -32 $( \pm 1)$ al 35 respecto al servicio). Durante este período, los grupos experimentales restringidos (R1 n=32 y R2 n=32), recibieron un nivel nutricional del 50\% de los 
requerimientos de energía de mantenimiento para que las ovejas disminuyan su CC un medio punto $(-0,5)$. En los grupos experimentales suplementados $(\mathrm{S} 1 \mathrm{n}=30$ y $\mathrm{S} 2$ $\mathrm{n}=32$ ), el nivel nutricional recibido durante el mismo período fue del $150 \%$ de los requerimientos de energía de mantenimiento, para que las ovejas aumenten su CC un medio punto $(+0,5)$. Los niveles nutricionales fueron alcanzados con una dieta en base a pellet de alfalfa con un aporte de $13 \%$ de proteína bruta/KgMS y grano de maíz. El cambio de 0,5 puntos de $\mathrm{CC}(\Delta \mathrm{CC})$ durante el período en estudio se utilizó para clasificar a las ovejas en dos grupos experimentales ( $\Delta$ positivo, $\Delta$ negativo), descartando aquellos animales en los que no se produjo un cambio de $\mathrm{CC}$.

\section{III.4.3 Sincronización de estros e inseminación artificial}

La sincronización de estros se realizó mediante la colocación de esponjas intravaginales durante 14 días (acetato de medroxiprogesterona (MAP), 60 mg; Progespon, Syntex SA, Argentina). Al retiro de la esponja intravaginal, se administró gonadotropina coriónica equina (eCG, 200 UI, Novormon, Syntex SA, Argentina) por vía intramuscular. Las hembras detectadas en celo, utilizando un macho marcador con arnés, fueron inseminadas a celo detectado por vía cervical con semen fresco (100 millones de espermatozoides totales/dosis), según la técnica descripta por Gibbons y Cueto (2010). Las dosis de semen se obtuvieron utilizando un pool a partir de los eyaculados de tres carneros, con características seminales óptimas (motilidad masal superior a 4; escala subjetiva 0 , mínima; 5 , máxima). 


\section{III.4.4 Muestreos}

El PV y la CC se determinaron cada 15 días desde el inicio hasta la finalización del tratamiento de alimentación. La extracción de sangre, el diagnóstico de gestación y la estimación de las pérdidas embrionarias y fetales entre el día 17 post servicio y el parto se realizaron como se describió en el Experimento I. Las pérdidas embrionarias tempranas (anteriores al día 17 post servicio) se calcularon mediante la diferencia entre la tasa de fertilidad obtenida luego de la recuperación de embriones en una submuestra de animales (Punto III.4.5) y el diagnóstico de preñez utilizando las concentraciones de $\mathrm{P}_{4}$ al día 17 (Fernández Abella y Formoso, 2007).

\section{III.4.5 Tasa de fertilización y desarrollo embrionario}

Para estudiar la tasa de fertilización en una subpoblación de ovejas de cada grupo experimental, se tomaron al azar 10 ovejas del grupo experimental $\mathrm{S}$ con $\Delta$ $\mathrm{CC}$ positivo ( $\Delta$ positivo) y 8 ovejas del grupo experimental $\mathrm{R}$ con $\Delta \mathrm{CC}$ negativo ( $\Delta$ negativo).

A los 6 días post detección de estros, se realizó una laparotomía para recolectar los ovocitos y embriones mediante el lavado desde el cuerno uterino al oviducto (Gibbons y Cueto, 2010). Brevemente, la recuperación quirúrgica embrionaria consistió en la colocación de una sonda (K33) que en su extremo dispone de una aguja (50/20) con punta no traumática y dos perforaciones laterales y una central. Se realizó una punción en la unión útero tubárica y se enhebró la sonda en el interior de la luz del cuerno uterino $(1 \mathrm{~cm})$, fijando la misma por medio de un clamp vascular o ligadura. Aproximadamente a un par de $\mathrm{cm}$ de la bifurcación 
de los cuernos uterinos, se realizó una segunda punción, para la inyección de $20 \mathrm{ml}$ de PBS a $38^{\circ} \mathrm{C}$. De esta manera se produjo una corriente de arrastre hacia la unión útero tubárica, donde estaba ubicada la sonda, y el medio de colecta fue recuperado en un Erlenmeyer estéril previamente entibiado. Se procedió de igual manera con el otro cuerno uterino. En el mismo momento, se observaron en cada una de las ovejas la cantidad de cuerpos lúteos presentes (Oldham y Lindsay, 1980). Finalizada la recuperación embrionaria, se realizó la sutura de los planos quirúrgicos y se administraron antibióticos.

El líquido recuperado del lavado de los cuernos uterinos por oveja donante fue examinado bajo lupa estereoscópica con platina térmica atemperada a $35^{\circ} \mathrm{C}$, para el recuento de ovocitos y embriones. Los embriones recolectados se evaluaron morfológicamente en sus aspectos de calidad y desarrollo (IETS, 1998).

Se calcularon las tasas de recuperación embrionaria (número de embriones + ovocitos recuperados / número de cuerpos lúteos por 100) y las tasas de fertilización (número de embriones recuperados / número de embriones + ovocitos recuperados por 100) según los tratamientos de alimentación.

Luego de su evaluación morfológica los embriones fueron colocados en estufa de cultivo, a $37^{\circ} \mathrm{C}$ en una atmosfera con $5 \% \mathrm{CO} 2$, identificados según el grupo experimental del $\Delta \mathrm{CC}$. Los mismos se colocaron en placas con $15 \mathrm{ml}$ de Eagle's minimum essential medium (MEM), suplementado con $2 \%$ de penicilina y estreptomicina. Se evaluó el desarrollo embrionario mediante la tasa de eclosión de blastocistos para cada tratamiento. 


\section{III.4.6 Análisis hormonales}

Las determinaciones de las concentraciones séricas de metabolitos (AGNE), de hormonas esteroideas $\left(\mathrm{P}_{4}\right)$ y de hormonas metabólicas (GH, insulina, IGF-1) se realizaron de acuerdo con el protocolo descripto en el Experimento I.

\section{III.4.7 Análisis estadístico}

Basado en un diseño experimental en bloques completamente aleatorizados, se realizaron los análisis estadísticos correspondientes para las variables consideradas. Las concentraciones de $\mathrm{P}_{4}$, hormonas metabólicas y metabolitos, fueron analizados con los mismos modelos matemáticos utilizados en el Experimento I, con el agregado del efecto de dieta como variable independiente. La tasa de fertilización, preñez y pérdidas embrionarias se analizaron utilizando el procedimiento CATMOD (SAS, 2003). Las medias de los tratamientos se compararon por Test de Tukey. Se consideraron diferencias estadísticamente significativas cuando el $\mathrm{P}$ valor fue $\mathrm{P}<0,05$ y se consideró una tendencia a la significancia cuando fue de $\mathrm{P}<0,1$. 


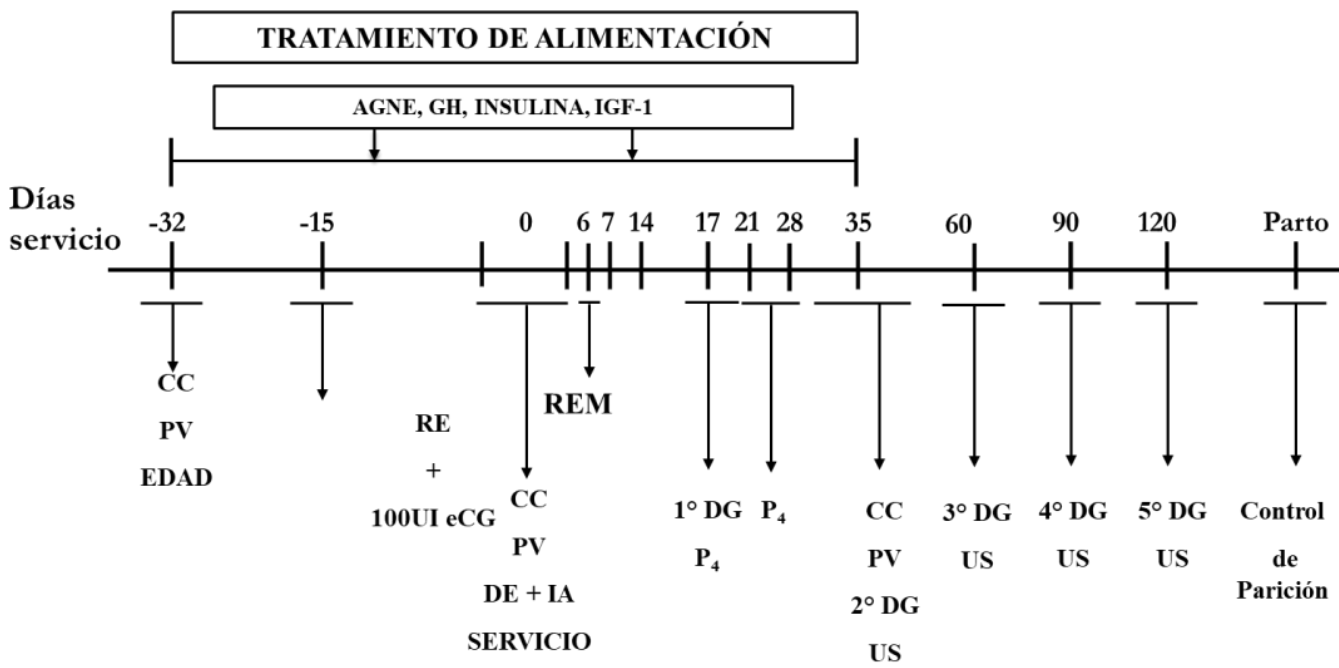

Figura III.1. Cronograma de actividades para evaluar la relación entre las pérdidas de gestación con los cambios en la condición corporal materna en ovejas Merino. CE: colocación de esponjas intravaginales; eCG, gonadotrofina coriónica equina; $\mathrm{RE}$, retiro de esponjas; CC: condición corporal; PV: peso vivo; DE: detección de celos; IA: inseminación artificial; IGF-1, factor de crecimiento similar a la insulina tipo $1 ; \mathrm{P}_{4}$, progesterona; $\mathrm{DG}$, diagnóstico de gestación; US, ultrasonografía; AGNE, ácidos grasos no esterificados; REM, recuperación embrionaria.

\section{III.5 RESULTADOS}

\section{III.5.1 Tratamientos de alimentación y estado corporal materno}

A excepción de los animales que no experimentaron cambios en su CC $(n=5)$ y fueron descartados del experimento, los restantes animales en estudio manifestaron un cambio en la CC entre los -32 y los 35 días respecto al servicio. Las ovejas del grupo $\mathrm{S}(\mathrm{n}=58)$ presentaron un cambio de $\Delta$ positivo de 0,6 puntos de ganancia de $\mathrm{CC}$, entre un valor inicial de $2,25 \pm 0,04$ puntos y un valor final de $2,85 \pm 0,05$ puntos; en tanto que las ovejas del grupo $R(n=63)$ presentaron un cambio $\Delta$ negativo de 0,4 puntos de pérdida de CC entre un valor inicial de 2,23 \pm 0,04 y un valor final de $1,80 \pm 0,06$ puntos. Por su parte, el PV en el grupo $\mathrm{S}$ aumentó $6,68 \mathrm{~kg}$ con un peso inicial de 38,95 $\pm 0,62 \mathrm{~kg}$ y un final de 45,63 $\pm 095 \mathrm{~kg}$; 
en animales del grupo $\mathrm{R}$ disminuyó $4,27 \mathrm{~kg}$ siendo el peso inicial $39,69 \pm 0,66 \mathrm{~kg}$ y el final $35,42 \pm 0,89 \mathrm{~kg}$.

Se observó que el grupo R evidenció una disminución significativa de PV y $\mathrm{CC}$ respecto al grupo $\mathrm{S}$ desde 32 días pre servicio hasta 35 días post servicio (Figura III.2., $\mathrm{P}<0,0001)$.
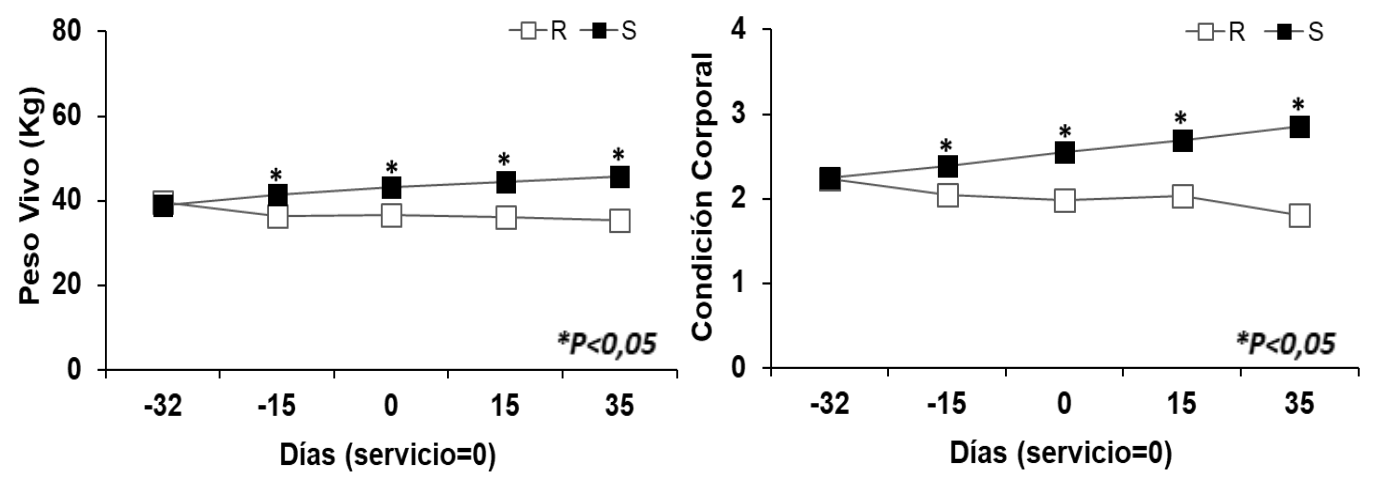

Figura III.2. Peso vivo y condición corporal desde 32 días pre-servicio hasta 35 días post servicio en hembras ovinas según el estado nutricional (Restringidas [R], $\mathrm{n}=63$; Suplementadas [S], $\mathrm{n}=58$ ). ${ }^{*} \mathrm{P}<0,05$.

\section{5.2 Presentación de estros}

La manifestación de estros se vio afectada por el cambio de PV y CC, ya que se observó que sólo 65,1\% (41/63) de las ovejas del grupo R presentaron estros mientras que en el grupo $\mathrm{S}$ este valor fue del 98,3\% (57/58) $(\mathrm{P}<0,0001)$.

Independientemente de los tratamientos de alimentación, el PV y la CC al momento de la detección de estros fueron menores en las ovejas que no manifestaron estros con respecto a las que sí los presentaron (Tabla III.1) $(\mathrm{P}<0,0001)$. 
Tabla III.1. Peso vivo y condición corporal al servicio entre hembras que manifestaron estros y hembras que no manifestaron estros.

\begin{tabular}{ccc}
\hline & $\begin{array}{c}\text { Hembras } \\
\text { sin estro }(\mathrm{n}=23)\end{array}$ & $\begin{array}{c}\text { Hembras } \\
\text { con estro }(\mathrm{n}=98)\end{array}$ \\
\hline Peso Vivo $(\mathrm{Kg})$ & $34,2 \pm 1,29^{\mathrm{a}}$ & $41,0 \pm 0,62^{\mathrm{b}}$ \\
Condición Corporal & $1,78 \pm 0,07^{\mathrm{a}}$ & $2,37 \pm 0,04^{\mathrm{b}}$ \\
\hline
\end{tabular}

Superíndices en una misma fila indican diferencias significativas $(\mathrm{P}<0,05)$.

A su vez, al considerar los animales que no manifestaron estro $(n=23)$, se observó que sufrieron una pérdida de PV promedio de 3,5 $\mathrm{Kg}$ y de 0,3 puntos de CC desde el inicio del tratamiento de alimentación hasta el momento de la detección de estros. Por otra parte, en todas las hembras que no manifestaron el estro se realizó una laparoscopía exploratoria para observar actividad ovárica. Se determinó que el $61 \%$ de las hembras tenía un cuerpo lúteo, indicando la ciclicidad durante el ciclo estral considerado, pero sin manifestación de celo (celo silente). El 39\% restante no presentó folículos ni cuerpos lúteos, evaluándose a estas hembras en fase de anestro. Asimismo, se observó que las ovejas con celo silente presentaron una CC mayor $(1,98 \pm 0,07)$ respecto a las ovejas que se encontraban en anestro $(1,50 \pm 0,09)$ $(\mathrm{P}<0,05)$.

\section{III.5.3 Tasa de fertilidad y desarrollo embrionario}

En los subgrupos analizados por tratamiento de alimentación $(S, n=10 ; R$, n=8), el número de cuerpos lúteos promedio por oveja no difirió entre tratamientos y fue de $1,3 \pm 0,03$ en el grupo $\mathrm{S}$ y de $1,1 \pm 0,04$ en el grupo $\mathrm{R}(\mathrm{P}>0,05)$. La tasa de recuperación embrionaria fue de $66,7 \%$ en ovejas restringidas y de $46,2 \%$ en ovejas suplementadas, sin alcanzar significancia estadística la diferencia $(\mathrm{P}>0,05)$. 
Las tasas de fertilidad obtenidas luego de la recuperación de embriones no difirieron entre las hembras del grupo $\mathrm{S}(83,3 \%)$ respecto a las hembras del grupo $\mathrm{R}(100 \%)$, respectivamente $(\mathrm{P}>0,05)$.

El $100 \%$ de los embriones provenientes de las madres del grupo $\mathrm{S}$ evolucionaron de mórula compacta a blastocisto, evidenciando una calidad embrionaria Grado 2. En cambio, los embriones provenientes de madres restringidas presentaron una tasa de evolución del 83,3\% y en el $60 \%$ de ellos presentó una calidad embrionaria menor (Grado 3).

\section{III.5.4 Diagnóstico de gestación y pérdidas gestacionales}

Según la metodología propuesta (Punto III.4.4), las pérdidas embrionarias tempranas se calcularon mediante la diferencia entre la tasa de fertilidad obtenida luego de la recuperación de embriones (83,3 y 100\% para los grupos S y R, respectivamente, obtenida en el punto III.5.2 en una submuestra de animales) y el diagnóstico de preñez utilizando las concentraciones de $\mathrm{P}_{4}$ al día 17: 85,1 (40/47) y $87,9 \%$ (29/33) para los grupos $\mathrm{S}$ y $\mathrm{R}$ que no presento diferencias significativas, respectivamente $(\mathrm{P}>0,05)$. A partir de estos valores, se obtuvieron tasas de pérdidas gestacionales tempranas del $0 \%$ en las hembras suplementadas y del $12,1 \%$ en las hembras restringidas.

Las tasas de preñez al día 35 post servicio, diagnosticadas mediante ecografía, no difirieron entre los grupos de tratamiento, siendo del 78,7 (37/47) y del 81,8\% (27/33) en los grupos $\mathrm{S}$ y $\mathrm{R}$, respectivamente $(\mathrm{P}=0,21)$. 
Mediante la diferencia en los diagnósticos de gestación entre los días 17 y 35 post servicio, se detectaron un $6,4(3 / 47)$ y un $6,1(2 / 33) \%$ de pérdidas embrionarias tardías en las ovejas de los grupos $\mathrm{S}$ y $\mathrm{R}$, respectivamente $(\mathrm{P}=0,29)$.

No se presentaron pérdidas fetales desde el día 35 post servicio hasta el parto, por lo que las pérdidas embrionarias totales fueron del $6,4 \%$ para el grupo $\mathrm{S}$, ocurridas entre los días 17 y 35 post servicio, y del 18,2\% para el grupo R, ocurridas entre la fertilización y el día 35 post servicio $(\mathrm{P}=0,18)$.

Debido a la gran proporción de ovejas restringidas que no manifestó celo, se calculó la tasa de Eficiencia Global para cada tratamiento de alimentación (tasa de presentación de estro x tasa de preñez al día 35 / 100), obteniéndose valores del 77,4 y $53,3 \%$ para los grupos $\mathrm{S}$ y $\mathrm{R}$, respectivamente $(\mathrm{P}<0,05)$.

\section{III.5.5 Concentraciones de $\mathrm{P}_{4}$}

Las concentraciones de $\mathrm{P}_{4}$ se evaluaron considerando los diagnósticos de gestación en los días 17 y 35, por lo cual las ovejas se agruparon en no preñadas (por fallas en la fertilización y por pérdidas embrionarias tempranas), ovejas preñadas sin pérdidas $\mathrm{y}$ ovejas preñadas con pérdidas embrionarias, independientemente de los tratamientos de alimentación.

Se evidenció que la concentración de $\mathrm{P}_{4}$ en los días 17 y 21 post servicio fue mayor en las ovejas preñadas vs. las ovejas no preñadas $(\mathrm{P}<0,0001)$; pero esta diferencia no se mantuvo en el día 28 post servicio ( $\mathrm{P}=0,97$; Tabla III.2).

Las ovejas que sufrieron pérdidas embrionarias entre el día 17 y 35 post servicio, evidenciaron una alta concentración de $\mathrm{P}_{4}$ al día 17 , que no se diferenció de las ovejas preñadas, pero luego al día 21 se observó una disminución de las 
concentraciones de $\mathrm{P}_{4}$ alcanzando un promedio similar a las ovejas no preñadas (Tabla III.2). En este estudio se detectó la presencia de una sola oveja no cíclica.

Tabla III.2. Concentración sérica (MMC \pm ES) de $\mathrm{P}_{4}$ en los días 17, 21 y 28 post servicio en ovejas no preñadas al día 17 post servicio y ovejas preñadas con y sin pérdidas embrionarias al día 35 (DG 35) de gestación.

\begin{tabular}{cccc}
\hline \multicolumn{3}{c}{ Progesterona (ng/ml) DG35 } \\
\hline $\begin{array}{c}\text { No preñadas } \\
(\mathrm{n}=11)\end{array}$ & $\begin{array}{c}\text { Preñadas } \\
\text { sin pérdidas } \\
\text { embrionarias } \\
(\mathrm{n}=64)\end{array}$ & $\begin{array}{c}\text { Preñadas } \\
\text { con pérdidas } \\
\text { embrionarias } \\
(\mathrm{n}=5)\end{array}$ \\
\hline 17 & $0,42 \pm 0,70^{\mathrm{a}}$ & $6,92 \pm 0,45^{\mathrm{b}}$ & $8,26 \pm 1,58^{\mathrm{b}}$ \\
21 & $1,40 \pm 1,02^{\mathrm{a}}$ & $5,76 \pm 0,43^{\mathrm{b}}$ & $1,02 \pm 1,52^{\mathrm{a}}$ \\
28 & $5,82 \pm 1,18^{\mathrm{a}}$ & $5,95 \pm 0,50^{\mathrm{a}}$ & $6,26 \pm 1,74^{\mathrm{a}}$ \\
\hline
\end{tabular}

Superíndices en la misma fila indican diferencias significativas $(\mathrm{P}<0,05)$.

DG: diagnóstico de gestación.

Los cambios en la $\mathrm{CC}$ no tuvieron un efecto significativo sobre las concentraciones de $\mathrm{P}_{4}$, (grupo $\mathrm{S}, 5,30 \pm 0,34 \mathrm{ng} / \mathrm{ml}$ y grupo $\mathrm{R}, 6,08 \pm 0,40 \mathrm{ng} / \mathrm{ml}$, $\mathrm{P}>0,05)$.

\section{III.5.6 Metabolitos y hormonas metabólicas}

El efecto del cambio en la $\mathrm{CC}$ se vio reflejado en las concentraciones de AGNE, ya que en el grupo de ovejas $\mathrm{R}(1140,6 \pm 53,9 \mu \mathrm{M} / \mathrm{L})$ se observaron mayores concentraciones que en el grupo $\mathrm{S}(236,7 \pm 47,3 \mu \mathrm{M} / \mathrm{L})$ desde el día -32 pre-servicio al 35 post servicio $(\mathrm{P}<0,05)$.

Sin embargo, las concentraciones de AGNE no fueron significativamente diferentes entre ovejas preñadas y no preñadas al día 35 post servicio, aunque se observó una tendencia a presentar concentraciones más elevadas en ovejas preñadas 
$(729,2 \pm 73,7 \mu \mathrm{M} / \mathrm{L})$ en comparación con ovejas no preñadas $(549,2 \pm 66,2 \mu \mathrm{M} / \mathrm{L})$ $(\mathrm{P}=0,07$, Figura III.3).

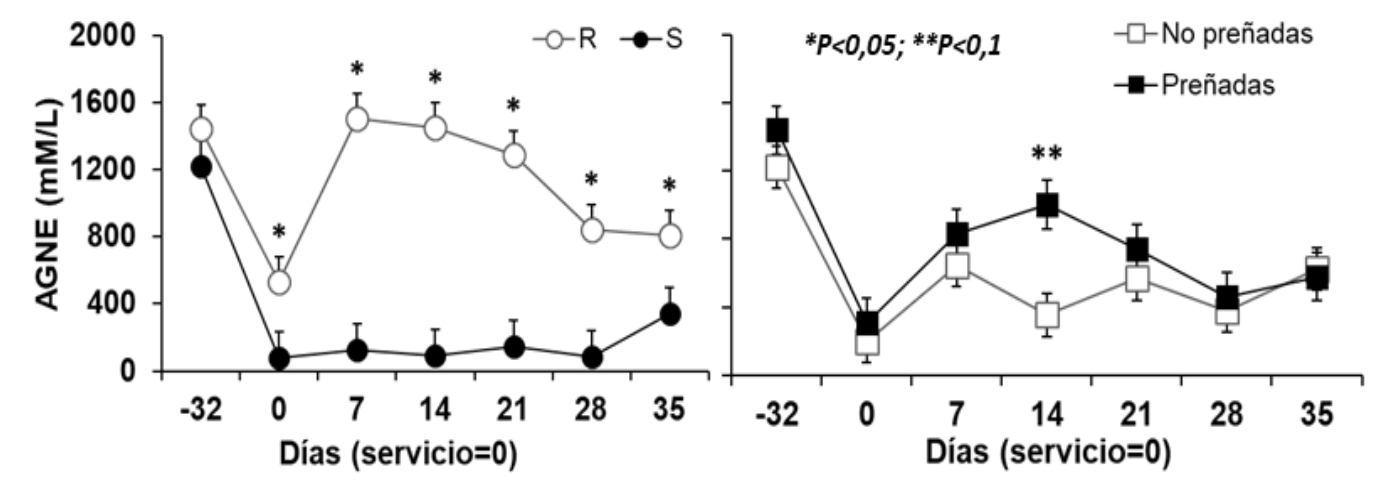

Figura III.3. Concentración sérica de ácidos grasos no esterificados (AGNE; $\mathrm{MMC} \pm \mathrm{ES}$ ), en relación al tratamiento nutricional (Restringido, [R], $\mathrm{n}=15$ y Suplementado [S], $\mathrm{n}=17$, panel izquierdo) y el diagnóstico de gestación (no preñadas, $n=16$, preñadas, $n=16$; panel derecho) en ovejas Merino incluido los días -32 y 35 del servicio ${ }^{*} \mathrm{P}<0,05$; $* \mathrm{P}<0,1$.

Las concentraciones de GH fueron más elevadas en las ovejas que disminuyeron su $\mathrm{CC}$ en comparación con aquellas ovejas que ganaron $\mathrm{CC}$ desde el momento del servicio hasta el día 35 post servicio $(\mathrm{P}<0,0001$; Figura III.4).

A su vez, las hembras diagnosticadas como no preñadas al día 35 presentaron una tendencia a mayores concentraciones de $\mathrm{GH}$ que las ovejas preñadas ( $\mathrm{P}=0,05$; Figura III.4). En ovejas que perdieron la gestación se observó una tendencia a mayores concentraciones promedios de $\mathrm{GH}(2,76 \pm 0,38 \mathrm{ng} / \mathrm{ml})$; en comparación con ovejas no preñadas $(2,28 \pm 0,23 \mathrm{ng} / \mathrm{ml})$ y preñadas $(1,88 \pm 0,18$ $\mathrm{ng} / \mathrm{ml}, \mathrm{P}=0,08)$. 

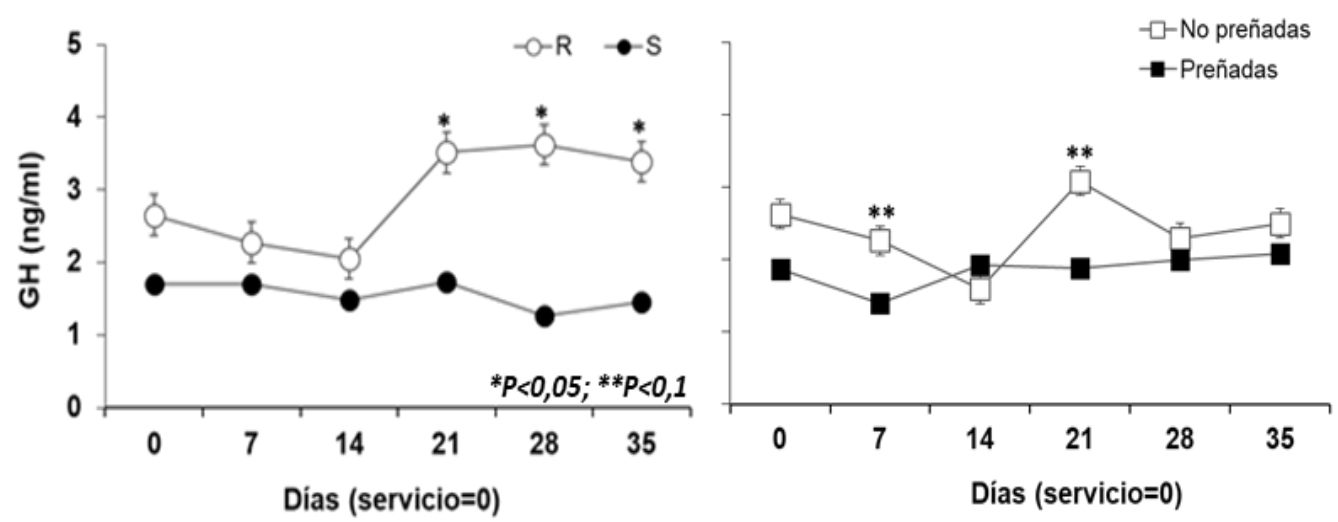

Figura III.4. Concentración sérica de la hormona de crecimiento (GH; $\mathrm{MMC} \pm \mathrm{ES}$ ), en relación con el tratamiento nutricional (Restringido [R], $\mathrm{n}=15$; Suplementado [S], $\mathrm{n}=17$; panel izquierdo) y el diagnóstico de gestación (no preñadas, $\mathrm{n}=16$; preñadas, $\mathrm{n}=16$; panel derecho) en ovejas Merino entre los días 0 y 35 del servicio $* \mathrm{P}<0,05$; $* \mathrm{P}<0,1$.

Las concentraciones séricas de insulina e IGF-1 fueron influenciadas significativamente por el cambio en la CC, observándose mayores concentraciones en las ovejas del grupo $\mathrm{S}$ en comparación con el grupo de ovejas $\mathrm{R}(\mathrm{P}<0,05$; Figura III.5).

No se observó efecto de la preñez diagnosticada al día 35 post servicio sobre las concentraciones de insulina e IGF-1 durante todo el período de estudio (Figura III.5). Asimismo, las ovejas que presentaron pérdidas gestacionales no evidenciaron cambios en las concentraciones de insulina e IGF-1, respecto a las ovejas que mantuvieron la gestación $(\mathrm{P}>0,05)$. 

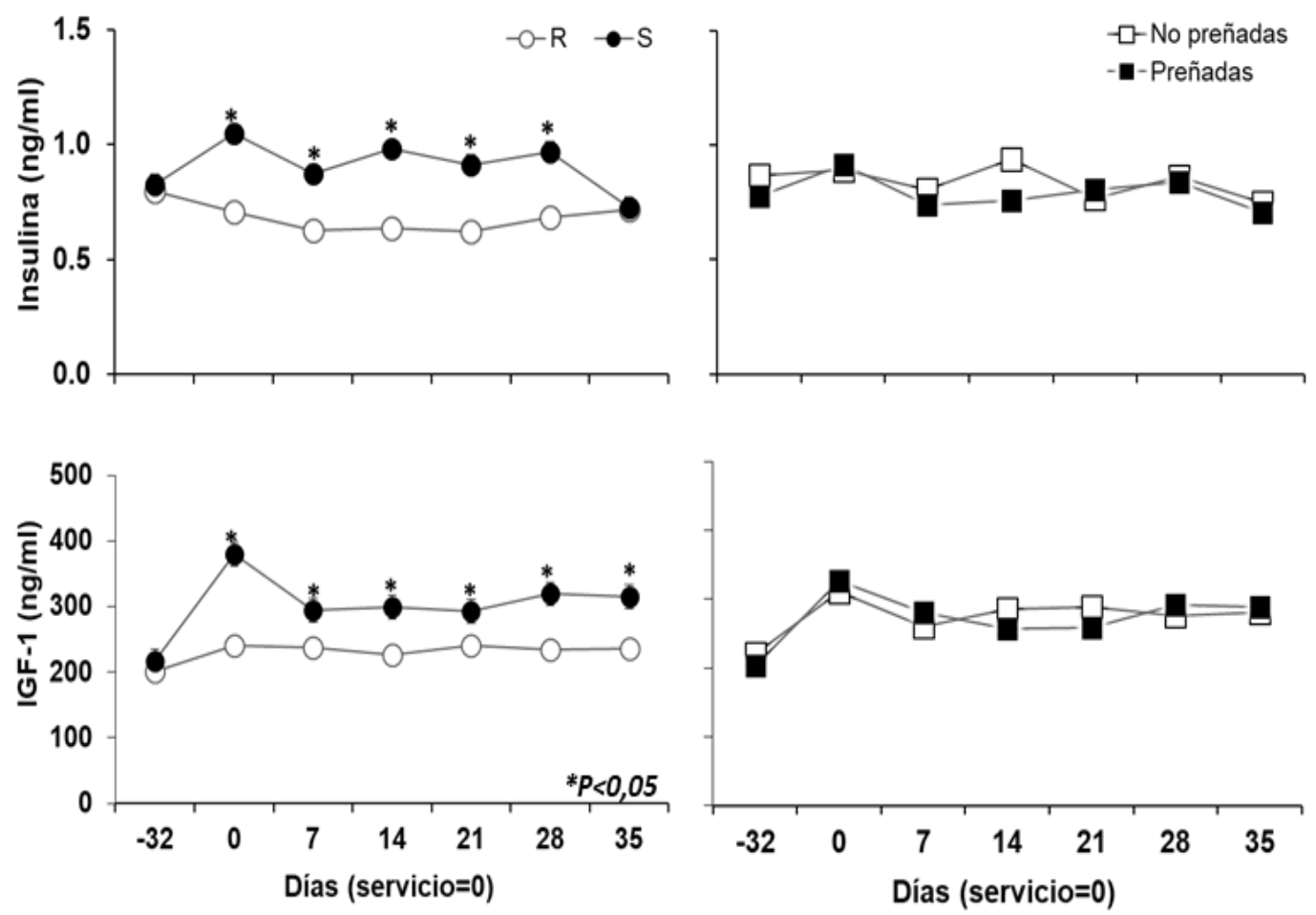

Figura III.5. Concentraciones séricas de insulina y factor de crecimiento similar a la insulina tipo 1 (IGF-1; MMC $\pm \mathrm{ES}$ ), en relación con el tratamiento nutricional (Restringido [R], $\mathrm{n}=15$; Suplementado [S], $\mathrm{n}=17$; panel izquierdo) y el diagnóstico de gestación (no preñadas, $\mathrm{n}=16$; preñadas, $n=16$; panel derecho) en ovejas Merino entre los días -32 y 35 del servicio.

\section{III.6 DISCUSIÓN}

\section{Influencia de la CC en la presentación de estros}

En el presente ensayo experimental se corroboró que la pérdida de 0,4 puntos de CC durante el preservicio en temporada reproductiva, afectó negativamente la manifestación del estro en hembras ovinas. Este resultado acompaña lo descripto anteriormente en el Experimento I donde si bien no hubo descenso de CC previo al servicio, las ovejas sin manifestación de estro presentaron menor CC que las ovejas que presentaron celo.

Tal como se mencionó en el Experimento I, en ovinos, varios estudios han relacionado la $\mathrm{CC}$ con el desempeño reproductivo, específicamente la baja $\mathrm{CC}$ se 
ha asociado con un retraso o la supresión del estro (Gunn y Doney, 1975), disminución de la foliculogénesis (Rhind y col., 1989a) y alteración en la tasa ovulatoria (Viñoles y col., 2002; de la Isla Herrera y col., 2010).

Sin embargo, en este capítulo pudimos corroborar la incidencia de la disminución de la CC previo al servicio sobre la presentación de celos silentes post sincronización de estros, debido a la presencia de cuerpos lúteos en el $61 \%$ de las ovejas que no manifestaron celo. La presentación de celos silentes ante la carencia de nutrientes en la temporada reproductiva ha sido descripta por otros autores (Gunn y Doney, 1975; Forcada y col., 1992; Rondon y col., 1996), pero se desconoce el mecanismo específico que lleva a su ocurrencia. En este sentido, se ha descripto en ovinos que la subnutrición durante el período peri-concepcional, produce alteraciones en las concentraciones séricas de metabolitos, como la disminución de glucosa en sangre (Rumball y col., 2008; Ashworth y col., 2009), promoviendo una menor actividad folicular que altera el comportamiento del estro (Dupont y col., 2014).

\section{Cambios de CC, tasa de preñez y pérdidas gestacionales}

Las pérdidas embrionarias tempranas, calculadas como la diferencia entre el diagnóstico de gestación al día 17 post servicio y la tasa de fertilización al día 6 post servicio, no difirieron entre grupos de tratamiento y fueron de baja magnitud. A su vez, las pérdidas embrionarias tardías, calculadas como la diferencia entre los diagnósticos de preñez a los días 35 y 17 post servicio, tampoco fueron diferentes entre grupos, siendo también de baja magnitud; asimismo no se registraron pérdidas fetales hasta el parto. Durante este estudio, las ovejas de los grupos S y R 
evidenciaron una diferencia de más de $10 \mathrm{~kg}$ y más de un punto en la $\mathrm{CC}$ entre sí, sin embargo, no se encontraron diferencias en las tasas de preñez entre ambos grupos. Estos resultados demuestran que aun aumentando la variación en el rango de $\mathrm{CC}$, no fue posible encontrar un efecto de la restricción nutricional sobre las pérdidas gestacionales.

Más aún, a pesar de que las ovejas restringidas fueron sometidas a una pérdida de $\mathrm{CC}$ de 0,4 puntos en un período de 67 días en torno al servicio, evidenciando una $\mathrm{CC}$ de 1,8 a los 35 días post servicio, las mismas presentaron pérdidas gestacionales de poca magnitud, destacando su buen desempeño reproductivo y adaptación a las condiciones de cría patagónicas.

Sin embargo, es de destacar la gran proporción de hembras de baja CC que presentó anestro o celos silentes, lo cual resalta una particularidad intrínseca de la especie que, previendo las deficiencias energéticas imperantes, evitaría una preñez que no puede llevar a cabo. En virtud de la menor presentación de estros en el grupo $\mathrm{R}$, es importante resaltar la menor eficiencia global de este grupo en comparación con el grupo S $(53,3$ y $77,4 \%$ de eficiencia global para las ovejas subnutridas y suplementadas, respectivamente) lo cual perjudicaría el desempeño reproductivo de las majadas que presentan ovejas restringidas nutricionalmente al momento del servicio.

Distintos autores han utilizado diferentes métodos para cuantificar las pérdidas embrionarias tempranas antes del día 17 post servicio. Los métodos utilizados se basan fundamentalmente en la valoración de las pérdidas embrionarias a través de la relación entre el recuento de cuerpos lúteos y la cantidad de embriones 
recuperados, o mediante la evaluación de la presencia o no de embriones post servicio mediante la colecta embrionaria del tracto reproductivo.

El primer método, reportado en la bibliografía por distintos autores (Gunn y col., 1972; Gunn y Doney, 1975, 1979; Rhind y col., 1984), resulta de escaso valor ya que no permite discriminar entre las fallas en la fertilización y las pérdidas embrionarias tempranas.

El segundo método mencionado fue el elegido por nosotros, al permitir estimar una tasa de fertilización mediante la recuperación embrionaria $y$, por consiguiente, permitir realizar una mejor estimación de las pérdidas embrionarias tempranas. Utilizando el mismo método y día de colecta embrionaria que en nuestro estudio, Fernández Abella y Formoso (2007) encontraron mayores pérdidas (22\%) a las descriptas por nosotros con influencia del estado corporal materno.

Otros autores que han evaluado la mortalidad embrionaria por presencia o ausencia del embrión mediante la colecta embrionaria del tracto reproductivo describieron una pérdida de hasta el 50\% de embriones entre el día 7 y el día 15 post servicio en ovejas subnutridas (Lozano y col., 1998a). Abecia y col. (1995, 1997, 1999). Además, no encontraron diferencias en la presencia de embriones entre ovejas subnutridas y controles a los días 8 y 9 post servicio, pero sí encontraron menor número de embriones en ovejas subnutridas en los días 14 y 15 de gestación. En este mismo sentido, la gran mayoría de los estudios informan que la mortalidad embrionaria aumenta con la disminución de la CC (Gunn y col., 1972; Gunn y Doney, 1975; Abdel-Mageed, 2009). Sin embargo, y en coincidencia con nuestros resultados, un menor número de trabajos reporta que no se evidenciaron 
efectos del estado corporal sobre la mortalidad embrionaria (Cumming y col., 1975; Rhind y col., 1984).

Es necesario mencionar que posteriormente a la realización de nuestros estudios se ha avanzado en el desarrollado un método para el diagnóstico temprano de la preñez al día 18 mediante la evaluación de la irrigación del CL con la técnica de ultrasonografía Doppler color (Arashiro y col., 2018; Cosentino y col., 2019). A su vez, Kose y col. (2016) han propuesto la detección de la mortalidad embrionaria mediante la evaluación de la expresión de genes estimulados por interferón tau en sangre periférica de los leucocitos, lo cual serviría para anticipar la detección de las pérdidas embrionarias tempranas que ocurren próximas al proceso de implantación.

Al considerar las tasas de preñez logradas a los días 17 y 35 post servicio, no se evidenciaron diferencias entre tratamientos de alimentación. En coincidencia con nuestros resultados, otros investigadores trabajando con la raza Aragonesa con condiciones nutricionales comparables, no encontraron diferencias en la tasa de preñez al día 40 en ovejas receptoras de embriones (de Brun y col., 2016). Asimismo, Newton y col. (1980) describieron que la tasa de preñez tiene una relación negativa tanto en ovejas con baja CC $(2,0)$ como en ovejas con alta CC $(4,0)$. Sin embargo, otros estudios en las razas Manchega (Molina y col., 1994), Merino (Kleemann y Walker, 2005b) y Cheviot (Gunn y col., 1991) señalan una relación positiva entre la $\mathrm{CC}$ y la tasa de preñez. Estos resultados aparentemente contradictorios podrían explicarse por los distintos entornos endocrinos causados por los cambios nutricionales, que no fueron investigados en los trabajos 
mencionados, además de por la sensibilidad diferencial inherente a las distintas razas utilizadas.

\section{Relación entre el estado corporal, la tasa de fertilidad y el desarrollo}

\section{embrionario temprano}

En nuestro trabajo, no encontramos diferencias en las tasas de ovulación entre ovejas suplementadas y restringidas, encontrándose resultados contrastantes en la bibliografía. En algunos trabajos se ha encontrado una menor tasa de ovulación en ovejas con baja CC o subnutridas (Mc Neilly y col., 1987; Rhind y col., 1989a) mientras que, en otros estudios similares al nuestro, pero en diferentes razas (Lozano y col., 2003; Peura y col., 2003; Kakar y col., 2005), no se han encontrado diferencias en este parámetro. Asimismo, se sugiere que el umbral de aumento que puede alcanzarse en la tasa de ovulación según la alimentación depende de la raza y que la relación entre el peso vivo y la tasa de ovulación no es lineal sino curvilínea, de modo que, por cada $\mathrm{kg}$ adicional de peso vivo, la ganancia relativa en la tasa de ovulación disminuye (Smith, 1991).

La tasa de recuperación embrionaria no alcanzó a ser significativamente más alta en las ovejas restringidas que en las suplementadas, quizás debido al bajo número de embriones recuperados en ovejas ovuladas naturalmente. Abecia y col. (2015), utilizando ovejas superovuladas, obtuvieron una menor tasa de recuperación al día 7 post celo en ovejas subnutridas con respecto a las hembras controles, pero Lozano y col. (2003), al día 4 post retiro de esponjas, no observaron diferencias en la tasa de recuperación embrionaria entre ovejas superovuladas alimentadas ad libitum, controles y subnutridas. 
La tasa de fertilización en este estudio no se vio afectada por el estado de restricción nutricional, aunque ha sido reportado que los ovocitos obtenidos de animales subnutridos presentan una menor tasa de fertilización que los obtenidos de ovejas con dietas de mantenimiento (O'Callaghan y col., 2000; Lozano y col., 2003).

En este estudio se evidenció que todos los embriones de ovejas suplementadas desarrollaron en blastocistos de grado II, en tanto que un $83 \%$ de los embriones de ovejas restringidas desarrollaron hasta blastocistos y el $60 \%$ de ellos presentó una calidad embrionaria de grado III. Algunos autores han descripto que la subnutrición aumenta la mortalidad embrionaria debido a que la calidad y el desarrollo de los embriones se ve perjudicado por la falta de nutrientes (Lozano y col., 2003; Abecia y col., 2006; Ashworth y col., 2009). Borowczyk y col. (2006) informaron que la subnutrición de las ovejas donantes tiene un efecto negativo en la calidad de los ovocitos, lo que resulta, al igual que en nuestro estudio, en tasas más bajas de eclosión y formación de blastocistos.

En base a los resultados expuestos hasta aquí, es posible argumentar que pese al menor desarrollo y calidad morfológica de los embriones que se presentó en el grupo R, estos fueron capaces de llevar adelante una preñez viable, debido a que no se presentaron diferencias de preñez entre los grupos R y S.

\section{Respuesta endocrino-metabólica al tratamiento nutricional}

Las diferencias en las concentraciones de $\mathrm{P}_{4}$ entre ovejas preñadas y no preñadas permitieron realizar un correcto diagnóstico temprano de gestación al día 17 post servicio. A diferencia de lo observado en el experimento I, en el 
experimento II las concentraciones de $\mathrm{P}_{4}$ al día 28 post servicio no fueron diferentes entre ovejas con cuerpo lúteo gestacional y aquellas con cuerpo lúteo de la fase luteal, debido a que hubo una menor cantidad de ovejas que no ciclaron en la repetición del ciclo.

A su vez, se observa una elevada concentración de $\mathrm{P}_{4}$ al día 17 en ovejas que posteriormente pierden su gestación sin diferencias en cuanto al tratamiento nutricional aplicado. Según Brien y col. (1981), elevadas concentraciones de $\mathrm{P}_{4}$ en ovejas subnutridas se asocian con pérdidas embrionarias, debido a una disminución en la metabolización hepática de la hormona, aumentando las concentraciones plasmáticas.

En relación con los tratamientos nutricionales, no se encontraron diferencias en las concentraciones de $\mathrm{P}_{4}$ entre animales suplementados y restringidos, a pesar de haber incrementado la variación en la CC entre los grupos experimentales. Algunos autores han sugerido que, debido a la relación errática entre el nivel nutricional, las concentraciones séricas de $\mathrm{P}_{4}$ y la supervivencia embrionaria, la medición de $\mathrm{P}_{4}$ circulante no es suficiente como reflejo de su concentración en el tracto reproductivo, y que deberían medirse las concentraciones de la hormona a nivel local (Rhind y col., 1989c). Sumado a esto, las acciones de la hormona también dependen de la sensibilidad uterina (expresión de sus receptores e interacciones con otras hormonas y factores de crecimiento) (DeMayo y Lydon, 2019).

Como se ha descripto por otros autores (Sosa y col., 2009a; de Brun y col., 2016), en este estudio las ovejas con un consumo menor a sus requerimientos 
nutricionales presentaron un aumento en las concentraciones plasmáticas de AGNE debido al descenso de PV y CC, reflejando un incremento en la actividad lipolítica (Chillliard y col., 1998).

En cuanto a la relación entre la preñez y las concentraciones de AGNE, la mayoría de los investigadores no observaron diferencias en este metabolito al comparar ovejas subnutridas preñadas y no preñadas (de Brun y col., 2015; Abecia y col., 2015), o entre ovejas preñadas y no preñadas (de Brun y col., 2016). Sin embargo, en este estudio se presentó una tendencia a mayores concentraciones de AGNE en las ovejas preñadas en comparación con las no preñadas en las ovejas subnutridas. Esta diferencia en las concentraciones de AGNE entre ovejas subnutridas preñadas y no preñadas puede deberse a que los requerimientos nutricionales de una oveja preñada son mayores a los de una oveja no preñada aún en su primer mes de gestación.

En este estudio, se observó un incremento de la hormona de crecimiento (GH) y una disminución en las concentraciones de insulina e IGF-1 en ovejas sometidas a restricción nutricional. La GH estimula la producción de insulina e IGFs, mejorando el desarrollo del conceptus y aumentando la producción de $\mathrm{P}_{4}$ por la inducción de la transformación de células luteales chicas en grandes (Scaramuzi y col., 2006). La restricción nutricional provoca una disminución en la expresión hepática de los receptores de GH, lo que lleva al desacople del eje somatotrópico (Ketelslegers y col., 1995; Breier, 1999; Kim, 2014). Esto provoca, como se ha observado en nuestro estudio, un aumento de las concentraciones de GH y reducción en el IGF-1 circulante, en las ovejas subnutridas (Chilliard y col., 1998; Kobayashi y col., 1999). En ovejas que perdieron la gestación, se observó una 
tendencia a mayores concentraciones de $\mathrm{GH}$, alcanzándose concentraciones más altas que en las ovejas preñadas y no preñadas.

El incremento de insulina que se presentó en ovejas con un cambio de CC positivo reflejó el mejor estado energético, resultado que confirma los obtenidos por otros autores (Sosa y col., 2006; Fernández Foren y col., 2011). Sin embargo, a diferencia de nuestro estudio, estos mismos trabajos no han observado disminuciones importantes de IGF-1 tras la subnutrición, observándose diferencias sólo alrededor del estro (Sosa y col., 2006). En este sentido, se ha propuesto un efecto estimulador de la insulina sobre la sensibilidad hepática a $\mathrm{GH}$ y la consecuente síntesis de IGF-1 (Butler y col., 2003; Rhoads y col., 2004). En nuestro trabajo, a pesar de haber un aumento de estas hormonas en ovejas con mejor CC, esto no tuvo efecto sobre las tasas de preñez lograda coincidiendo en este aspecto con los mismos autores citados anteriormente.

En resumen, contrariamente a nuestra hipótesis inicial, el principal efecto de la restricción nutricional sobre la eficiencia reproductiva se evidenció sobre la cantidad de ovejas que manifestaron estro $(65 \%)$, encontrándose que las pérdidas gestaciones fueron de baja magnitud y no fueron influenciadas por el estado corporal materno en torno al período de servicio e implantación embrionaria. Estas observaciones permitirían explicar las menores tasas de preñez observadas a campo en ovejas que presentan una baja condición corporal, debido a que una proporción de ellas entraría en anestro o presentaría celos silentes ante una restricción nutricional, evitando así la ocurrencia de la preñez inmediata ante condiciones desfavorables. 
A su vez, se observó una influencia de los cambios en la CC sobre las concentraciones de AGNE, GH, insulina e IGF-1 entre las ovejas suplementadas y restringidas que, sin embargo, no se reflejaron en las pérdidas gestacionales tempranas, por lo tanto, no evidenciándose diferencias en las tasas de preñez entre los grupos R y S. 


\section{CAPITULO IV}

\section{EFECTO DEL ESTADO NUTRICIONAL MATERNO SOBRE LA \\ CALIDAD EMBRIONARIA Y EL AMBIENTE UTERINO DURANTE LA \\ PREÑEZ TEMPRANA}

\section{IV.1 INTRODUCCIÓN}

Los estudios que investigan la influencia de la subnutrición sobre el ambiente endocrino-metabólico materno y su relación con las fallas en el desarrollo embrionario son escasos en la especie ovina.

El modelo de ovejas superovuladas ha sido utilizado para evaluar el efecto de la subnutrición sobre la calidad de los ovocitos y embriones (Lozano y col., 2003; Abecia y col., 2015), así también como para estudiar los efectos de la subnutrición sobre la interrelación entre el ambiente materno y el embrión (de Brun y col., 2016). Asimismo, se ha descripto, que la expresión génica del oviducto y el útero puede encontrarse alterada en ovejas con subnutrición afectando el desarrollo embrionario temprano (Sosa y col., 2008; Sosa y col., 2009b; de Brun y col., 2013; Fernández Foren y col., 2019); sin embargo, se presentan pocos estudios al respecto en la bibliografía.

El desarrollo embrionario durante el período de pre-implantación es afectado por el nivel nutricional materno; debido a ello, las investigaciones se han enfocado en el estudio de los efectos de un balance energético negativo sobre el conjunto de hormonas y factores que influencian el ambiente materno, evaluando las concentraciones de AGNE, insulina, leptina, IGF-I, entre otros, utilizados como indicadores del estado metabólico (Kaye, 1997). 
El presente estudio fue diseñado para evaluar si las fallas reproductivas influidas por el tratamiento nutricional se ocasionan principalmente por efecto del embrión (oveja donante), el ambiente uterino (oveja receptora), o por ambos efectos. A su vez, se evaluó el efecto de los tratamientos nutricionales sobre las concentraciones de AGNE, insulina, IGF-1 y leptina y la expresión génica uterina de los receptores de $\mathrm{P}_{4}(\mathrm{PR})$, IGF-1 (IGF-1R) y leptina (LEPR) en ovejas donantes y receptoras de embriones.

\section{IV.2 OBJETIVOS}

Los objetivos de este capítulo fueron:

a) Evaluar el efecto del estado nutricional de hembras donantes y receptoras de embriones sobre la sobrevivencia embrionaria luego de la siembra directa de embriones ovinos.

b) Determinar el efecto del nivel nutricional de hembras donantes sobre el desarrollo de los embriones.

c) Determinar el efecto del estado nutricional materno sobre las concentraciones de AGNE, insulina, IGF-1 y leptina y la expresión génica uterina de donantes y receptoras de embriones.

\section{IV.3 HIPÓTESIS}

Las hipótesis de este capítulo fueron:

a) La sobrevivencia embrionaria post transferencia de embriones es influenciada por el ambiente uterino de las hembras donantes y receptoras de embriones. 
b) La subnutrición de las hembras donantes de embriones afecta el desarrollo embrionario.

c) El estado nutricional materno afecta las concentraciones de AGNE, insulina, IGF-1 y leptina y la expresión génica uterina de donantes y receptoras de embriones.

\section{IV.4 MATERIALES Y MÉTODOS}

\section{IV.4.1 Animales y lugar de trabajo}

El trabajo experimental se llevó a cabo en las instalaciones del Laboratorio de Reproducción de Rumiantes Menores del INTA Bariloche (71 15’ 12” longitud oeste y $41^{\circ} 07^{\prime} 23^{\prime \prime}$ latitud sur).

El cuidado y el tratamiento de los animales experimentales se realizaron de acuerdo con las directrices emitidas por la National Academy of Science, Washington DC, EE. UU. (National Research Council, 2011) y aprobadas por el Comité de Principios Rectores Internacionales para la Investigación Biomédica de Animales de Laboratorio (Comité Institucional de Cuidado y Uso de Animales [CICUAL]) de la FCV-UNLP; Número de protocolo: 55-3-16T.

\section{IV.4.2 Tratamientos nutricionales}

Treinta y seis ovejas donantes y 75 ovejas receptoras adultas fueron asignadas a una dieta de 1,5 (grupo suplementado $S$, donantes $n=19$, receptoras $n$ $=36$ ) o 0,5 veces los requerimientos diarios de mantenimiento (grupo restringido $\mathrm{R}$, donantes $\mathrm{n}=17$, receptoras $\mathrm{n}=39$, respectivamente) desde el inicio del tratamiento de sincronización de estros hasta el día de la recuperación embrionaria 
en donantes (día 7 post estro, entre los días -15 y 7 respecto al estro, 22 días totales) y hasta el día 28 post transferencia embrionaria en hembras receptoras (entre los días -15 y 35 respecto al estro, 50 días totales). Cada uno de los tratamientos de alimentación contó con su repetición correspondiente al igual que en el Experimento II. En el día 7 post estro, un embrión de las hembras donantes S o R fue transferido en una hembra receptora $\mathrm{S}$ o $\mathrm{R}$, generándose los siguientes grupos de receptoras: $S S(n=11), S R(n=11), R S(n=25)$ y $R R(n=28)$, donde la primera de las dos letras se refiere a la procedencia del embrión y la segunda a la madre receptora.

\section{IV.4.3 Sincronización de estros y tratamiento de ovulación múltiple}

Las ovejas donantes recibieron un tratamiento de superovulación mediante esponjas intravaginales (60 mg MAP, Progespon ${ }^{\circledR}$, Syntex, Argentina) durante 14 días y la administración de una dosis reducida de $80 \mathrm{mg}$ totales de FSHp (Folltropin ${ }^{\circledR}-\mathrm{V}$, Bioniche, Canadá), suministrada en 6 aplicaciones decrecientes $(18,18,14,14,8$ y $8 \mathrm{mg})$ cada $12 \mathrm{~h}$ en $\operatorname{los}$ días 12,13 y 14 del tratamiento progestacional. Conjuntamente con la quinta aplicación de FSHp y el retiro de la esponja intravaginal, se aplicaron 200 UI de eCG (Novormon ${ }^{\circledR}$, Syntex, Argentina). La detección de estros se realizó cada 12 h a partir de las 24 h post retiro de esponjas hasta las $36 \mathrm{~h}$, con un macho marcador con arnés.

Las ovejas que manifestaron celo entre las 24 y $36 \mathrm{~h}$ de finalizado el tratamiento progestacional fueron inseminadas a tiempo fijo a las $48 \mathrm{~h}$ post retiro de las esponjas. La inseminación artificial intrauterina se realizó por laparoscopía con semen congelado utilizando una dosis de 100 millones de espermatozoides 
totales/oveja. Las dosis de semen fueron congeladas a partir de un solo carnero, con características seminales óptimas (motilidad masal superior a 4; escala subjetiva 0 , mínima; 5, máxima).

A los 7 días luego de la presentación de los estros se realizó la recuperación quirúrgica de embriones (Gibbons y Cueto, 2010). La metodología de recuperación de embriones fue explicada brevemente en el Ensayo II. Mediante observación laparoscópica, se evaluó el número de cuerpos lúteos (CL) por oveja, determinándose la respuesta ovárica al tratamiento de superovulación. Los embriones colectados se clasificaron morfológicamente mediante lupa estereoscópica en sus aspectos de calidad y desarrollo (IETS, 1998), diferenciándose los embriones Grados 1 y 2 (embriones de buena calidad) de los embriones Grados 3 y 4 (embriones de inferior calidad). Se calcularon las tasas de tasas de recuperación embrionaria y fertilización tal como se describió en el Experimento II. La tasa de embriones transferibles se calculó como el número de embriones 1 y 2/número de embriones totales x 100 .

Un total de 75 embriones fueron transferidos a las ovejas receptoras (1 embrión/oveja), sincronizadas en sus estros mediante tratamiento con progestágenos durante 14 días y la administración de 300 UI de eCG al momento del retiro de la esponja. En las hembras receptoras se realizó la detección del estro (24 y 36h post finalización del tratamiento progestacional) y se comprobó la presencia del CL antes de realizar la siembra embrionaria. La siembra embrionaria se llevó a cabo en forma semi-laparoscópica, a los 7 días luego de la presentación de los estros, mediante una pequeña incisión $(1 \mathrm{~cm})$ en la línea media abdominal y exteriorización del cuerno uterino ipsilateral al/los cuerpos lúteos. Luego de una 
punción en la cara dorsal del cuerno uterino y en su tercio proximal, se depositó un embrión en la luz uterina de cada hembra receptora (Gibbons y Cueto, 2010).

A los 28 días de la transferencia embrionaria, se realizó el diagnóstico ecográfico de gestación (Aloka 500, 5 MHz, Japón, Figura IV.1).

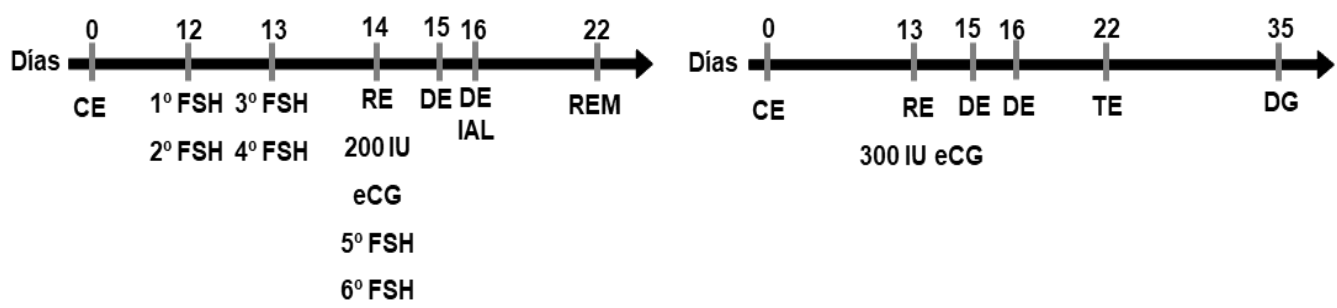

Figura IV.1 Protocolo utilizado para la producción, recuperación y transferencia de embriones en ovejas Merino. CE: colocación de esponjas intravaginales; RE, retiro de esponjas; eCG, gonadotrofina coriónica equina; DE: detección de celos; IAL: inseminación artificial laparoscópica; REM, recuperación embrionaria; TE, transferencia embrionaria; DG, diagnóstico de gestación.

\section{IV.4.4 Muestreos}

El PV y la CC se determinaron cada 15 días desde el inicio hasta la finalización del tratamiento de alimentación. La extracción de sangre, el diagnóstico de gestación y la estimación de las pérdidas embrionarias tardías y fetales se realizaron como se describió en el Experimento I (Figura IV.1).

\section{IV.4.5 Metabolitos y hormonas metabólicas}

Las determinaciones de las concentraciones séricas de metabolitos (AGNE), hormonas esteroideas $\left(\mathrm{P}_{4}\right)$ y hormonas metabólicas (insulina, IGF-1 y leptina) se acreditaron de acuerdo al protocolo descripto en el Experimento I (Figura IV.1). 


\section{IV.4.5 Transcriptos}

Al momento de la recuperación embrionaria (día 8 luego del retiro de la esponja), se obtuvieron biopsias uterinas de ovejas donantes $(S=11$ y $R=15)$ y receptoras $(\mathrm{S}=5$ y $\mathrm{R}=5)$ que fueron conservadas en $\mathrm{N} 2$ líquido hasta su posterior análisis. Sobre estas muestras se determinó la expresión génica uterina de los receptores de: progesterona $(\mathrm{PR})$, factor de crecimiento insulínico (IGF-1R) y leptina (LEPR) mediante PCR en tiempo real. Para ello, se extrajo ARN total de cada muestra de útero utilizando Trizol (Invitrogen), se realizó una precipitación con isopropanol y tratamiento con DNAsa utilizando un kit DNAasas RQ1 (Promega). Para cada muestra, se sintetizó ADN copia (ADNc) mediante transcripción reversa usando una transcriptasa (M-MLV Reverse Transcriptase, Promega) con primers oligo-dT y $1 \mu \mathrm{g}$ de ARN total como molde. Se determinó la expresión génica mediante PCR en tiempo real (qPCR) con cebadores (Integrated DNA Technologies) para cada uno de los genes PR, IGF-1R, LEPR en termociclador LineGene 9600 (Bioer, Tabla IV.1). Los niveles de ARNm hallados para cada gen fueron relativizados a los del gen de referencia $A C T B$ por el método del delta Ct. Las reacciones de PCR en tiempo real fueron realizadas agregando 3 $\mu 1$ de mezcla real 2x (Biodynamics, Argentina), cantidades iguales (isomolares) de cebadores sentido y antisentido (Integrated DNA Technologies), y $4 \mu \mathrm{L}$ de ADNc formando un volumen final de $15 \mu \mathrm{L}$. Se utilizaron las condiciones standard de amplificación que se describen a continuación: 10 min a $95^{\circ} \mathrm{C}$ y 40 ciclos de $20 \mathrm{~s}$ a $95^{\circ} \mathrm{C}, 1 \mathrm{~m}$ a $\mathrm{Tm}^{\circ}, \mathrm{y} 40 \mathrm{~s}$ a $72^{\circ} \mathrm{C}$. 
Tabla IV.I. Secuencia de oligonucleótidos usados para la amplificación de un fragmento de los genes de interés: receptor de progesterona (PR), del receptor de IGF-1 (IGF-1R) y del receptor de leptina (LEPR) y control endógeno $\beta$-actina (ACTB).

\begin{tabular}{lll}
\hline Gen & $N^{\text {o }}$ Acceso & Secuencia Primer \\
\hline \multirow{2}{*}{ PR } & XM_015100878.1 & FO: 5'-GGTCTACCAGCCCTATCTCAAC-3' \\
& & RE: 5'-AGTTATGCTGTCCTTCCATTGC-3' \\
IGF-1R & XM_012098367.2 & FO: 5'-GTCCCTCAAGGATGGAGTCTT-3' \\
& & RE: 5'-CATCAGCTCAAACAGCATGTCAG-3' \\
LEPR & NM_001009763.1 & FO: 5'-GCCACTTGCAGAGAGATGGT-3' \\
& & RE: 5'-GAGAGTCCAGTGAGCCCAAC-3' \\
ACTB & NM_001009784.2 & FO: GCACCCAGCACGATGAAGAT-3' \\
& & RE: TGTAACGCAGCTAACAGTCCG-3' \\
\hline
\end{tabular}

\section{IV.4.6 Análisis estadístico}

Basado en un diseño experimental en bloques completamente aleatorizados, se realizaron los análisis estadísticos correspondientes para las variables consideradas. Las concentraciones de $\mathrm{P}_{4}$, hormonas metabólicas y metabolitos, las tasas de preñez y las pérdidas de gestación fueron analizados con los mismos modelos matemáticos utilizados en el Experimento I, con el agregado del efecto de la interacción entre origen del embrión y el estado nutricional de la hembra receptora. Se realizó un ANOVA de dos vías para comparar las expresiones relativas de ARNm. Las medias de los grupos se compararon por Test de Tukey. Se consideraron diferencias estadísticamente significativas cuando el $\mathrm{P}$ valor fue $\mathrm{P}<0,05$ y se consideró una tendencia a la significancia cuando fue de $\mathrm{P}<0,1$. 


\section{IV.5 RESULTADOS}

\section{IV.5.1 Estado corporal de donantes y receptoras}

Las ovejas donantes y receptoras restringidas nutricionalmente presentaron menor PV y CC que las ovejas que recibieron un tratamiento nutricional de suplementación $(\mathrm{P}<0,05)$.

Las ovejas del ensayo presentaron un PV y CC inicial de $42,4 \pm 0,48 \mathrm{~kg}$ y $2,27 \pm 0,02$. Al finalizar los tratamientos de alimentación, 22 días después, las donantes restringidas presentaron un PV y CC final de $38,3 \pm 0,95 \mathrm{~kg}$ y $1,94 \pm 0,07$ mientras que las donantes suplementadas presentaron un PV y CC final de 42,2 \pm $0,90 \mathrm{~kg}$ y $2,38 \pm 0,07(\mathrm{P}<0,0001)$. En tanto que 50 días después, las receptoras restringidas presentaron un PV y CC final de 35,3 $\pm 0,99 \mathrm{~kg}$ y $1,81 \pm 0,04$ mientras que las receptoras suplementadas presentaron un PV y CC final de 44,6 $\pm 1,03 \mathrm{~kg}$ y $2,66 \pm 0,05(\mathrm{P}<0,0001)$

\section{IV.5.2 Recuperación de embriones y calidad embrionaria}

La tasa de presentación de estros no difirió entre donantes suplementadas y restringidas, obteniéndose una tasa total de estros del 97,2\% (35/36). El 77,1\% $(27 / 35)$ de las ovejas donantes que manifestaron celo respondieron al tratamiento multiovulatorio con FSHp (>3 CL).

Del total de embriones recuperados, el 7,75\% (10/129) se clasificó como embriones de inferior calidad (Grados 3 y 4), proviniendo el 70\% de las donantes restringidas y el restante $30 \%$ de las donantes suplementadas. De estos embriones, se utilizaron 8 de inferior calidad (aprox 10\% por grupo) y 67 fueron embriones de Grados 1 y 2. Asimismo, se obtuvo un mayor porcentaje de blastocistos de las 
donantes suplementadas $(67,5 \%)$ en comparación con las donantes restringidas (36,7\%). Las tasas de recuperación embrionaria, fertilidad y embriones transferibles en ovejas donantes según el tratamiento nutricional se presentan en la tabla IV.2.

Tabla IV.2. Eficiencia reproductiva de la recuperación embrionaria según el tratamiento nutricional (Suplementado $=\mathrm{S}$; Restringido $=\mathrm{R}$ ) en donantes de embriones.

\begin{tabular}{lcc}
\hline & Grupo S (n=12) & Grupo R (n=15) \\
\hline Tasa de recuperación embrionaria (\%) & $51,8 \pm 7,8^{\mathrm{a}}$ & $68,3 \pm 6,9^{\mathrm{a}}$ \\
Tasa de fertilidad (\%) & $85,4 \pm 7,6^{\mathrm{a}}$ & $91,4 \pm 6,8^{\mathrm{a}}$ \\
Tasa de embriones transferibles (\%) & $93,2 \pm 6,0^{\mathrm{a}}$ & $91,4 \pm 5,12^{\mathrm{a}}$ \\
\hline
\end{tabular}

Superíndices en la misma fila indican diferencias significativas $(\mathrm{P}<0,05)$.

\section{IV.5.3 Tasa de preñez post siembra embrionaria}

Al comparar las tasas de preñez entre receptoras restringidas $\mathrm{y}$ suplementadas no se evidenciaron diferencias significativas entre grupos al día 17 de gestación ( 59 vs $72 \%, \mathrm{P}>0,05$ ). Sin embargo, la tasa de preñez al día 35 de gestación presentó una tendencia a la significancia siendo menor en las ovejas restringidas respecto a las ovejas suplementadas ( 49 vs. $64 \%, \mathrm{P}<0,1)$.

La tasa de preñez no evidenció diferencias significativas entre los grupos de receptoras en el día 17 de gestación $(45,64,72$ y 73\% para SR, RR, RS y SS, respectivamente; Tabla IV.3; P >0,05). Sin embargo, las pérdidas embrionarias entre los días 17 y 35 evidenciaron una tendencia a ser mayores en el grupo SR (18\%) con respecto a los otros grupos: 7, 8 y 9\% para RR, RS y SS, respectivamente; $\mathrm{P}<0,1)$. De tal manera que la tasa de preñez al día 35 tendió a ser menor en el grupo SR (27\%) con respecto a los otros grupos: 57, 64 y $64 \%$ para $\mathrm{RR}$, RS y SS, respectivamente; $\mathrm{P}<0,1)$. Es decir que la tasa de sobrevivencia 
embrionaria post transferencia tendió a ser menor en las ovejas receptoras $\mathrm{R}$ que recibieron embriones de ovejas donantes $\mathrm{S}(\mathrm{P}<0,1)$.

Tabla IV.3. Tasas de preñez al día 17 y 35 post estro y tasa de pérdidas embrionarias producidas entre el día 17 y 35 de gestación, según el tratamiento nutricional (Suplementadas [S]; Restringidas [R]) de las ovejas donantes y receptoras de embriones.

\begin{tabular}{lcccc}
\hline & $\begin{array}{c}\text { Donantes S } \\
\text { Receptoras S } \\
\mathbf{n}=11\end{array}$ & $\begin{array}{c}\text { Donantes S } \\
\text { Receptoras R } \\
\mathbf{n = 1 1}\end{array}$ & $\begin{array}{c}\text { Donantes R } \\
\text { Receptoras S } \\
\mathbf{n = 2 5}\end{array}$ & $\begin{array}{c}\text { Donantes R } \\
\text { Receptoras R } \\
\mathbf{n}=\mathbf{2 8}\end{array}$ \\
\hline Preñez Día 17 (\%) & $73^{\mathrm{a}}$ & $45^{\mathrm{a}}$ & $72^{\mathrm{a}}$ & $64^{\mathrm{a}}$ \\
Preñez Día 35 (\%) & $64^{\mathrm{a}}$ & $27^{\mathrm{b}}$ & $64^{\mathrm{a}}$ & $57^{\mathrm{a}}$ \\
$\begin{array}{l}\text { Pérdidas } \\
\text { embrionarias (\%) }\end{array}$ & $9^{\mathrm{a}}$ & $18^{\mathrm{b}}$ & $8^{\mathrm{a}}$ & $7^{\mathrm{a}}$ \\
\hline
\end{tabular}

Superíndices en la misma fila indican diferencias significativas $(\mathrm{P}<0,1)$.

Por otra parte, la tasa de preñez al día 17 post estro obtenida a partir de la transferencia de embriones Grados 3 y 4 fue del 38\% (3/8), mientras que la de los embriones clasificados como Grados 1 y 2 fue del 69\% (46/67; P=0,08). Las tasas de preñez al día 35 post estro fueron del $25 \%$ (2/8) y $60 \%(40 / 67)$ para los embriones de inferior calidad y los embriones Grados 1 y 2, respectivamente $(\mathrm{P}=0,06)$.

No se registraron pérdidas con posterioridad al día 35 de gestación, indicando la ausencia de pérdidas fetales en las ovejas receptoras tanto suplementadas como restringidas.

\section{IV.5.4 Variaciones endocrino-metabólicas}

Las concentraciones de $\mathrm{P}_{4}$ se utilizaron para el diagnóstico temprano de gestación al día 17 post estro, diferenciándose las ovejas no preñadas $(0,65 \pm$ 
$0,40 \mathrm{ng} / \mathrm{ml})$ por sus menores concentraciones respecto a las ovejas preñadas $(6,31 \pm$ 0,45ng/ml) $(\mathrm{P}<0,05)$. Las concentraciones de $\mathrm{P}_{4}$ no presentaron diferencias de acuerdo con el estado nutricional de las receptoras de embriones $(\mathrm{P}>0,05)$.

Las ovejas donantes de embriones restringidas presentaron mayores concentraciones de AGNE con respecto a las ovejas donantes suplementadas $(\mathrm{P}<0,05)$, una tendencia a menores concentraciones de insulina $(\mathrm{P}=0,08)$ pero en estas ovejas no se evidenciaron variaciones en las concentraciones de IGF-1 y leptina entre los tratamientos nutricionales $(\mathrm{P}>0,05)$ (Figura IV.2).

Las ovejas receptoras sometidas a restricción nutricional presentaron menores concentraciones de insulina, IGF-1, leptina y mayores concentraciones de AGNE $(\mathrm{P}<0,05)$. Asimismo, en las receptoras suplementadas, las concentraciones de IGF-1 principalmente y en menor medida las concentraciones de insulina presentaron un marcado incremento a los 15 días post inicio del tratamiento nutricional (día 0), coincidiendo con el momento del estro. Al día 7 post estro se observó un descenso de las concentraciones de estas tres hormonas en las receptoras suplementadas que alcanzó valores similares a las ovejas restringidas en el mismo día (Figura IV.2). 

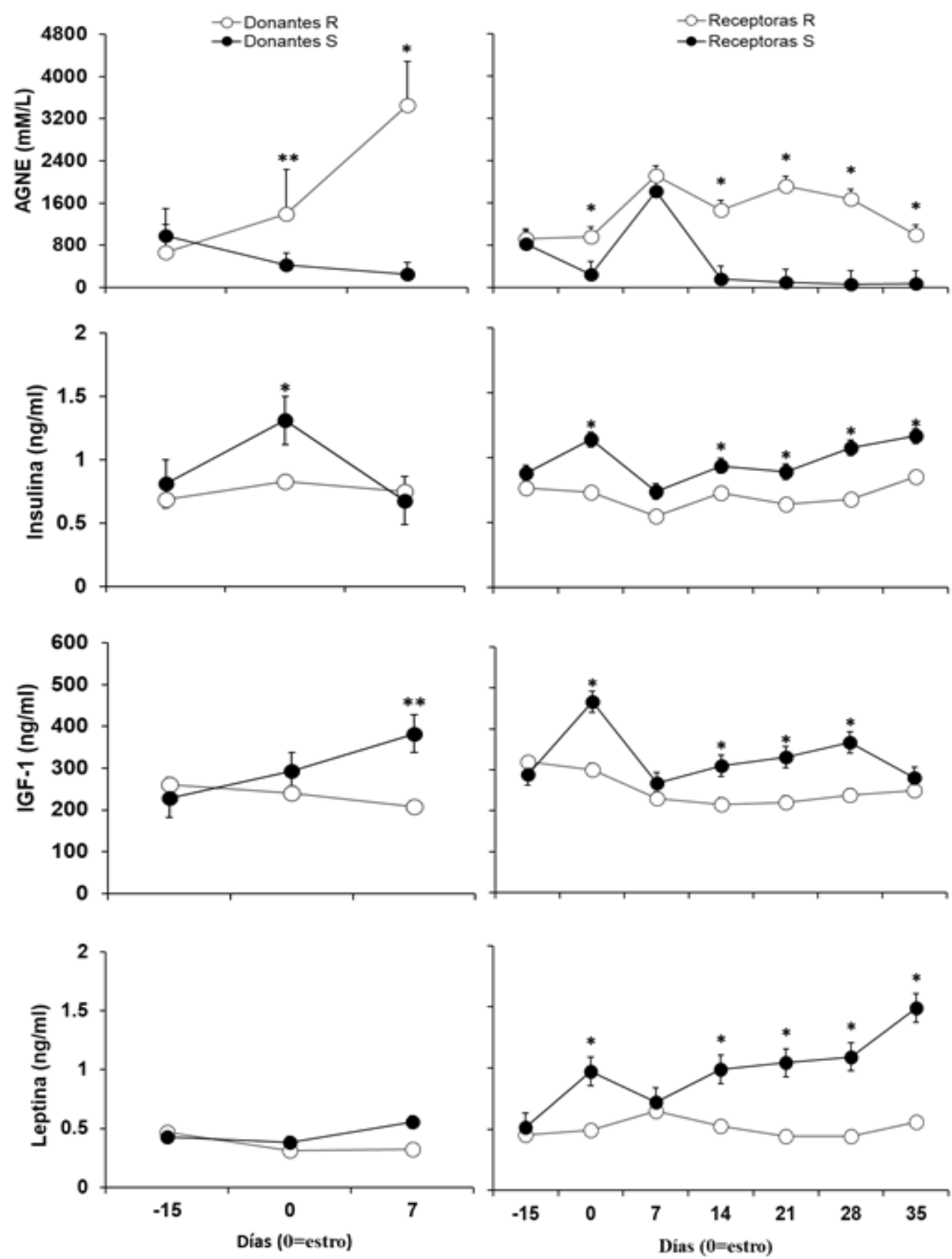

Figura IV.2. Concentraciones séricas de ácidos grasos no esterificados (AGNE), de insulina, del factor de crecimiento similar a la insulina tipo 1 (IGF-1) y de leptina (MMC $\pm \mathrm{ES}$ ), en relación con el tratamiento nutricional (Restringido [R], $\mathrm{n}=25$; Suplementado [S], $\mathrm{n}=25$ ) de ovejas donantes de embriones (panel izquierdo, entre los días -15 y 7 del estro) y de ovejas receptoras de embriones (panel derecho) en ovejas Merino (entre los días -15 y 35 del estro).

Según el estado fisiológico, se observaron menores concentraciones de insulina y leptina en ovejas no preñadas con respecto a las ovejas preñadas 
$(\mathrm{P}<0,05)$. Las concentraciones de AGNE e IGF-1 no variaron por la presencia o ausencia de preñez en las ovejas receptoras de embriones ( $\mathrm{P}>0,05$; Tabla IV.4).

Tabla IV.4. Concentraciones séricas de ácidos grasos no esterificados (AGNE), de insulina, del factor de crecimiento similar a la insulina tipo 1 (IGF-1) y de leptina en relación al diagnóstico de gestación (preñadas, no preñadas) al día 35 en ovejas Merino receptoras de embriones

\begin{tabular}{cccc}
\hline & $\begin{array}{c}\text { Receptoras } \\
\text { No Preñadas }\end{array}$ & $\begin{array}{c}\text { Receptoras } \\
\text { Preñadas }\end{array}$ & P \\
\hline AGNE $(\mu \mathrm{M} / \mathrm{L})$ & $1034 \pm 117^{\mathrm{a}}$ & $921 \pm 114^{\mathrm{a}}$ & NS \\
Insulina $(\mathrm{ng} / \mathrm{ml})$ & $0,75 \pm 0,04^{\mathrm{a}}$ & $0,89 \pm 0,04^{\mathrm{b}}$ & 0,001 \\
IGF-1 $(\mathrm{ng} / \mathrm{ml})$ & $309 \pm 17,6^{\mathrm{a}}$ & $281 \pm 14,6^{\mathrm{a}}$ & $\mathrm{NS}$ \\
& & & \\
Leptina $(\mathrm{ng} / \mathrm{ml})$ & $0,65 \pm 0,06^{\mathrm{a}}$ & $0,84 \pm 0,05^{\mathrm{b}}$ & 0,01
\end{tabular}

Superíndices en la misma fila indican diferencias significativas $(\mathrm{P}<0,05)$.

\section{IV.5.5 Evaluación de la expresión génica uterina}

La expresión génica uterina de los receptores de progesterona (PR), del factor de crecimiento insulínico 1 (IGF-1R) y de leptina (LEPR) fueron determinados por real-time PCR.

Al momento de la transferencia embrionaria, las donantes $\mathrm{R}(0,14 \pm 0,06) \mathrm{y}$ receptoras $\mathrm{R}(0,08 \pm 0,03)$ tuvieron menores niveles de $\mathrm{ARNm}$ en útero para los $\mathrm{PR}$ comparado con las donantes $\mathrm{S}(0,39 \pm 0,15)$ y las receptoras $\mathrm{S}(0,86 \pm 0,0, \mathrm{P}<0,05$; Figura IV.3). Asimismo, los niveles relativos de ARNm para IGF-1R y LEPR en el día 7 post estro fueron menores en las ovejas R (IGF-1R: 0,05 $\pm 0,01$; LEPR: 0,04 $\pm 0,01)$ que en las ovejas S (IGF-1R: $0,15 \pm 0,03$; LEPR: $0,17 \pm 0,04 ; \mathrm{P}<0,05$; Figura IV.4). 


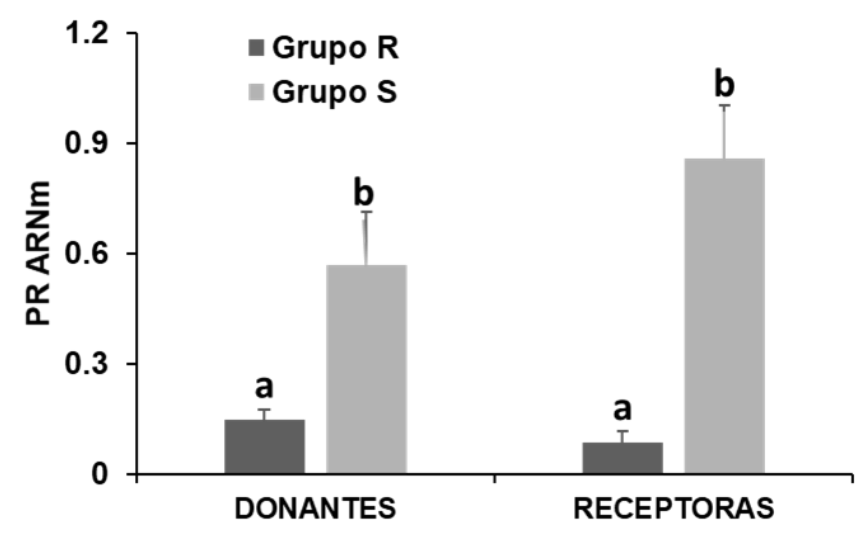

Figura IV.3. Expresión relativa de transcriptos de ARNm del receptor de progesterona (PR) al día 7 post estro, en útero de ovejas donantes y receptoras según el tratamiento nutricional (Suplementadas [S] y Restringidas $[R])$. Superíndices entre barras indican diferencias significativas $(\mathrm{P}<0,05)$.
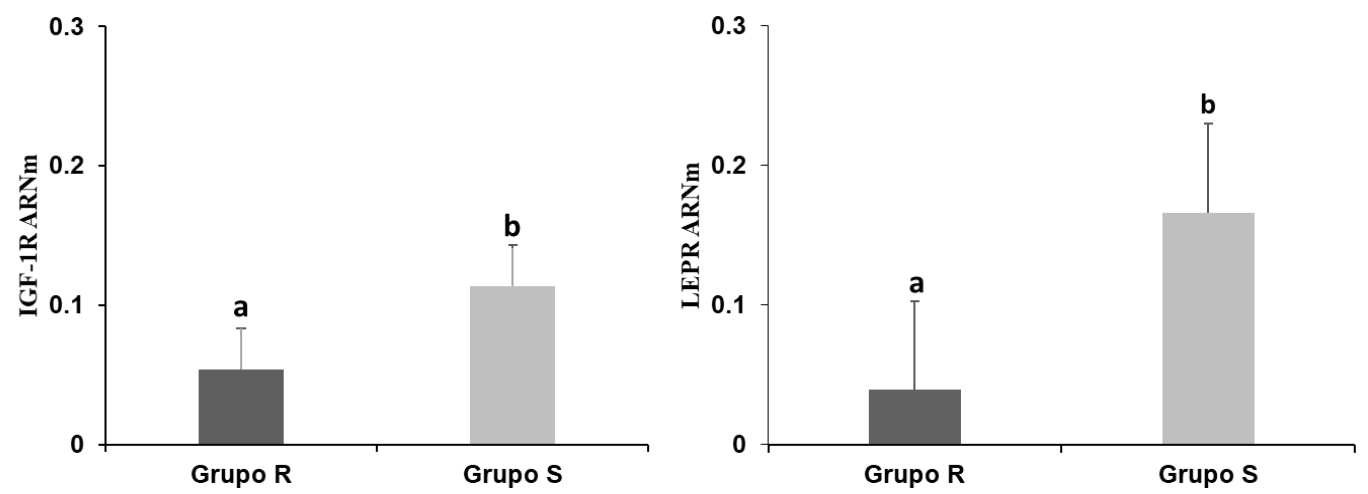

Figura IV.4. Expresión relativa de transcriptos de ARNm del receptor de IGF-1 (IGF-1R) y de leptina (LEPR) al día 7 post estro, en útero según el tratamiento nutricional (Suplementadas [S] y Restringidas [R]). Superíndices entre barras presentan diferencias significativas $(\mathrm{P}<0,05)$.

\section{IV.6 DISCUSIÓN}

\section{Respuesta al tratamiento MOET según el tratamiento nutricional}

Los tratamientos nutricionales aplicados en este estudio lograron una disminución del 17\% del PV inicial y del 20\% de la CC inicial en ovejas receptoras restringidas, así también como una ganancia del 5\% del PV y del 17\% de la CC en ovejas receptoras suplementadas en un período de 50 días. A pesar de que el 
tratamiento nutricional en las ovejas donantes se aplicó desde los 22 días previos al momento de la recuperación de embriones, este tiempo no fue suficiente para que el PV y la CC manifestaran un incremento en las hembras donantes suplementadas. Sin embargo, al considerar las donantes restringidas, estas sufrieron una pérdida de PV y CC del 10 y 5\%, respectivamente.

La ausencia de variación en el estado corporal entre donantes suplementadas y restringidas podría explicar por qué no se obtuvieron diferencias en la respuesta al tratamiento de superovulación y producción de embriones según los tratamientos de alimentación. Otros autores han obtenido menores tasas de recuperación de embriones totales y transferibles en ovejas subnutridas en comparación con ovejas controles (Abecia y col., 2015). Del mismo modo, Borowczyk y col. (2006) reportaron que la subnutrición de ovejas donantes tiene un efecto negativo en la calidad embrionaria presentándose menores tasas de clivaje y desarrollo de blastocistos. Sin embargo, aunque en este estudio, las donantes restringidas presentaron un mayor porcentaje de embriones de inferior calidad, la diferencia no fue significativa ya que se presentó un bajo número de embriones de baja calidad sobre el total de embriones recuperados.

\section{Preñez y mortalidad embrionaria post siembra de embriones}

Al comparar las tasas de preñez entre las receptoras suplementadas y restringidas, no se observaron diferencias estadísticamente significativas entre los grupos R y S al día 17 de gestación. Sin embargo, las ovejas suplementadas presentaron una tendencia a una mayor tasa de preñez al día 35 (64\%), en comparación con las restringidas (49\%), lo que evidencia una reducción del 15\% 
de la fertilidad de los animales subnutridos, lo que indicaría una mayor tasa de mortalidad embrionaria tardía en este último grupo.

Al considerar la comparación según los 4 grupos de receptoras definidos, la tasa de preñez al día 17 de gestación no difirió entre los grupos, al igual que lo reportado por de Brun y col. (2016) que, utilizando el mismo modelo de transferencia embrionaria, no encontraron diferencias en la tasa de preñez al día 18 de gestación, ni tampoco al día 40 de gestación. Sin embargo, en nuestro estudio, al día 35 de gestación y debido a una mayor mortalidad embrionaria, en el grupo de receptoras restringidas que recibieron embriones de donantes suplementadas (SR), se evidenció una tendencia a una menor tasa de preñez respecto a los otros grupos de tratamiento. La tendencia a una mayor mortalidad embrionaria tardía, también reportada por otros autores en períodos similares (de Brun y col., 2016), marca la importancia que tiene el ambiente uterino materno en la supervivencia de los embriones, independientemente de los antecedentes nutricionales previos del embrión. Con estos resultados se pone en evidencia la importancia del ambiente uterino sobre el establecimiento y continuidad de la preñez, ya que la supervivencia del embrión se ve afectada de manera negativa principalmente ante condiciones nutricionales desfavorables que causan alteraciones en el sistema de señales entre el embrión y el ambiente uterino en el que se desarrolla.

\section{Respuesta metabólica al tratamiento nutricional}

En las ovejas donantes de embriones se observaron algunas modificaciones metabólicas en respuesta a los tratamientos nutricionales de restricción y suplementación no tan marcadas como en las ovejas receptoras. Esto es importante 
ya que las respuestas endocrino-metabólicas a un episodio de restricción nutricional dependen de las reservas corporales previas al comienzo del experimento, lo que se denomina memoria metabólica (Chilliard y col., 1998; Zhang y col., 2005; Blache y col., 2006; Fernández-Foren y col., 2011). Los 22 días de tratamiento nutricional aplicados generaron el descenso de PV y CC de las donantes restringidas que se vio reflejado en el aumento de las concentraciones de AGNE y un descenso de las concentraciones de insulina hacia el final del tratamiento, no presentándose diferencias en las concentraciones de IGF-1 y leptina, quizás debido al corto tiempo del tratamiento nutricional aplicado. Contrariamente en ovejas receptoras de embriones, en las cuales el tratamiento nutricional fue más prolongado, el efecto sobre las concentraciones de AGNE y hormonas metabólicas fue más marcado. La restricción nutricional provocó una movilización de las reservas grasas de las madres como se demuestra a través de las concentraciones elevadas de AGNE durante todo el período de tratamiento y menores concentraciones de insulina, IGF1 y leptina. Este aumento en las concentraciones de AGNE era esperable ya que cuando los aportes no satisfacen los requerimientos energéticos, el animal dispone de sus reservas de triglicéridos para su utilización por los diferentes tejidos (Chilliard y col., 1998). Asimismo, la disminución en las concentraciones de insulina es consistente con lo reportado previamente por Abecia y col. (2015) y de Brun y col. (2015). Se ha propuesto que la disminución en las concentraciones de insulina en animales subnutridos es una estrategia para disminuir los requerimientos de energía cuando la disponibilidad de nutrientes es baja (de Brun, 2014). Esto tiene como consecuencia una disminución del anabolismo, lipogénesis y del transporte de glucosa (Flint y col., 2003), poniendo a la insulina como uno de los indicadores 
metabólicos más eficientes en reflejar el estado nutricional de las ovejas (Caldeira y col., 2007a).

La disminución de IGF-1 frente una restricción nutricional es consistente con lo reportado previamente por Sosa y col. (2006). En períodos de subnutrición existe un desacoplamiento del eje somatotrópico provocando una disminución en las concentraciones de IGF-1 (Chilliard y col., 1998; Breier, 1999; Kobayashi y col., 1999; Kim, 2014). Este es un mecanismo que asegura la distribución de nutrientes a los diferentes tejidos cuando la energía disponible es limitada (Fernández-Foren y col., 2011).

La leptina es producida principalmente por el tejido adiposo y está positivamente relacionada con el nivel de grasa corporal (Chilliard y col., 1998; Delavaud y col., 2000; Chilliard y col., 2005). Las ovejas restringidas presentaron una caída en las concentraciones séricas de leptina como ha sido reportado por otros autores (Sosa y col., 2009a; Abecia y col., 2015, de Brun y col., 2015). La reducción en las concentraciones de leptina durante la subnutrición puede actuar como señal para aumentar el apetito, disminuir los gastos de energía y la actividad reproductiva (Chilliard y col., 2000)

El aumento de las concentraciones de AGNE y el descenso en las concentraciones de insulina, IGF-1 y leptina al día 7 post estro en ovejas suplementadas que alcanzó valores similares a las ovejas restringidas, se pudo deber al ayuno que se aplicó previo a la cirugía de recuperación embrionaria.

Por otra parte, se ha descripto que el desarrollo de embriones durante el período de pre-implantación también se ve afectado por estas hormonas (insulina, IGF-1, leptina) y sus receptores, así como por la concentración circulante de AGNE 
(Kaye, 1997). En este estudio, al comparar las concentraciones de los metabolitos y hormonas metabólicas entre receptoras preñadas y no preñadas, se evidenció un efecto del estado fisiológico sobre las concentraciones de insulina y leptina, pero no se evidenció un efecto de la preñez en las concentraciones de IGF-1 ni de AGNE. Esto se corresponde con la importancia de la insulina sobre todas las funciones metabólicas, e inclusive sobre la preñez. En este sentido, se ha descripto la presencia de receptores de insulina presentes en el endometrio materno que regulan la función uterina (Fowden y col., 1989; Gluckman y Pinal, 2003). Por su parte, la leptina ha sido descripta como el más importante regulador metabólico de la actividad reproductiva en especies de laboratorio (Kawamura y col., 2002; Krug y EhrhartBornstein, 2005) y también en rumiantes (Chilliard y col., 2005). Además de su acción a nivel central, es importante tener en cuenta la acción de estas hormonas a nivel local ya que pueden actuar directamente en tejidos periféricos de forma endócrina, parácrina o autócrina pudiendo provocar alteraciones a nivel del entorno uterino que comprometan la preñez (Chilliard y col., 2005).

\section{Expresión génica uterina en donantes y receptoras de embriones}

El estado nutricional de las ovejas tuvo efecto sobre la expresión génica uterina de los receptores estudiados. La expresión del receptor de progesterona (PR) fue menor en el útero de ovejas restringidas a pesar de que este efecto no se vio reflejado en las concentraciones séricas de $\mathrm{P}_{4}$. Este resultado es coincidente con lo reportado previamente por Sosa y col. (2008) en oviducto de ovejas cíclicas subnutridas al día 5 y 14 post estro presentaron una menor expresión de PR. También, Sosa y col. (2006) describieron que la capacidad de unión del PR se vio 
disminuida en ovejas subnutridas al día 5 post estro. Sin embargo, Fernández Foren y col. (2019) no encontraron efecto de la subnutrición sobre la expresión de PR en el útero al día 5 de gestación.

Ya se había establecido que la pre-implantación embrionaria en la oveja depende de las secreciones uterinas, cuya magnitud y composición están moduladas por las acciones de la $\mathrm{P}_{4}$ (Ashworth, 1995). Por lo tanto, cualquier cambio en la capacidad del tejido endometrial para responder a la $\mathrm{P}_{4}$ en las etapas tempranas de la preñez, como por ejemplo una reducción en la cantidad de sus receptores, o cambios en su afinidad, podría alterar el ambiente uterino afectando el desarrollo y la supervivencia del embrión.

La disminución de los niveles plasmáticos de IGF-1 y leptina en animales restringidos nutricionalmente coincide con la menor expresión relativa de transcriptos de los receptores de IGF-1 (IGF-1R) y leptina (LEPR) a nivel uterino, potenciando el efecto de la subnutrición sobre ambas hormonas. La vía de señalización de IGF1/IGF-R ha sido ampliamente estudiada en la implantación embrionaria y en el -diálogo materno fetal tanto en rumiantes (Sponchiado y col., 2017; Yang y col., 2013) como en otras especies (Kang y col., 2015; Forbes y Westwood, 2008). Por su parte, el papel de la leptina en la implantación es fuertemente sugerido por el hecho de que sus receptores se expresan preferentemente en los sitios de implantación en lugar de en el resto del útero en ratones (Yoon y col., 2005). Los resultados obtenidos en el presente ensayo difieren de los reportados por de Brun y col. (2015) en hígado y Fernández Foren y col. (2019) en útero, quienes no encontraron diferencias en la expresión génica del IGF1R y de LEPR al comparar entre ovejas subnutridas y controles. La disminución 
aquí observada es, sin embargo, una nueva señal de la influencia de la nutrición en el ambiente uterino durante el período de implantación que suma evidencia a la reportada en otros aspectos, como el inmunológico (Thiele y col., 2018) o el directamente relacionado con el desarrollo embrionario (Velázquez, 2015; Fleming y col., 2017).

Los cambios en la expresión uterina endometrial entre receptoras restringidas y suplementadas podrían estar influenciando la diferencia en las tasas de preñez halladas, que evidenciaron diferencias marginalmente significativas del $15 \%$.

En resumen, en este estudio la subnutrición en ovejas receptoras afectó la preñez al día 35, presentándose mayores pérdidas embrionarias entre el día 17 y 35 de gestación, cuando el embrión transferido provenía de una hembra suplementada, destacándose que el establecimiento de la preñez obedece principalmente a las condiciones del ambiente uterino en el cual se desarrolla y a la sincronía del embrión y del útero. Asimismo, la restricción nutricional evidenció alteraciones en los principales metabolitos y hormonas metabólicas que regulan el proceso de implantación y desarrollo embrionario, así como en sus receptores, afectando el establecimiento de la preñez en ovejas subnutridas. 


\section{CAPITULO V}

\section{CONCLUSIONES GENERALES}

- Las pérdidas de gestación que se producen en una majada de ovejas Merino en condiciones de cría extensiva son de baja magnitud y ocurren principalmente durante el período de desarrollo embrionario.

- La restricción nutricional durante el preservicio induce la presentación de celos silentes o anestro, lo que explicaría las menores tasas de preñez obtenidas en las majadas ovinas patagónicas cuando las ovejas no presentan una CC adecuada.

- La subnutrición materna afecta la calidad embrionaria "in vitro", sin embargo, los embriones de madres subnutridas desarrollan embriones viables, no siendo afectada la tasa de preñez al día 17 y 35 de gestación.

- El uso de la suplementación estratégica durante el preservicio, en ovejas restringidas, permite anticiparnos a una baja respuesta reproductiva de los vientres, disminuyendo la presentación de celos silentes u ovejas en anestro, contribuyendo a mejorar el porcentaje de señalada anual y la rentabilidad productiva y económica de los productores ovinos de la región.

- La sobrevivencia embrionaria es afectada por las condiciones del ambiente uterino, resaltando la importancia de la sincronía embrio-uterina para lograr el establecimiento y mantenimiento de la preñez.

- El estado nutricional materno influye directamente sobre las concentraciones de AGNE y hormonas metabólicas (GH, insulina, IGF-1 y leptina) que 
favorecen el desarrollo embrionario temprano, así como el establecimiento y mantenimiento de la preñez.

- La expresión de los receptores uterinos de $\mathrm{P}_{4}$, IGF-1 y leptina se presenta disminuida en ovejas con restricción nutricional que junto a las modificaciones en el estado metabólico alteran el ambiente uterino y la sincronía embriomaterna provocando la presentación de mortalidad embrionaria tardía entre el día 17 y 35 de gestación. 


\section{BIBLIOGRAFÍA}

1. Abdel-Mageed I. Body condition scoring of local Ossimi ewes at mating and its impact on fertility and prolificacy. Egyptian Journal of Sheep and Goat Sciences 2009; 4: 37-44.

2. Abecia JA, Rhind SM, Bramley TA, McMillen SR. Steroid production and LH receptor concentrations of ovarian follicles and corpora lutea and associated rates of ova wastage in ewes given high and low levels of food intake before and after mating. Anim. Sci. 1995; 61, 57-62.

3. Abecia JA, Lozano JM, Forcada F, Zarazaga L. Effect of level of dietary energy and protein on embryo survival and progesterone production on day eight of pregnancy in Rasa Aragonesa ewes. Anim. Reprod. Sci. 1997; 48, 209-218.

4. Abecia JA, Forcada F, Lozano JM. A preliminary report on the effect of dietary energy on prostaglandin F $2 \alpha$ production in vitro, interferon-tau synthesis by the conceptus, endometrial progesterone concentration on days 9 and 15 of pregnancy and associated rates of embryo wastage in ewe. Theriogenology 1999; 52 (7), 12031213.

5. Abecia JA, Sosa C, Forcada F, Meikle A. The effect of undernutrition on the establishment of pregnancy in the ewe. Reprod. Nutr. Dev. 2006; 46, 367-378.

6. Abecia JA, Forcada F, Palacín I, Sánchez-Prieto L, Sosa C, Fernández-Foren A, Meikle A. Undernutrition affects embryo quality of superovulated ewes. Zygote 2015; 23(1), 116-124.

7. Ahima RS, Prabakaran D, Mantzoros C, Qu D, Lowell B, Maratos-Flier E. Role of leptin in the neuroendocrine response to fasting. Nature 1997; 382, 250-255.

8. Ainsworth L. Research and technology for increasing the efficiency and output of lamb production systems. Canada Agr. Res. Branch. Tech. Bull. $2^{\circ}, 86$.

9. Arashiro EKN, Ungerfeld R, Clariget RP, Pinto PHN, Balaro MFA, Bragança G M, Brandão FZ. Early pregnancy diagnosis in ewes by subjective assessment of luteal vascularisation using colour Doppler ultrasonography. Theriogenology 2018; 106, 247-252.

10. Ashworth CJ, Bazer FW. Changes in ovine conceptus and endometrial function following asynchronous embryo transfer or administration of progesterone. Biol. Reprod. 1989; 40, 425-433.

11. Ashworth CJ. Maternal and conceptus factors affecting histotrophic nutrition and survival of embryos. Livest. Prod. Sci. 1995; 44, 99-105.

12. Ashworth CJ, Toma LM, Hunter MG. Nutritional effects on oocyte and embryo development in mammals: implications for reproductive efficiency and environmental sustainability. Philosophical Transactions of the Royal Society B: Biological Sciences, 2009; 364(1534), 3351-3361.

13. Azzarini M. Reproducción en ovinos en América Latina. Algunos resultados de la investigación sobre factores determinantes del desempeño reproductivo y su empleo en condiciones de pastoreo. Producción Ovina 1992; 5:7-56.

14. Azzarini M. Potencial reproductivo de los ovinos. In "X Congreso Latinoamericano de Buiatría”. Paisandú, Uruguay 2002; p. 123-130.

15. Banchero G, Quintans G. Manejo antes de la encarnerada para aumentar el porcentaje de mellizos en ovejas Corriedale. In: Jornada Anual de Producción 
Animal. Resultados Experimentales. Unidad Experimental Palo a Pique. INIA Treinta y Tres. Uruguay, octubre 2004; 6-8.

16. Barb CR, Kraeling RR. Role of leptin in the regulation of gonadotropin secretion in farm animals. Anim. Rep. Sci., 2004; 82:155-167.

17. Baril G, Brebion P, Chesné P. Manual de formación práctica para el trasplante de embriones en ovejas y cabras. 1995. FAO, Roma, ISSN 1014-1200.

18. Bathgate RA, Tillmann G, Ivell R. Molecular mechanisms of bovine oxytocin receptor gene regulation. Biol. Reprod. 1998; 58, 160.

19. Becú-Villalobos D, García-Tornadú I, Shroeder G, Salado EE, Gagliostro G, Delavaud C, Chilliard Y, Lacau-Mengido I.M. Effect of fat supplementation on leptin, insulin-like growth factor I, growth hormone, and insulin in cattle. Can J Vet Res. 2007; 70:218-225.

20. Berain JP. La mortalité embryonaire. Bulletin Technique de I' Insemination Artificielle 1984; 32, 15-17.

21. Bilby TR, Sozzi A, López MM, Silvestre FT, Ealy AD, Staples CR, Thatcher WW. Pregnancy, bovine somatotropin, and dietary n-3 fatty acids in lactating dairy cows: I. Ovarian, conceptus, and growth hormone-insulin-like growth factor system responses. J.of Dairy Sci. 2006; 89 (9), 3360-3374.

22. Bispham J, Gopalakrishnan GS, Dandrea J, Wilson V, Budge H, Keisler DH, Broughton Pipkin F, Stephenson T, Symonds ME. Maternal Endocrine Adaptation throughout Pregnancy to Nutritional Manipulation: Consequences for Maternal Plasma Leptin and Cortisol and the Programming of Fetal Adipose Tissue Development. Endocrinology 2003; 144(8):3575-3585.

23. Blache D, Zhang S, Martin GB. Dynamic and integrative aspects of the regulation of reproduction by metabolic status in male sheep. Reprod. Nutr. Dev. 2006; 46, 379-390.

24. Bocquier F, Theriez M, Prachie S, Brelurut A, Alimentacition des ovins. In: INRA (Ed.), Alimentation des bovins, ovins et caprins. Paris, 1988; 249-281.

25. Boland MP, Lonergan $\mathrm{P}, \mathrm{O}^{\prime}$ Callaghan D. Effect of nutrition on endocrine parameters, ovarian physiology, and oocyte and embryo development. Theriogenology 2001; 55,1323-1340.

26. Bonvissuto GL, Somlo RC, Lanciotti ML, Carteau AG, Busso CA. Guías de condición corporal para pastizales naturales de Precordillera, Sierras y Mesetas y Monte Austral de Patagonia. 2008. Ed: INTA. EEA Bariloche.

27. Borowczyk E, Caton JS, Redmer DA, Bilski JJ, Weigl RM, Vonnahme KA, Borowicz PP, Kirsch JD, Kraft KC, Reynolds LP, Grazul-Bilska AT. Effects of plane of nutrition on in vitro fertilization and early embryonic development in sheep. J Anim Sci. 2006; 84(6): 1593-1599.

28. Bran D, Ayesa J, Lopez C. Regiones ecológicas de Río Negro. Comunicación personal. 2000. Laboratorio de Teledetección. INTA EEA Bariloche.

29. Breier B.H. Regulation of protein and energy metabolism by the somatotropic axis. Domest Anim Endocrinol 1999;. 17(2-3): 209-218.

30. Brien FD, Cumming IA, Clarke IJ, Cocks CS. Role of plasma progesterone concentration in early-pregnancy of the ewe. Aust. J. Exp. Agr. 1981; 21, 562-565.

31. Brook CGD, Marshall NJ. Essential endocrinology. 1996. (3th. ed.) Blackwell Science Ltda. Cambridge, U.K. 
32. Buchbinder A, Lang U, Baker RS, Khoury JC, Mershon J, Clark KE. Leptin in the ovine fetus correlates with fetal and placental size. Am. J. obstet. Gynecol. 2001; 185, 786-791.

33. Buratovich O. Uso de la condición corporal. En Actualización en Producción Ovina. San Carlos de Bariloche 4-8 Septiembre 2000; 4-8.

34. Burke CR, Roche JR. Effects of pasture feeding during the periparturient period on postpartum anovulation in grazed dairy cows. J Dairy Sci. 2007; 90(9): 4304-4312.

35. Butler AA, Le Roith, D. Control of growth by the somatropic axis: growth hormone and the insulin-like growth factors have related and independent roles. Annual review of physiology, 2001; 63(1), 141-164.

36. Butler ST, Marr AL, Pelton SH, Radcliff RP, Lucy MC, Butler WR. Insulin restores $\mathrm{GH}$ responsiveness during lactation-induced negative energy balance in dairy cattle: effects on expression of IGF-I and GH receptor 1A. Journal of Endocrinology 2003; 176(2), 205-218.

37. Caldeira RM, Belo AT, Santos CC, Vazques MI, Portugal AV. The effect of body condition score on blood metabolites and hormonal profiles in ewes. Small Rum. Res. 2007(a); 68, 233-241.

38. Caldeira RM, Belo AT, Santos CC, Vazques MI, Portugal AV. The effect of longterm feed restriction and over-nutrition on body condition score, blood metabolites and hormonal profiles in ewes. Small Rum. Res. 2007(b); 68, 242-255.

39. Cheatham B, Kahn CR. Insulin action and the insulin signaling network. Endocr. Rev. 1995; 16(2): 117-142.

40. Chehab FF, Mounzih K, Lu R, Lim ME. Early onset of reproductive function in female mice treated with leptin. Science 1997; 275, 88-90.

41. Chemineau P, Blanc M, Caraty A, Bruneau G, Monget P. Sous-nutrition, reproduction et système nerveux central chez les mammifères: rôle de la leptine. INRA Prod. Anim. 1999; 12 (3), 217-223.

42. Chilliard Y, Bocquier F, Doreau M. Digestive and metabolic adaptations of ruminants to undernutrition, and consequences on reproduction. Reprod. Nutr. Dev. 1998; 38, 131-152.

43. Chilliard Y, Ferlay A, Faulconnier Y, Bonnet M, Rouel J, Bocquier F. Adipose tissue metabolism and its role in adaptations to undernutrition in ruminants. Proc Nutr Soc 2000; 59: 127-134.

44. Chilliard Y, Delavaud C. Bonnet M. Leptín expression in ruminants: Nutritional and physiological regulations in relation with energy metabolismo. Dom Anim Endocrinol 2005; 29: 3-22.

45. Claps L. Actualidad económica de la Producción Ovina en Patagonia Norte. En: Memorias del VIII curso de actualización en producción ovina 2010; 211-218. S. C. Bariloche. Ed: INTA EEA Bariloche.

46. Coppola D, Ouban A, Gilbert-Barness E. Expression of the insulin-like growth factor receptor 1 during human embryogenesis. Fetal and pediatric pathology 2009; 28(2), 47-54.

47. Cosentino IO, Balaro MFA, Arashiro EKN, Santos JDR, da Silva Carvalho AB, Clariget RP, Brandão FZ. Hormonal protocols for early resynchronization of ovulation in ewes: The use of progestagens, eCG, and inclusion of early pregnancy diagnosis with color Doppler ultrasound. Theriogenology 2019; 133, 113-118.

48. Croston D, Pollott G. Planned Sheep Production, second ed. 2009. Blackwell Scientific Publications, Oxford, 207. 
49. Cueto M, García Vinent J, Gibbons A, Wolff M, Arrigo J. Obtención, procesamiento y conservación del semen ovino. Comunicación técnica Producción Animal 1993 N²00, EEA INTA Bariloche.

50. Cueto M, Gibbons A. Conservación seminal e inseminación artificial en ovinos. En: Memorias del VIII curso de actualización en producción ovina 2010; 72-73. S. C. Bariloche. Ed: INTA EEA Bariloche.

51. Cumming IA, Blockey MA, Winfield CG, Parr RA, Williams AH. A study of relationships of breed, time of mating, level of nutrition, live weight, body condition, and face cover to embryo survival in ewes. Journal of Agricultural Science (Cambridge) 1975; 84: 559-565.

52. Daftary SS, Gore AC. IGF-1 in the brain as a regulator of reproductive neuroendocrine function. Experimental Biology and Medicine, 2005; v.230, p.292306.

53. de Brun V, Abecia JA, Fernández-Foren A, Carriquiry M, Forcada F, Vazquez I, Meikle A, Sosa C. Undernutrition and laterality of the corpus luteum affects 461 gene expression in oviduct and uterus of pregnant ewes. S J Agricul Res 2013; 11.

54. de Brun, V. Efecto de la subnutrición materna sobre la gestación temprana en ovinos: énfasis endócrino-metabólico. Tesis de Maestría, 2014, Facultad de Veterinaría, UdelaR.

55. de Brun V, Meikle A, Casal A, Sequeira M, Contreras-Solís I, Carriquiry M, Forcada F, Sosa C, Abecia JA. Periconceptional undernutrition modifies endocrine profiles and hepatic gene expression in sheep. J Anim Phy Nutr 2015; (99) 710718.

56. de Brun V, Meikle A, Fernández-Foren A, Forcada F, Palacín I, Menchaca A, Sosa $\mathrm{C}$, Abecia JA. Failure to establish and maintain a pregnancy in undernourished recipient ewes is associated with a poor endocrine milieu in the early luteal phase. Anim. Reprod. Sci. 2016; 173, 80-86.

57. de la Isla Herrera G, López JRA, Burgos AA, González-Bulnes A. Effect of body condition and season of the year on estrous cycle, estrous, follicular development and ovulation rate in Pelibuey ewes under tropical conditions. Veterinaria México 2010; 41(3), 167-175.

58. Del Valle HF, Elissalde NO, Gagliardini DA, Milovich J. Distribución y Cartografía de la desertificación de la Patagonia-RIA 1997; 28: (1) 1-24.

59. Delavaud C, Bocquier F, Chilliard Y, Keisler DH, Gertler A, Kann G Plasma leptin determination in ruminants: effect of nutritional status and body fatness on plasma leptin concentration assessed by a specific RIA in sheep. J Endocrinol. 2000; 165(2): 519-526.

60. Delavaud C, Ferlay A, Faulconnier Y, Bocquier F, Kann G, Chilliard Y. Plasma leptin concentration in adult cattle: Effects of breed, adiposity, feeding level, and meal intake. J Anim Sci. 2002; 80:1317-1328.

61. Delpino A, González Stagnaro C. Evaluación del comportamiento reproductivo en pequeños rumiantes tropicales utilizando los perfiles de progesterona. Revista Científica FCV-LUZ 1993; Vol. III, N³.

62. DeMayo FJ, Lydon J. New insights into progesterone receptor signaling in the endometrium required for embryo implantation. Journal of Molecular Endocrinology 2019; 1. 
63. Díaz-Torga GS, Mejía ME, González-Iglesias A, Formia N, Becú-Villalobos D, Lacau-Mengido IM. Metabolic cues for puberty onset in free grazing Holstein heifers naturally infected with nematodes. Theriogenology 2001; 56(1), 111-122.

64. Dingwall W, Robinson JJ, Aitken R, Fraser C. Studies on reproduction in profilic ewes. 9. Embryo survival, early fetal growth and within-litter variation in fotal size. J. Agric. Sci. (Camb) 1987; 108, 311-319.

65. Diskin MG, Sreenan JM. Fertilisation and embryonic mortality rates in beef heifers after artificial insemination. J. Reprod. Fertil. 1980; 59, 463-468.

66. Diskin MG, Morris DG. Embryonic and early foetal losses in cattle and other ruminants. Reprod. Domest. Anim. 2008; 43, 260-267.

67. Downing JA, Joss J, Scaramuzzi RJ. Ovulation rate and the concentrations of gonadotrophins and metabolic hormones in ewes infused with glucose during the phase of the oestrus cycle. J. Endocrinol. 1995; 146, 403-410.

68. Dunne LD, Diskin MG, Boland MP, O'Farrell KJ, Sreenan JM. The effect of preand post-insemination plane of nutrition on embryo survival in beef heifers. Anim Sci. 1999; 69:411-417.

69. Dupont J, Scaramuzzi R J, Reverchon M. The effect of nutrition and metabolic status on the development of follicles, oocytes and embryos in ruminants. Animal 2014; 28:1-14.

70. Easdale M. Evaluación económico-financiera de tecnologías en sistemas de producción ovina bajo diferentes contextos. En: Memorias del VIII curso de actualización en producción ovina 2010; 192-210. S. C. Bariloche. Ed: INTA EEA Bariloche.

71. Edey TN. Prenatal mortality in sheep. A review. Anim. Breed. Abstr. 1969; 37, 173- 190.

72. Edey TN. Nutritional stress and pre-implantation mortality in Merino sheep, (19647). General discussion and conclusions. The Journal of Agricultural Science 1970; 74(1), 199-204.

73. Edey TN. Embryo mortality in sheep breeding. In Sheep breeding. Australia. 1976; 400-410. (Proc. Inter. Congr. Muresk).

74. Erfle JD, Fisher LJ, Sauer FD. Interrelationships between blood metabolites and an evaluation of their use as criteria of energy status of cows in early lactation. Can. J. Anim. Sci. 1974; 54: 293-303.

75. Farin CE, Imakawa K, Roberts RM. In situ localization of Mrna for the interferón, ovine trophoblast protein-1, during esrly embryonic development of the sheep. Mol. Endocrinol. 1989; 3, 1099-1107.

76. Faulkner A. In Rook J. A. F., Thomas P. C. eds. Nutritional physiology of farm animals. London 1983; 203-242.

77. Fenwick MA, Llewellyn S, Fitzpatrick R, Kenny DA, Murphy JJ, Patton J, Wathes DC. Negative energy balance in dairy cows is associated with specific changes in IGF-binding protein expression in the oviduct. Reproduction 2008; 135, p.63-75.

78. Fernández Abella D, Álvarez L, Fontaina R, Kintzi H, Nande D, Tagle R. Evaluación de diferentes métodos de sincronización de celo en servicios de primavera. Boletín Técnico de Ciencias Biológicas 1992; 2, 57-68.

79. Fernández Abella D. Principios de fisiología reproductiva ovina. Universidad de la República. Editorial hemisferio sur. 1993. Cap. 8-9.

80. Fernández Abella D, Castells D, Piaggio L, Deleon N. Estudio de la mortalidad embrionaria y fetal en ovinos. I. Efecto de distintas cargas parasitarias y su 
interacción con la alimentación sobre las pérdidas embrionarias y fecundidad. Prod. Ovina 2006; (18):25-31.

81. Fernández Abella D, Formoso D. Estudio de la mortalidad embrionaria y fetal en ovinos II: Efecto de la condición corporal y de la dotación sobre las pérdidas embrionarias y fetales. Prod. Ovina 2007; 19, 5-13.

82. Fernández Abella D, Formoso D, Goicoechea I, Locatelli A, Scarlato S, Ibañez W, Irabuena O. Estudio de la mortalidad embrionaria y fetal en ovinos. III. Efecto de la asignación de forraje y de un estrés pluviométrico artificial sobre la tasa ovulatoria y pérdidas reproductivas en ovejas corriedale. Prod. Ovina 2007; 19:15 $-23$.

83. Fernández-Foren A, Abecia JA, Váquez MI, Forcada F, Sartore I, Carriquiri M, Meikle A, Sosa C. Restricción alimenticia en ovinos: respuesta endocrinometabólica dependiente de las reservas corporales. ITEA 2011; 170, 1-15.

84. Fernández-Foren A, Sosa C, Abecia JA, Vázquez MI, Forcada F, Meikle A. Dietary restriction in sheep: Uterine functionality in ewes with different body reserves during early gestation. Theriogenology 2019; 135, 189-197.

85. Fleming TP, Eckert JJ, Denisenko O. The role of maternal nutrition during the periconceptional period and its effect on offspring phenotype. In Periconception in Physiology and Medicine 2017; 87-105.

86. Flint DJ, Binart N, Kopchick J, Kelly P. Effects of growth hormone and prolactin on adipose tissue development and function. Pituitary 2003; 6(2), 97-102.

87. Forbes K, Westwood M. The IGF axis and placental function. Hormone Research 2008; 69, 129-137.

88. Forcada F, Abecia, JA, Sierra I. Seasonal changes in oestrus activity and ovulation rate in Rasa Aragonesa ewes maintained at two different body condition levels. Small Ruminant Research 1992; 8(4), 313-324.

89. Forcada F, Abecia JA. The effect of nutrition on the seasonality of reproduction in ewes. Reprod. Nutr. Dev. 2006; 46 (4), 355-365.

90. Fowden AL, Hughes P, Comline RS. The effects of insulin on the growth rate of the sheep fetus during late gestation. Q. J. Exp. Physiol. 1989; 74: 703-714.

91. Fowden AL, Forhead JA. Endocrine mechanisms of intrauterine programming. Reproduction 2004; 127, 515-526.

92. Friedman JM, Halaas JL. Leptin and the regulation of body weight in mammals. Nature 1998; 395: 763-770.

93. Gibbons A. Determinación de los factores que afectan la eficiencia reproductiva de las majadas. Presencia 1993; 28, 38-40.

94. Gibbons A, Cueto M. Manual de transferencia de embriones en ovinos y caprinos. 2010; Comunicación técnica Prod.Anim. 559. EEA INTA Bariloche.

95. Gicquel C, Le Bouc Y. Hormonal regulation of fetal growth. Hormone Research in Paediatrics, 2006; 65(Suppl. 3), 28-33.

96. Giraudo CG. El empleo de la condición corporal como indicador del estado nutricional de los ovinos. Rev. Presencia 2009; N54: 32-35. Ed. INTA EEA Bariloche.

97. Giraudo CG, Villagra ES. Algunos aspectos de la producción ovina en Río Negro. Rev. Presencia. 2008 Año XIX-N 52: 19-24. Ed. INTA EEA Bariloche.

98. Giuliodori MJ, Delavaud C, Chilliard Y, Becú-Villalobos D, Lacau-Mengido I, de la Sota RL. High NEFA concentrations around parturition are associated with delayed ovulations in grazing dairy cows. Livestock Science 2011; 141, 123-128. 
99. Gluckman PD, Pinal CS. Regulation of fetal growth by the somatotrophic axis. The Journal of nutrition 2003; 133(5), 1741S-1746S.

100. Godkin JD, Bazer FW, Moffatt J, Sessions F, Roberts RM. Purification and properties of a major, low molecular weight protein released by the trophoblast of sheep blastocysts at day 13-21. J. Reprod. Fertil. 1982; 65, 141-150.

101. Goff A.K. Embryonic signals and survival. Reprod. Domest. Anim. 2002; 37, 133139.

102. Gong JG, Bramley TA, Webb R. The effect of recombinant bovine somatotropin on ovarian function in heifers: follicular populations and peripheral hormones. Biol Reprod 1993; 45, 941-949.

103. Graham JD, Clarke CL. Physiological Action of Progesterone in Target Tissues. Endocr. Rev. 1997; 18, 502-519.

104. Gray CA, Burghardt RC, Johnson GA, Bazer FW, Spencer TE. Evidence that absence of endometrial gland secretions in uterine gland knockout ewes compromises conceptus survival and elongation. Reproduction 2002; 124, 289300.

105. Guillomot M, Michel C, Gaye P, Charlier N, Trojan J, Martal J. Cellular localization of an embryonic interferon, ovine trophoblastin and its mRNA in sheep embryos during early pregnancy. Biology of the Cell 1990; 68, 205-211.

106. Gunn RG, Doney JM, Russel AJF 1972. Embryo mortality in Scottish Blackface ewes as influenced by body condition at mating and by post mating nutrition. Animal Science 1972; 79: 19-25.

107. Gunn RG, Doney JM. The interaction of nutrition and body condition at mating on ovulation rate and early embryo mortality in Scottish Blackface ewes. The Journal of Agricultural Science, 1975; 85(3), 465-470.

108. Gunn RG, Doney JM 1979. Fertility in Cheviot ewes. 1. The effect of body condition at mating on ovulation rate and early embryo mortality in North and South country Cheviot ewes. Animal Production 1979; 29: 11-16.

109. Gunn RG, Smith WF, Senior AJ, Barthram E, Sim DA, Hunter EA 1991. Premating herbage intake and the reproductive performance of north country Cheviot ewes in different levels of body condition. 1991; Animal Production 52: 149-156.

110. Hafez E. Reproducción e Inseminación Artificial en Animales. 1996. Interamericana McGraw-Hill. México.

111. Hansen TR, Imakawa K, Polites HG, Marotti KR, Anthony RV, Roberts RM. Interferón RNA of embryonic origin is expressed transiently during early pregnancy in the ewe. J. Biol. Chem. 1988; 263, 12801-4.

112. Harrison LM, Kenny N, Niswender GD. Progesterone production, LH receptors, and oxytocin secretion by ovine luteal cell types on days 6,10 and 15 of the oestrous cycle and day 25 of pregnancy. Reproduction, 1987; 79(2), 539-548.

113. Hua KM, Hodgkinson SCS, Bass JJ. Differential regulation of plasma levels of insulin-like growth factors-I and II by nutrition, age and growth hormone treatment in sheep. J. Endocrin. 1995; 147, 507-516.

114. IETS 1998. Manual of the International Embryo Transfer Society. Stringfellow, D.A., Seidel, D.A. (Editors). Savoy, Illinois.

115. Imakawa K, Anthony RV, Kazemi M, Marotti KR, Polites HG, Roberts RM. Interferon-like sequence of ovine trophoblast protein secreted by embryonic trophectoderm. Nature 1987; 330, 377-379. 
116. Inskeep EK, Dailey RA. Embryonic death in cattle. Vet. Clin. N. Am. Food 2005; A 21, 437-461.

117. Ingvartsen KL, Andersen JB. Integration of metabolism and intake regulation: a review focusing on periparturient animals. J Dairy Sci. 2000; 83(7):1573-1597.

118. Jimeno V, Castro T, Rebollar PG. Interacción nutrición-reproducción en ovino de leche. XVII Curso de Especialización FEDNA 2002.

119. Kadokawa H, Briegel JR, Blackberry MA, Blache D, Martin GB, Adams NR. Reproduction and plasma concentrations of leptin, insulin and insulin-like growth factor 1 in growthhormone-transgenic female sheep before and after artificial insemination. Reproduction Fertility and Development 2003; 15, 47-53.

120. Kakar MA, Maddocks S, Lorimer MF, Kleemann DO, Rudiger SR, Hartwich KM, Walker SK. The effect of peri-conception nutrition on embryo quality in the superovulated ewe. Theriogenology 2005; 64, 1090-1103.

121. Kang, Y. J., Lees, M., Matthews, L. C., Kimber, S. J., Forbes, K., Aplin, J. D. miR145 suppresses embryo-epithelial juxtacrine communication at implantation by modulating maternal IGF1R. Journal of cell science 2015; 128 (4), 804-814.

122. Kawamura K, Sato N, Fukuda J, Kodama H, Kumagai J, Tanikawa H, Nakamura A, Tanaka T. Leptin promotores the development of mouse preimplentacipn embryos in vitro. Endocrinol. 2002; 143, 1922-1931.

123. Kaye PL. Preimplantation growth factor physiology. Rev. Reprod. 1997; 2, 121 127.

124. Kelly RW, Wilkins JF, Newnham JP. Fetal mortality from day 30 of pregnancy in Merino ewes offered different levels of nutrition. Australian Journal of Experimental Agriculture, 1989; 29(3), 339-342.

125. Kenyon PR, Maloney SK, Blache D. Review of sheep body condition score in relation to production characteristics. New Zealand Journal of Agricultural Research 2014; 57(1), 38-64.

126. Ketelslegers JM, Maiter D, Maes M, Underwood LE, Thissen JP. Nutritional regulation of insulin-like growth factor-I. Metabolism-Clinical and Experimental $1995 ; 44,50-57$

127. Kiani A, Nielsen MO, Tauson AH, Tygesen MP, Husted SM, Chwalibog A. Longterm effects of foetal undernutrition on intermediary metabolism in growing lambs, Arch. of Anim. Nut. 2011; 65:1, 46-54.

128. Kim JW. Modulation of the Somatotropic Axis in Periparturient Dairy Cows. Asian Australas. J. Anim. Sci. 2014; 27 (1): 147-154.

129. Kleemann DO, Walker SK, Walkley JRW, Smith DH, Grimson RJ, Seamark RF. Fertilization and embryo loss in Booroola Merino $\times$ South Australian Merino ewes: effect of the F gene. Theriogenology 1990; 33(2), 487-498.

130. Kleemann DO, Walker SK, Grimson RJ, Smith DH, Grosser TI, Seamark RF. Exogenous progesterone and embryo survival in Booroola-cross ewes. Reproduction, Fertility and Development 1991; 3(1), 71-77.

131. Kleemann DW, Walker SK. Fertility in South Australian commercial Merino flocks: sources of reproductive wastage. Theriogenology 2005(a); 63: 2416-2433.

132. Kleemann DO, Walker SK. Fertility in South Australian commercial Merino flocks: relationships between reproductive traits and environmental cues. Theriogenology 2005(b); 63: 2416-2433.

133. Kobayashi Y, Boyd CK, Bracken CJ, Lamberson WR, Keisler DH, Lucy MC. Reduced growth hormone receptor (GHR) messenger ribonucleic acid in liver of 
periparturient cattle is caused by a specific down-regulation of GHR 1A that is associated with decreased insulin-like growth factor I. Endocrinology 1999; 140(9): 3947-3954.

134. Kose M, Kaya MS, Aydilek N, Kucukaslan I, Bayril T, Bademkiran S, Atli MO. Expression profile of interferon tau-stimulated genes in ovine peripheral blood leukocytes during embryonic death. Theriogenology 2016; 85(6), 1161-1166.

135. Krug AW, Ehrhart-Bornstein M. Newly discovered endocrine functions of white adipose tissue: possible relevance in obesityrelated diseases. Cell Mol Life Sci, 2005; 62:1359-1362.

136. Lacau-Mengido IM, Mejía ME, Díaz-Torga GS, Gonzalez-Iglesias A, Formía N, Libertun C, Becú-Villalobos D. Endocrine studies in ivermectin-treated heifers from birth to puberty. J. Anim. Sci. 2000; 44 78:817-824.

137. Lea RG, Andrade LP, Rae MT, Hannah LT, Kyle CE, Murray JF, Rhind SM, Miller DW. Effects of maternal undernutrition during early pregnancy on apoptosis regulators in the ovine fetal ovary. Reproduction 2006; 131, 113-124.

138. Leese HJ. Metabolic control during preimplantation mammalian development. Hum. Reprod. Uptade 1995; 1, 63-72.

139. Lenz Souza MI, Ramírez Benavides GF, Uribe Velásquez LF. Papel del factor de crecimiento semejante a la insulina (IGF-1) en la regulación de la función ovárica. Biosalud, 2007; 6, 149-159.

140. Le Roith, D., Bondy, C., Yakar, S., Liu, J. L., Butler, A. 2001. The somatomedin hypothesis: 2001. Endocrine reviews, 22(1), 53-74.

141. Lima PF, Oliveira LA, Santos MHB, Reichenbach, HD, Weppert M, Paula-Lopes FF, Cavalcanti Neto CC, Goncalves, PBD. Effect of retinoids and growth factor on in vitro bovine embryos produced under chemically defined conditions. Anim. Reprod. Sci. 2006; 95, 184-192.

142. Lindsay D, Martin G, Williams I. Nutrition and reproduction. Reprod. Domest. Anim. 1993; 459-491.

143. Lozano JM, Abecia JA, Forcada F, Zarazaga L, Alfaro B. Effect of undernutrition on the distribution of progesterone in the uterus of ewes during the luteal phase of the estrous cycle. Theriogenology 1998(a); 49, 539-546.

144. Lozano JM, Abecia A, Forcada F. Efecto de la subnutrición sobre la mortalidad embrionaria, la producción in vitro de PGF2 alfa y la síntesis de interferon-tau por el embrión los días 9 y 15 de gestación en ganado ovino. Producción Ovina y Caprina 1998(b); XXIII: 559-561.

145. Lozano JM, Lonergan P, Boland MP, O'Callaghan D. Influence of nutrition on the effectiveness of superovulation programmes in ewes: effect on oocyte quality and post-fertilization development. Reproduction 2003; 125, 543-553.

146. MacLaughlin SM, Walker SK, Kleemann DO, Tosh DN, McMillen IC. Periconceptional undernutrition and being a twin each alter kidney development in the sheep fetus during early gestation. Am. J. Physiol. Regul. Integr. Comp. Physiol. 2010; 298: R692-R699.

147. Manazza J. Condición Corporal en ovinos. Visión Rural 13(60). Grupo Sanidad Animal INTA Balcarce. www.produccion-animal.com.ar

148. Martal J, Chene N, Camous S, Huynh L, Lantier F, Hermier P, L'haridon R, Charpigny G, Charlier M, Chaouat G. Recent developments and potentialities for reducing embryo mortality in ruminants: the role of IFN-tau and other cytokines in early pregnancy. Reprod. Fertil. Dev. 1997; 9, 355-80. 
149. Martin G, Thomas G. Roles of communication between the hypothalamus pituitary gland and ovary in the breeding activity of ewes. En: "Reproductive physiology of Merino sheep. Concepts and Consequences". School of Agriculture. Anim. Sci. University of Western Australia: Perth. 1990. Eds. C.M. Oldham, G.B. Martin I.W. Purvis.

150. Martin GB, Rodger J, Blache D. Nutritional and environmental effects on reproduction in small ruminants. Reprod. Fertil. Dev. 2004(a); 16, 491-501.

151. McEvoy TG, Robinson JJ, Aitken RP, Robertson IS. Melatonin treatment of embryo donor and recipient ewes during anestrus affects their endocrine status, but not ovulation rate, embryo survival or pregnancy. Theriogenology 1998; 49, $943-$ 955.

152. McNeilly AS, Jonassen JA, Rhind SM. Reduced ovarian follicular development as a consequence of low body condition in ewes. Acta Endocrinol (Copenh) 1987; $115,75-83$.

153. McPhee IM, Tiberghien MP. Assessment of pregnancy in sheep by analysis of plasma progesterone using an amplified enzyme immunoassay technique. Vet. Rec. 1987; 121: 63-65.

154. Molina A, Gallego L. Efecto del nivel de reservas corporales en distintas épocas del año sobre algunos parámetros productivos en ovejas Manchegas. Invest. Agr. Prod. Sanid. Anim. 1993; 8: 127-137.

155. Molina A, Gallego L, Torres A, Vergara H. Effect of mating season and level of body reserves on fertility and prolificacy of Manchega ewes. Small Rum. Res. 1994; 14: 209-217.

156. Moor RM, Rowson LE, Hay MF, Caldwell BV. The corpus luteum of the sheep: effect of the conceptus on luteal function at several stages during pregnancy. J. Endocrinol. 1969; 43, 301-307.

157. Moschos S, Chan JL, Mantzoros CS. Leptin and reproduction: a review. Fertil. Steril. 2002; 77, 433-444.

158. Mueller J. Introducción a la producción ovina Argentina. En: Memorias del VII curso de actualización en producción ovina 2005 p1-8. S. C. Bariloche. Ed: INTA EEA Bariloche.

159. Muñoz-Gutiérrez M, Findlay PA, Adam CL, Wax G, Campbell BK, Kendall NR, Khalid M, Fosberg M, Scaramuzzi RJ. The ovarían expression of mRNAs for aromatase, IGF-I receptor, IGF-binding protein-2, -4 and -5 , leptin and leptin receptor in cycling ewes after three days of leptin infusión. Reprod. 2005; 130, 869881.

160. National Research Council. 8va Edición. 2011. Guide for the Care and Use of Laboratory Animals. The National Academies Press. [Online] https:/grants.nih.gov/grants/olaw/guide-for-the-care-and-use-of-laboratoryanimals.pdf

161. Newton JE, Betts JE, Wilde R. The effect of body condition and time of mating on the reproductive performance of Masham ewes. Animal Production 1980; 30: 253260.

162. Niswender GD, Nett TM. Corpus luteum and its control in infraprimate species. In "The Physiology of Reproduction" 1994; 781- 816. Eds Knobil, E. y Neill J.D. (Raven Press, New York).

163. O'Callaghan D, Boland MP. Nutritional effects on ovulation, embryo development and the establishment of pregnancy in ruminants. Anim. Sci. 1999; 68, 299-314. 
164. O'Callaghan D, Yaakub H, Hyttel P, Spicer L, Boland M. Effect of nutrition and superovulation on oocyte morphology, follicular fluid composition and systemic hormone concentrations in ewes. J. Reprod. Fertil. 2000; 118: 303-313.

165. Oldham CM, Lindsay DR. Laparoscopy in the ewe: a photographic record of the ovarian activity of ewes experiencing normal or abnormal oestrous cycles. Anim. Reprod. Sci. 1980; 3: 119-124.

166. Oregui LM. Estudio del manejo de la alimentación en los rebaños de raza Latxa y su influencia sobre los resultados reproductivos y de producción de leche. Tesis Doctoral $1992 \mathrm{~N}^{\circ}$ 18. Facultad de Veterinaria, Universidad Complutense de Madrid. España.

167. Parr RA, Cumming IA, Clarke IJ. Effect of maternal nutrition and plasma progesterone concentrations on survival and growth of the sheep embryo in early gestation. J Agric Sci Camb 1982; 98: 39-46.

168. Parr RA, Davis IF, Fairclough RJ, Miles MA. Overfeeding during early pregnancy reduces peripheral progesterone concentration and pregnancy rate in sheep. J. Reprod. Fertil. 1987; 80, 317-320.

169. Parr RA. Nutrition-progesterone interactions during early pregnancy in sheep. J. Fertil. Dev. 1992; 4, 297-300.

170. Peña M, Góngora A, Estrada J. Factores de crecimiento en el desarrollo folicular, embrionario temprano e implantación. Implicaciones en la producción de embriones Bovinos. Revista MVZ Córdoba 2007; 12, 942-954.

171. Peura TT, Kleemann DO, Rudiger SR, Nattrass GS, McLaughlan CJ, Walker SK. Effect of nutrition of oocyte donor on the outcomes of somatic cell nuclear transfer in the sheep. Biology of reproduction 2003; 68(1), 45-50.

172. Rhind SM, Doney JM, Gunn RG, Leslie ID. Effects of body condition and environmental stress on ovulation rate, embryo survival, and associated plasma follicle stimulating hormone, luteinizing hormone, prolactin and progesterone profiles in Scottish Blackface ewes. Animal Production 1984; 38:201-209.

173. Rhind SM, Leslie ID, Gunn RG, Doney JM. Plasma FSH, LH, prolactin and progesterone profiles of cheviot ewes with different levels of intake before and after mating, and associated effects on reproductive-performance. Anim Reprod Sci $1985 ; 8,301-313$.

174. Rhind SM, Martin GB, Mcmillen S, Tsonis CG, Mcneilly AS. Effect of level of food intake of ewes on the secretion of LH and FSH and on the pituitary response to gonadotrophin releasing hormone in ovariectomized ewes. J. Endocrinol. 1989(a); 121, 325-30.

175. Rhind SM, Mckelvey WAC, Mcmillen S, Gunn RG, Elston DA. Effect of restricted food-intake, before and or after mating, on the reproductive performance of greyface ewes. Anim. Prod. 1989(b).; 48, 149-155.

176. Rhind SM, Mcmillen S, Wetherill GZ, Mckelvey WAC, Gunn RG. Effects of low levels of food intake before and/or after mating on gonadotrophin and progesterone profiles in Greyface ewes. Anim. Prod. 1989(c). 49, 267-273.

177. Rhind SM. Nutrition: its effect on reproductive performance and its control in female sheep and goats. In "Progress in sheep and goat research" 1992; 25-52. Ed. Speedy, A.W. (CAB International, Wallingford).

178. Rhoads RP, Kim JW, Leury BJ, Baumgard LH, Segoale N, Frank SJ, Bauman DE, Boisclair YR. Insulin increases the abundance of the growth hormone receptor in liver and adipose tissue of periparturient cows. J. Nutr. 2004; 134, 1020-7. 
179. Roberts RM. Conceptus interferons and maternal recognition of pregnancy. Biol Reprod 1989; 40, 449-452.

180. Roberts RM, Cross JC, Leaman DW. Interferons as hormones of pregnancy. Endocr. Rev. 1992; 13, 432-452.

181. Robinson JJ. Energy requirements of ewes during late pregnancy and early lactation. Vet. Rec. 1980; 106: 282-284.

182. Robinson JJ. Nutrition and Reproduction. Anim. Reprod. Sci. 1996; 42(1-4), 2534.

183. Rondon Z, Forcada F, Zarazaga L, Abecia JA, Lozano JM Oestrous activity, ovulation rates and plasma melatonin concentrations in Rasa Aragonesa ewes maintained at two different and constant body condition scores levels and implanted or reimplanted with melatonin. Animal Reproduction Science 1996; 41: 225-236.

184. Rumball CWH, Oliver MH, Thorstensen EB, Jaquiery AL, Husted SM, Harding JE, Bloomfield FH. Effects of twinning and periconceptional undernutrition on lategestation hypothalamic-pituitary-adrenal axis function in ovine pregnancy. Endocrinology 2008; 149(3), 1163-1172.

185. Russel AFJ, Doney JM, Reid RL. The use of biochemical parameters in controlling nutrition state in pregnancy ewes and the effect of undernouridhement during pregnancy on lamb birth weight. J. Agric. Camb. 1967; 68:351-358.

186. Russel AJF, Doney JM, Gunn RG. Subjective assessment of body fat in live sheep. J. Agric. Sci. 1969; 72, 451-454.

187. Russel AJF. The nutririon of the pregnant ewe. En "The Management and Diseases of Sheep". Editado por British Council. Londres, 1979; pp: 221- 241.

188. Russel AJF. Nutrition of the pregnant ewe, In Practice 1985; 7: 23-28.

189. Rutter B, Russo AF. Fundamentos de la fisiología de la gestación y el parto de los animales domésticos. 2002. Ed. Eudeba.

190. Sartori R, Sartor-Bergfelt R, Mertens SA, Guenther JN, Parrish JJ, Wiltbank MC. Fertilization and early embryonic development in heifers and lactating cows in summer and lactating and dry cows in winter. J. Dairy Sci. 2002; 85, 2803-2812.

191. SAS. SAS and STAT User's Guide, Release 9.1. SAS Institute Inc. Cary, NC, USA, 2003.

192. Scaramuzzi RJ, Adams NR, Baird DT, Campbell BK, Downing JA,0 Findlay JK, Henderson KM, Martin GB, McNatty KP, McNeilly AS, Tsonis CG. A model for follicles selection and the determination of ovulation rate in the ewe. Reprod Fertil Dev 1993; 5, 459-478.

193. Scaramuzzi R, Campbell B, Downing J, Kendall N, Khalid M, Muñoz-Gutierrez $\mathrm{M}$, Somchit A. A review of the effects of supplementary nutrition in the ewe on the concentrations of reproductive and metabolic hormones and the mechanisms that regulate folliculogenesis and ovulation rate. Rep. Nut. Dev. 2006; 46, 339-354.

194. Short RV. Implantation and the maternal recognition of pregnancy. In "Ciba Foundation Symposium on Foetal Autonomy", 1969; 2-26. Eds Wolstenholm, G.E.W. y O'Connor, M. (Churchill Livingston, London).

195. Siffredi GL, Boggio F, Giorgetti H, Ayesa JA, Kröpfl A, Alvarez JM. Guía para la evaluación de pastizales: Para las áreas eclógicas de Sierras y Mesetas Occidentales y de Monte de Patagonia Norte. 2011. Ed. INTA.

196. Smith JF. A Review of recent developments on the effect of nutrition on ovulation rate (the flushing) effect with particular reference to research at Ruakura. Proceedings of the New Zealand Society of Animal production 1991; 51: 15-23. 
197. Soriano A. Los distritos florísticos de la provincia patagónica. Rev. Invest. Agr. 1954; 10, 4. pp. 323-357.

198. Sosa C, Abecia JA, Forcada F, Viñoles C, Tasende C, Valares JA, Palacin I, Martin GB, Meikle A. Effect of undernutrition on uterine progesterone and oestrogen receptors and on endocrine profiles during the ovine oestrous cycle. Reprod. Fertil. Dev. 2006; 18, 447-458.

199. Sosa C, Abecia JA, Forcada F, Meikle A. Undernutrition reduces the oviductal mRNA expression of progesterone and oestrogen receptors in sheep. The veterinary journal 2008; 175(3), 413-415.

200. Sosa C, Abecia JA, Carriquiry M, Forcada F, Martin GB, Palacín I, Meikle M. Early pregnancy alters the metabolic responses to restricted nutrition in sheep. Domestic. Anim. Endocrin. 2009(a); 36, 13-23.

201. Sosa C, Abecia JA, Carriquiry M, Vázquez MI,Fernández-Foren A, Talmon M, Forcada F, Meikle A. Effect of undernutrition on the uterine environment during maternal recognition of pregnancy in sheep. Reprod. Fertil. Dev. 2009(b), 21, 113.

202. Spencer TE, Bazer FW. Ovine interferón tau suppresses transcription of the estrogen receptor and oxytocin receptor genes in the ovine endometrium. Endocrinol 1996; 137, 1144-1147.

203. Spencer TE, Ott TL, Bazer FW. Expression of interferon regulatory factors one and two in the ovine endometrium: effects of pregnancy and ovine interferon tau. Biol Reprod 1998; 58, 1154-1162.

204. Spencer TE, Burghardt RC, Johnson GA, Bazer FW. Conceptus signals for establishment and maintenance of pregnancy. Anim. Reprod. Sci. 2004; 82-83, 53750 .

205. Sponchiado M, Gomes NS, Fontes PK, Martins T, del Collado M, de Assumpcao Pastore A, Binelli M. Pre-hatching embryo-dependent and-independent programming of endometrial function in cattle. PloS one 2017; 12(4).

206. Stefanello JR, Barreta ME, Porciuncula PM, Arruda JN, Oliveira JF, Oliveira MA, Gonçalves PB. Effect of angiotensin II with follicle cells and insulin-like growth factor-I or insulin on bovine oocyte maturation and embryo development. Theriogenology 2006; 66, 2068-2076.

207. Stewart RE, Spicer LJ, Hamilton TD, Keefer BE. Effects of Insulin-Like Growth factor 1 and Insulin on proliferation and on basal and luteinizing hormone-Induced steroidogenesis of bovine thecal cells: Involvement of glucose and receptors for insulin-like growth Factor I and luteinizing hormone. J. Anim. Sci. 1995; 73: 37193731 .

208. Tang $\mathrm{CH}$, Akabayashi A, Manitiu A, Leibowitz S. Hypothalamic galanin gene expression and peptide levels in relation circulating insulin: Possible role in energy balance. Neuroendocrinology. 1997; 65: 265-275.

209. Thiele K, Diao L, Arck PC. Immunometabolism, pregnancy, and nutrition. In Seminars in immunopathology 2018; 40: 2, 157-174.

210. Thimonier J. Détermination de l'état physiologique des femelles par analyse des niveaux de5 progestérone. INRA Prod. Anim. 2000; 13, 177-183.

211. Thissen JP, Ketelslegers JM, Underwood LE. Nutritional regulation of the insulinlike growth factors. Endocr Rev. 1994; 15, 80-101.

212. Thomas GB, Mercer JE, Karalis T, Rao A, Cummins JT, Clarke IJ. Effect of restricted feeding on the concentrations of growth hormone $(\mathrm{GH})$, gonadotropins, 
and prolactin (PRL) in plasma, and on the amounts of messenger ribonucleic acid for $\mathrm{GH}$, gonadotropin subunits, and PRL in the pituitary glands of adult ovariectomized ewes. Endocrinol 1990; 126, 1361-1367.

213. Topps JH, Thompson JK. Blood characteristics and the nutrition of ruminants. HMSO 1984.

214. Torres S, Rebours C, Rombauts P, André D, Bertin J, Terqui, M. Conditions of embryonic development in the ewe after modification of the hormone balance of the dam. Animal Reproduction Science 1983; 6(1), 25-33.

215. Velázquez MA, Spicer LJ, Wathes DC. The role of endocrine insulin-like growht factor-I (IGF-I) in female bovine reproduction. Domestic Animal Endocrinology 2008; v.35, p.325-342.

216. Velázquez MA, Hermann D, Kues WA, Niemann H. 2011. Increased apoptosis in bovine blastocysts exposed to high levels of IGF1 is not associated with downregulation of the IGF1 receptor. Reproduction, 141(1), 91.

217. Velázquez MA. Impact of maternal malnutrition during the periconceptional period on mammalian preimplantation embryo development. Domest Anim. Endocrinol. 2015; 51, 27-45.

218. Vera y Vega, A. Alimentación y pastoreo del ganado ovino. Monografías, 1986; (87), 189-217.

219. Villar L. Alimentación estratégica de la oveja antes del parto. (Ed) INTA. EEA Bariloche. Presencia 2011; 58, pp.28-31.

220. Viñoles C, Forsberg M, Banchero G, Rubianes E. Ovarian follicular dynamics and endrocrine profiles in Polwarth ewes with high and low body condition. Animal Science 2002; 74: 539-545.

221. Viñoles C, Glover KMM, Paganoni BL, Milton JTB, Martin GB. Embryo losses in sheep during short-term nutritional supplementation. Reproduction, Fertility and Development 2012; 24(8), 1040-1047.

222. Walsh SW, Williams EJ, Evans ACO. A review of the causes of poor fertility in high milk producing dairy cows. Anim. Reprod. Sci. 2011; 123, 127-138.

223. Ward PR. Bases moleculares de la endocrinología. 1988 Editorial Univerisdad de Concepción. Concepción, Chile.

224. Wathes DC, Reynolds TS, Robinson RS, Stevenson KR. Role of the insulin-like growth factor system in uterine function and placental development in ruminants. $\mathrm{J}$ Dairy Sci 1998; 81, 1778-89.

225. Watson AJ, Westhusin ME, Winger QA. IGF paracrine and autocrine interactions between conceptus and oviduct. J. Reprod. Fertil. 1999; Suppl. 54, 303-15.

226. Wilkins JF, Fowler DG, Bindon BM, Piper LR, Hall DG, Fogarty NM. Measuring foetal loss with real-time scanning. Proc. Aust. Soc. Anim. Prod. 1984; 15: 768.

227. Wilkins JF, Croker KP. Embrionic wastage in ewes. In. Reproductive physiology of Merin4o sheep; concepts and consequences. Austr. School Agr., Univ. Western Austr. 1990; 13: 169-177. Addham C. M., Martin G. B. and Purvis I. W. Eds.

228. Williams $\mathrm{AH}$, Cumming IA. Inverse relationship between concentration of progesterone and nutrition in ewes. J Agr Sci 1982; 98, 517-522.

229. Wintenberger-Torres S, Flechon JE. Ultrastructural evolution of the trophoblast cells of the pre-implantation sheep blastocyst from day 8 to day 18. J. Anat. 1974; $118,143-53$. 
230. Wolff M, Gibbons A, Cueto M. Variaciones de la actividad ovárica a lo largo del año en ovejas Merino en Patagonia. 1992; Informe de plan de trabajo. EEA. INTA Bariloche.

231. Yang WC, Yang LG, Riaz H, Tang KQ, Chen L, Li SJ. Effects in cattle of genetic variation within the IGF1R gene on the superovulation performance and pregnancy rates after embryo transfer. Animal reproduction science, 2013; 143(1-4), 24-29.

232. Yoon SJ, Cha KY, Lee KA. Leptin receptors are down-regulated in uterine implantation sites compared to interimplantation sites. Molecular and cellular endocrinology 2005; 232(1-2), 27-35.

233. Zhang Y, Proenca R, Maffei M, Barone M, Leopold L, Friedman JM. Positional cloning of the mouse obese gene and its human homologue. Nature 1994; 372: 425432.

234. Zhang S, Blache D, Blackberry MA, Martin GB. Body reserves affect the reproductive endocrine responses to an acute change in nutrition in mature male sheep. Anim. Reprod. Sci. 2005; 88(3-4), 257-269. 


\section{BIOGRAFÍA PERSONAL}

La Veterinaria María Macarena Bruno Galarraga nació el 1 de octubre de 1984 en la ciudad de Tandil, provincia de Buenos Aires, Argentina. Realizó sus estudios secundarios en la Escuela Agrotécnica No1 Dr. Ramón Santamarina e ingreso a la Facultad de Ciencias Veterinarias de la UNCPBA en el año 2004 donde se desempeñó como ayudante alumno durante tres años en la cátedra de Enfermedades Infecciosas. En el 2010 contrajo matrimonio con Agustín Martínez, veterinario e investigador del grupo de Salud Animal del INTA Bariloche y se establecieron en la ciudad de San Carlos de Bariloche. En el año 2011 obtuvo el título de Veterinaria mediante la defensa de la tesina titulada "Recuperaciones embrionarias sucesivas en ovinos", luego de realizar una residencia de grado orientada a la investigación por 6 meses en el Grupo de Reproducción de Rumiantes Menores del INTA Bariloche. Durante el año 2012 siguió en colaboración con el grupo de reproducción de INTA y se desempeñó como auxiliar diplomado de la Cátedra de Reproducción Animal de la FCV de la UNLP. En el año 2013 obtuvo una beca del CONICET y desde entonces se desempeña como becaria en el Grupo de Reproducción Animal de la EEA Bariloche colaborando en actividades de investigación. Asimismo, durante estos años ha participado en grupos de gestión y proyectos de extensión y desarrollo territorial del INTA Bariloche. Obtuvo dos becas de movilidad de posgrado para realizar estancias de investigación, una en la Facultad de Agronomía de la UdeLaR (Beca AUGM, 2013) y en el INIA Madrid (Beca Fundación Carolina, 2019), especializándose en el área de reproducción animal. A su vez ha sido 
designada desde el año 2015 como Secretaria técnica del Comité regional para el uso y cuidado de animales de experimentación del Centro Regional Patagonia Norte del INTA (CICUAE-PATNOR). Por último, desde hace unos años ha estudiado la relación entre la nutrición y la reproducción en ovinos y caprinos, área en la que continuará trabajando una vez alcanzado el título de Doctor en Ciencias Veterinarias. 